Questa Baseline and Premining Ground-Water Quality Investigation 15 Methods of Phase II and III Well Installation and Development and Results of Well Logging, Hydraulic Testing, and Water-Level Measurements in the Red River Valley, New Mexico, 2002-04

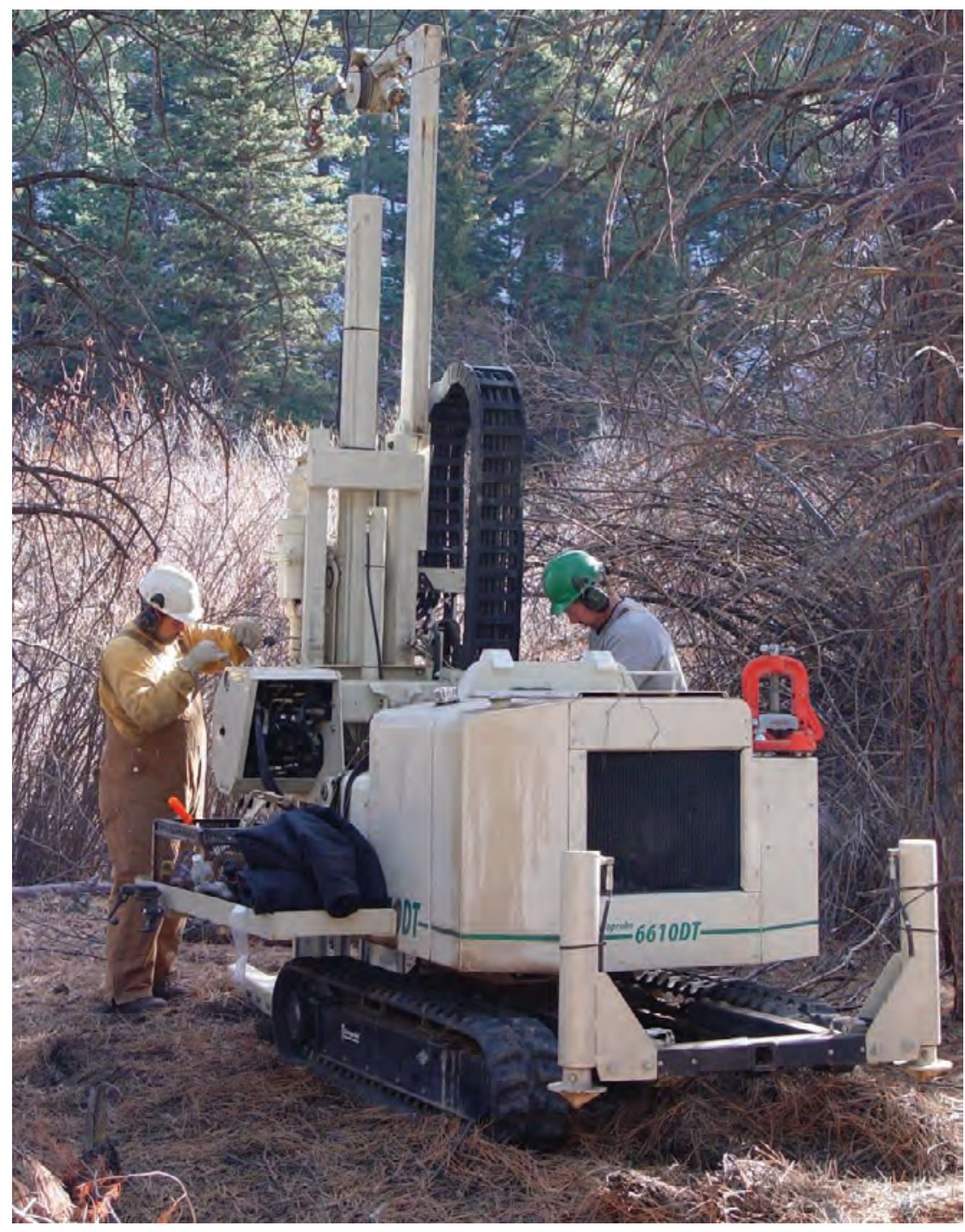

Scientific Investigations Report 2006-5246 

Questa Baseline and Pre-Mining Ground-Water Quality Investigation 15.

\section{Methods of Phase II and III Well Installation and Development and Results of Well Logging, Hydraulic Testing, and Water-Level Measurements in the Red River Valley, New Mexico, 2002-04}

By Paul J. Blanchard, James R. Bartolino, Lisa C. Donohoe, Douglas P. McAda, Cheryl A. Naus, and Roger H. Morin

Prepared in cooperation with the New Mexico Environment Department

Scientific Investigations Report 2006-5246 


\section{U.S. Department of the Interior DIRK KEMPTHORNE, Secretary}

\section{U.S. Geological Survey \\ Mark D. Myers, Director}

\section{U.S. Geological Survey, Reston, Virginia: 2007}

For product and ordering information:

World Wide Web: http://www.usgs.gov/pubprod

Telephone: 1-888-ASK-USGS

For more information on the USGS--the Federal source for science about the Earth, its natural and living resources, natural hazards, and the environment:

World Wide Web: http://www.usgs.gov

Telephone: 1-888-ASK-USGS

Any use of trade, product, or firm names is for descriptive purposes only and does not imply endorsement by the U.S. Government.

Although this report is in the public domain, permission must be secured from the individual copyright owners to reproduce any copyrighted materials contained within this report.

Suggested citation:

Blanchard, P.J., Bartolino, J.R., Donohoe, L.C., McAda, D.P., Naus, C.A., and Morin, R.H., 2007, Questa baseline and pre-mining ground-water quality investigation 15.-Methods of phase II and III well installation and development and results of well logging, hydraulic testing and water-level measurements in the Red River Valley, New Mexico, 2002-04: U.S. Geological Survey Scientific Investigations Report 2006-5246, 56 p.

Front cover: Jeffery Eman (left) and Arthur Clark (right), U.S. Geological Survey, Lakewood, Colorado, drilling shallow well near bank of Red River. Photograph taken by Cheryl Naus, U.S. Geological Survey, Albuquerque, New Mexico. 


\section{Contents}

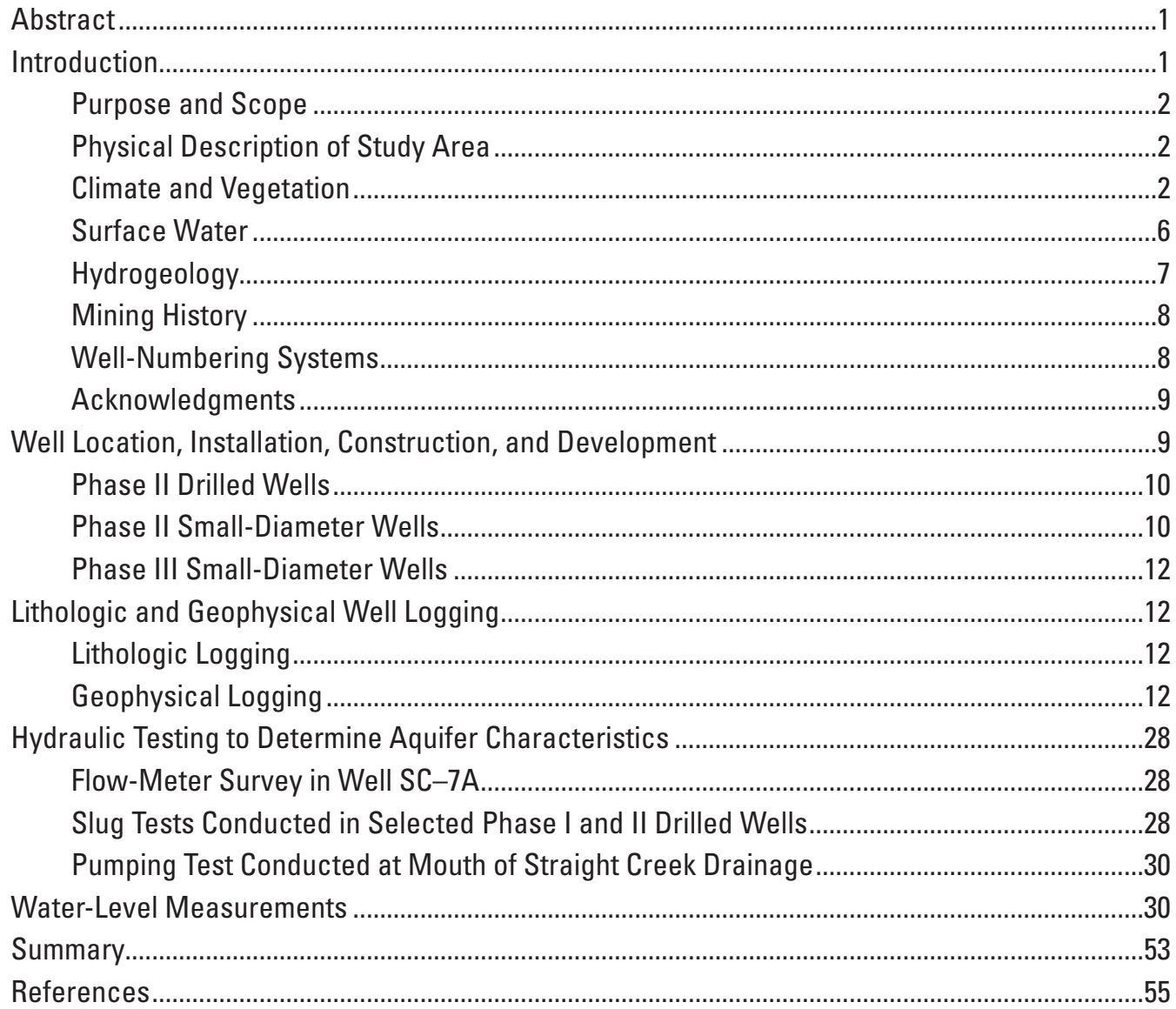

\section{Figures}

1-5. Maps showing location of:

1. Study area in Red River Valley, north-central New Mexico, and features of study

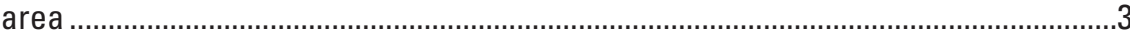

2. Hottentot well ........................................................................................................

3. Straight Creek and Advanced Wastewater Treatment Facility wells ........................5

4. La Bobita and Hansen Phase II wells and Phase III wells .......................................6

5. Capulin Canyon Phase II wells ............................................................................

6. Diagram showing well-numbering system in New Mexico..............................................9

7. Diagrams showing well-completion data and lithologic logs for Hottentot, Hansen,

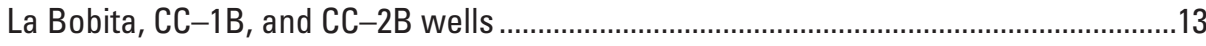

8. Diagrams showing well-completion data, lithologic logs, and geophysical logs for

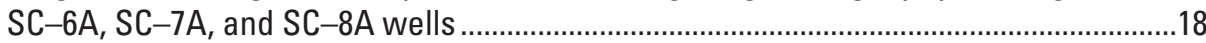

9. Diagram showing vertical distribution of borehole flow measured during pumping and corresponding percentage of flow into well SC-7A .........................................................29 
10-14. Graphs showing:

10. Water levels in wells AWWT-1, SC-5A, SC-5B, SC-7A, and SC-8A before, during, and after pumping test and comparison of water levels in well AWWT-2 to barometric pressure, November 22-December 5, 2003.........................................31

11. Daily mean streamflow and stage of the Red River near Questa and ground-water altitudes in wells SC-6A, SC-7A, and SC-8A, February 2003-June 2004.

12. Ground-water altitudes in Hottentot, Hansen, and La Bobita wells, February 2003-June 2004

13. Ground-water altitudes in wells $C C-1 A, C C-1 B, C C-2 A$, and $C C-2 B$, February 2003-April 2004.

14. Difference between ground-water altitudes in La Bobita and Phase III wells and altitude of water in Red River, May 13 and June 2-3, 2004

\section{Tables}

1. Locations, altitudes, construction information, and initial water levels for Phase II and III wells, Red River Valley, north-central New Mexico, 2002-04

2. Estimated hydraulic-conductivity values for slug tests conducted June 3-5, 2003, for selected wells in Red River Valley, north-central New Mexico

3. Results of pumping test conducted December 3-4, 2003, in selected wells in Red River Valley, north-central New Mexico

4. Altitude of water levels in Phase I, II, and existing Advanced Wastewater Treatment Facility wells, Red River Valley, north-central New Mexico, 2002-04.

5. Altitude of water levels in La Bobita and Phase III wells and concurrent altitude of stage of Red River, north-central New Mexico, 2003-04. 


\section{Conversion Factors and Datums}

\begin{tabular}{|c|c|c|}
\hline Multiply & By & To obtain \\
\hline \multicolumn{3}{|c|}{ Length } \\
\hline inch (in.) & 2.54 & centimeter (cm) \\
\hline foot $(\mathrm{ft})$ & 0.3048 & meter $(\mathrm{m})$ \\
\hline mile (mi) & 1.609 & kilometer (km) \\
\hline \multicolumn{3}{|c|}{ Area } \\
\hline acre & 4,047 & square meter $\left(\mathrm{m}^{2}\right)$ \\
\hline square foot $\left(\mathrm{ft}^{2}\right)$ & 0.0929 & square meter $\left(\mathrm{m}^{2}\right)$ \\
\hline square mile $\left(\mathrm{mi}^{2}\right)$ & 2.590 & square kilometer $\left(\mathrm{km}^{2}\right)$ \\
\hline \multicolumn{3}{|c|}{ Volume } \\
\hline gallon (gal) & 3.785 & liter (L) \\
\hline \multicolumn{3}{|c|}{ Flow Rate } \\
\hline foot per day $(\mathrm{ft} / \mathrm{d})$ & 0.3048 & meter per day $(\mathrm{m} / \mathrm{d})$ \\
\hline foot squared per day $\left(\mathrm{ft}^{2} / \mathrm{d}\right)$ & 0.09290 & meter squared per day $\left(\mathrm{m}^{2} / \mathrm{d}\right)$ \\
\hline foot squared per minute $\left(\mathrm{ft}^{2} / \mathrm{min}\right)$ & 0.09290 & meter squared per minute $\left(\mathrm{m}^{2} / \mathrm{min}\right)$ \\
\hline gallon per minute (gal/min) & 0.06309 & liter per second $(\mathrm{L} / \mathrm{s})$ \\
\hline cubic foot per second $\left(\mathrm{ft}^{3} / \mathrm{s}\right)$ & 0.02832 & cubic meter per second $\left(\mathrm{m}^{3} / \mathrm{s}\right)$ \\
\hline \multicolumn{3}{|c|}{ Mass } \\
\hline ton & 0.9072 & megagram \\
\hline
\end{tabular}

Ohm-meters (ohm-m) can be converted to microsiemens per centimeter $(\mu \mathrm{S} / \mathrm{cm})$ by the equation

$$
(1 / \mathrm{ohm}-\mathrm{m}) \times 0.0001=\mu \mathrm{S} / \mathrm{cm} \text {. }
$$

Temperature in degrees Celsius $\left({ }^{\circ} \mathrm{C}\right)$ may be converted to degrees Fahrenheit $\left({ }^{\circ} \mathrm{F}\right)$ as follows:

$$
{ }^{\circ} \mathrm{F}=\left(1.8 x^{\circ} \mathrm{C}\right)+32 .
$$

Temperature in degrees Fahrenheit $\left({ }^{\circ} \mathrm{F}\right)$ may be converted to degrees Celsius $\left({ }^{\circ} \mathrm{C}\right)$ as follows:

$$
{ }^{\circ} \mathrm{C}=\left({ }^{\circ} \mathrm{F}-32\right) / 1.8 \text {. }
$$

Vertical coordinate information is referenced to the National Geodetic Vertical Datum of 1929 (NGVD 29).

Horizontal coordinate information is referenced to the North American Datum of 1983 (NAD 83).

Altitude, as used in this report, refers to distance above the vertical datum. 


\title{
Questa Baseline and Pre-Mining Ground-Water Quality Investigation 15.-Methods of Phase II and III Well Installation and Development and Results of Well Logging, Hydraulic Testing, and Water-Level Measurements in the Red River Valley, New Mexico, 2002-04
}

\author{
By Paul J. Blanchard, James R. Bartolino, Lisa C. Donohoe, Douglas P. McAda, Cheryl A. Naus, and \\ Roger H. Morin
}

\section{Abstract}

In April 2001, the U.S. Geological Survey and the New Mexico Environment Department began a cooperative study to infer the pre-mining ground-water chemistry at the Molycorp molybdenum mine site in the Red River Valley of northcentral New Mexico. This report is one in a series of reports that can be used to determine pre-mining ground-water conditions at the mine site.

Weathering of hydrothermally altered bedrock in the study area has resulted in steep, highly erosive, and sparsely vegetated scar areas that are clearly visible from the ground and in aerial photographs. Runoff from intense summer rainfall over tributary drainages containing scar areas can transport large quantities of sediment and form debris fans where these tributaries join the Red River.

Twenty-nine observation wells were installed in three phases as part of this study in the Red River Valley and tributary drainages. Eight Phase II observation wells were drilled using an air-rotary/hammer rig. Three Phase II and 10 phase III small-diameter wells were installed using a direct-push rig. Lithologic logs were recorded for all eight Phase II drilled wells. Borehole geophysical logging (including natural gamma, induction, and single-detector neutron) was conducted in three Phase II wells.

Aquifer tests conducted during 2003 to estimate the hydraulic properties of debris-flow and Red River alluvial deposits in and near Straight Creek included a flow-meter survey, slug tests, and a pumping test. Results of a flow-meter survey in well SC-7A indicated that about 77 percent of the water entered the well from a 10-foot-thick zone near the top of the screened interval and about 23 percent of the water entered the well from a 15-foot-thick zone near the bottom of the screened interval. Slug tests, performed in 11 wells during June $3-5,2003$, indicated that the mean and median estimated hydraulic conductivities for debris-flow deposits were 15.25 and 15.35 feet per day, respectively, for bedrock were 0.12 and 0.08 feet per day, respectively, and for mixed debris flow and Red River alluvium were 73-207 (estimated range) and 80 feet per day. In general, bedrock has the smallest hydraulic conductivity, debris-flow material has the next highest hydraulic conductivity, and mixed debris flow and Red River alluvium has the largest hydraulic conductivity. A pumping test conducted December 3-4, 2003, using well AWWT-1 as the pumped well, and wells AWWT-2, SC-5A, SC-5B, SC-7A, and SC-8A as observation wells, indicated estimated transmissivity of 12,000 to 34,000 feet squared per day and estimated hydraulic conductivity of 230 to 340 feet per day.

Water-level measurements in wells SC-6A, SC-7A, SC-8A, and the Hottentot, Hansen, and La Bobita wells show that water levels typically rose rapidly during melting of the winter snowpack in the springtime and then generally declined during the rest of the year. The water-level rise in response to spring snowmelt occurred earlier and was smaller at larger distances from the Red River. Differences between the stage in the Red River and water levels in wells SC-8A and SC-9A, and the absence of water in well SC-9A at the time of well completion, indicate that the Red River has a poor hydraulic connection to the underlying ground-water system and the surface-water system is perched above the ground-water system at this site. Water levels in Phase III wells indicate that the Red River and the shallow ground-water system are connected hydraulically from near wells 4-1D and 4-1S downstream to near wells 2-1 and 2-2 but are poorly connected near the $\mathrm{La}$ Bobita well and well 1.

\section{Introduction}

In April 2001, the U.S. Geological Survey (USGS) and the New Mexico Environment Department began a cooperative study to infer the pre-mining ground-water chemistry at 
the Molycorp molybdenum mine site in the Red River Valley in north-central New Mexico (fig. 1). This study was prompted by the Water Quality Act, under the jurisdiction of the New Mexico Water Quality Control Commission that requires a mine operator to develop and complete an approved closure plan that prevents the exceedence of (1) standards set forth in New Mexico Water Quality Control Commission Regulations (\$20.6.2.3103 New Mexico Administrative Code) or (2) natural background water-constituent concentrations.

The Molycorp molybdenum mine has operated intermittently since the 1920s; ground-water-level and water-quality data were not obtained prior to initiation of mining. To infer pre-mining ground-water chemistry, observation wells were installed in three phases in unmined areas that were judged to be analogs to the mine site. During Phase I wells were installed in the Straight Creek drainage (Naus and others, 2005) and during phases II and III wells were installed in five additional areas. The five areas were Hottentot Creek, Straight Creek, Hansen Creek, near La Bobita campground, and Capulin Canyon. The Hottentot Creek, Straight Creek, and Hansen Creek drainages (figs. 1, 2, 3, and 4) contain debrisflow deposits associated with scar areas. The La Bobita (fig. 4) drainage contains unconsolidated deposits in a non-scar area characterized by propylitic alteration. Capulin Canyon (figs. 1 and 5) contains shallow unconsolidated deposits overlying bedrock in a non-scar area. The existing ground-water conditions in these five analog areas were used to establish baseline ground-water conditions which, when combined with groundwater conditions in mined areas, can be used to infer pre-mining conditions at the mine site.

Field observations indicated that the analog areas have been disturbed to varying degrees by non-mining anthropogenic activities. These activities include exploration drilling, road construction, power and telephone line construction and maintenance, forest service construction and maintenance, and residential, commercial, and municipal development. The Straight Creek drainage basin was selected as the primary ana$\log$ area because of similarities of terrain and geology to the mine site, its accessibility and potential for well installation, and minimal anthropogenic disturbance.

\section{Purpose and Scope}

The purpose of this report is to document and describe Phase II and Phase III well installation and development, present results of lithologic and geophysical logging, present results of hydraulic testing to determine aquifer characteristics, and present and discuss water-level measurements collected during the period March 2002 through June 2004. Because of the size and complexity of the study area, this report is one in a series of reports that can be used to determine pre-mining ground-water conditions at the mine site. The results of these studies can help guide decisionmakers in establishing appropriate remedial actions at the Molycorp mine.

\section{Physical Description of Study Area}

The Red River, a tributary to the Rio Grande, is located in north-central New Mexico (fig. 1). The area is a rugged mountainous terrain with steep slopes and V-shaped valleys. The main area of study within the Red River drainage basin extends west from the town of Red River to the USGS streamflow-gaging station near Questa (fig. 1) (station 08265000, Red River near Questa, New Mexico, referred to as the Questa gage). The area upstream from the Questa gage includes approximately $18 \mathrm{mi}$ (miles) of the Red River and $108 \mathrm{mi}^{2}$ (square miles) of the Red River drainage basin. The mine site is located east of the Questa ranger station to the north of the Red River and New Mexico State Highway 38 (fig. 1). The mine site covers approximately $6 \mathrm{mi}^{2}$ (U.S. Department of Agriculture Forest Service, 2001) and includes three primary tributary drainages to the Red River-Capulin Canyon, Goat Hill Gulch, and Sulphur Gulch (fig. 1).

Hydrothermally altered bedrock is present in the Hottentot, Straight, Hansen, Little Hansen, Goat Hill, Sulphur, and Capulin drainages (fig. 1). Weathering of this bedrock has resulted in steep, highly erosive, and sparsely vegetated scar areas that are clearly visible from the ground and in aerial photographs.

Mining activities have produced extensive underground workings and an open pit of approximately 162 acres (Naus and others, 2005) in and adjacent to Sulphur Gulch. Wasterock piles cover steep slopes on the north side of the Red River Valley between Capulin Canyon and Spring Gulch, a tributary valley of Sulphur Gulch.

\section{Climate and Vegetation}

The Red River drainage basin is located within a semiarid desert that receives precipitation throughout the year and sustains moderate biodiversity. Between 1915 and 2002, the annual average temperature at the town of Red River was $4{ }^{\circ} \mathrm{C}$, and the annual average precipitation and snowfall were approximately 20.5 and 146 in. (inch), respectively. The annual range of average daily temperatures at Red River was $18{ }^{\circ} \mathrm{C}$ (Western Regional Climate Center, 2003).

Climate and vegetation vary greatly within short distances, primarily because of differences in topography. Topography in the study area is steep, rising rapidly from the basinfloor elevation of approximately 7,450 ft (feet) at the Questa gage to ridge-crest elevations exceeding 10,500 ft. Orographic effects of mountainous topography lead to precipitation on the windward slopes and localized storms within the Red River drainage basin and tributary drainages. Precipitation from intense summer storms can cause soil mass wasting and debris flows in the scar areas that result in debris-flow deposits and debris fans at the mouths of many tributaries to the Red River (Kirk Vincent, USGS, written commun., 2003).

Dominant vegetation associations in the Red River Basin and the general elevation zones are piñon-juniper woodland 


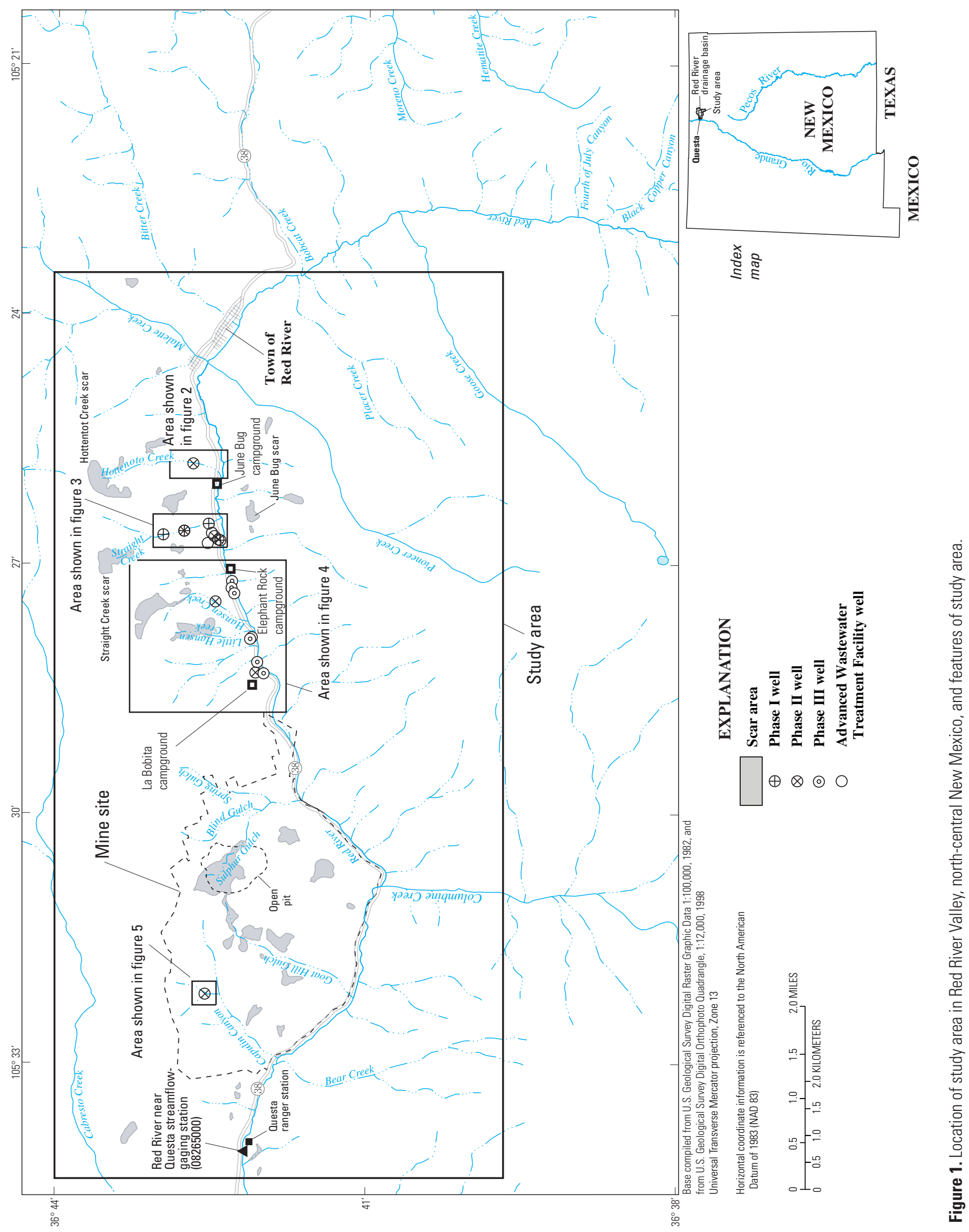




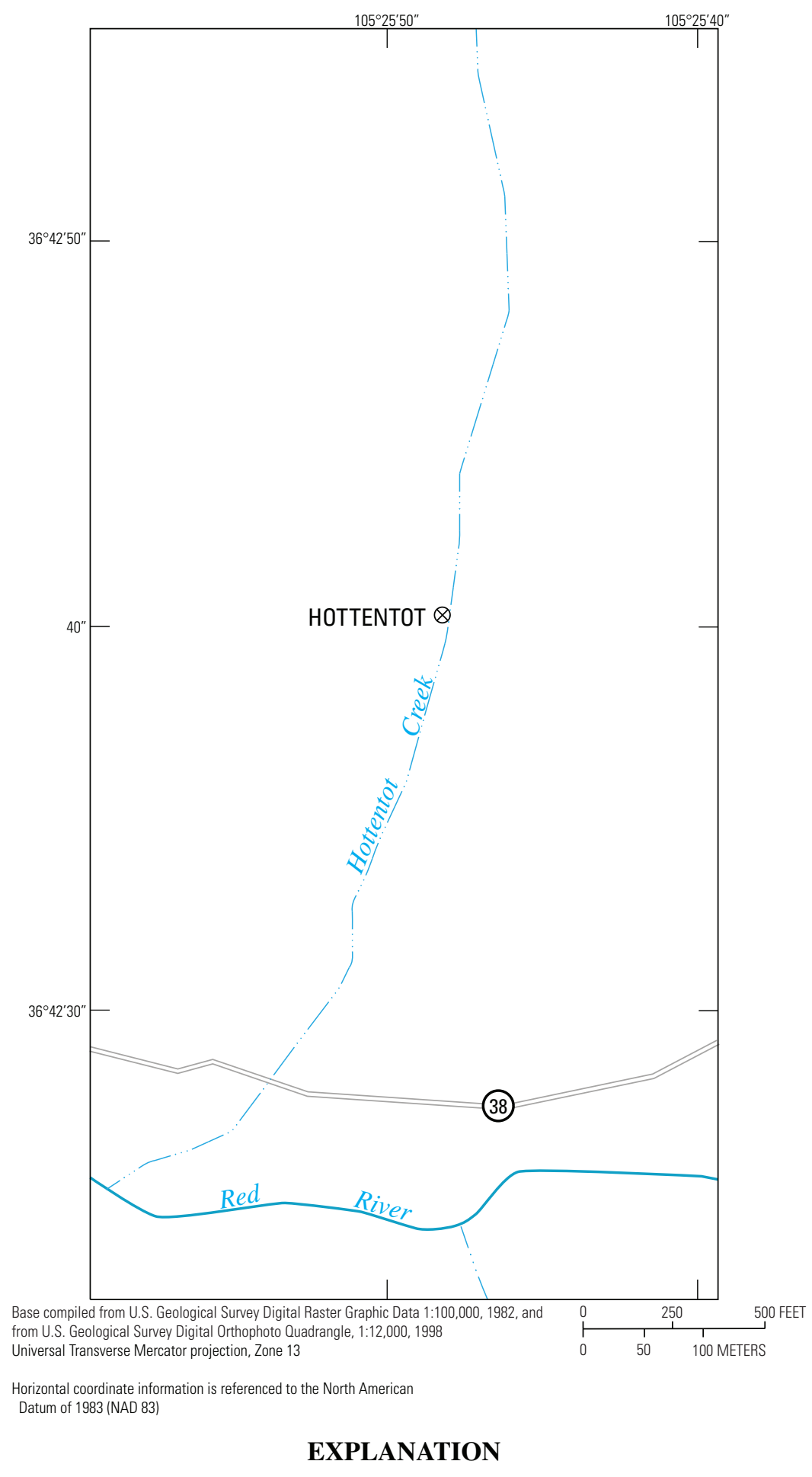

HOTTENTOT $\otimes$ Phase II well and name

Figure 2. Location of Hottentot well. 


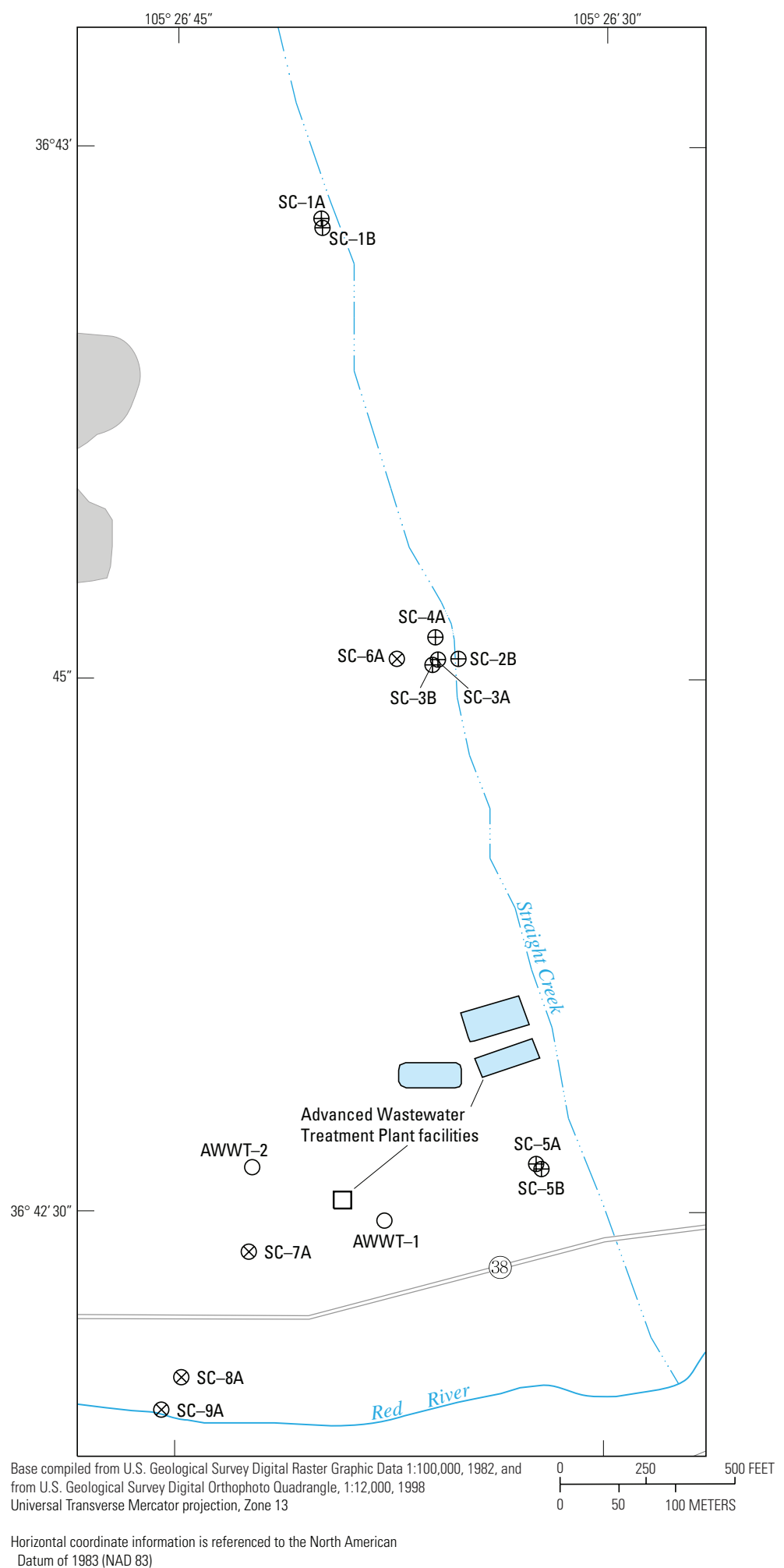

EXPLANATION

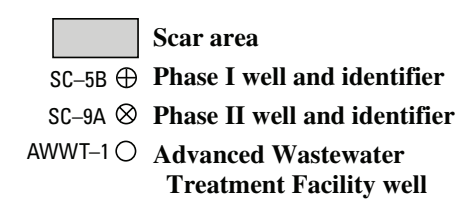

Figure 3. Location of Straight Creek and Advanced Wastewater Treatment Facility wells. 


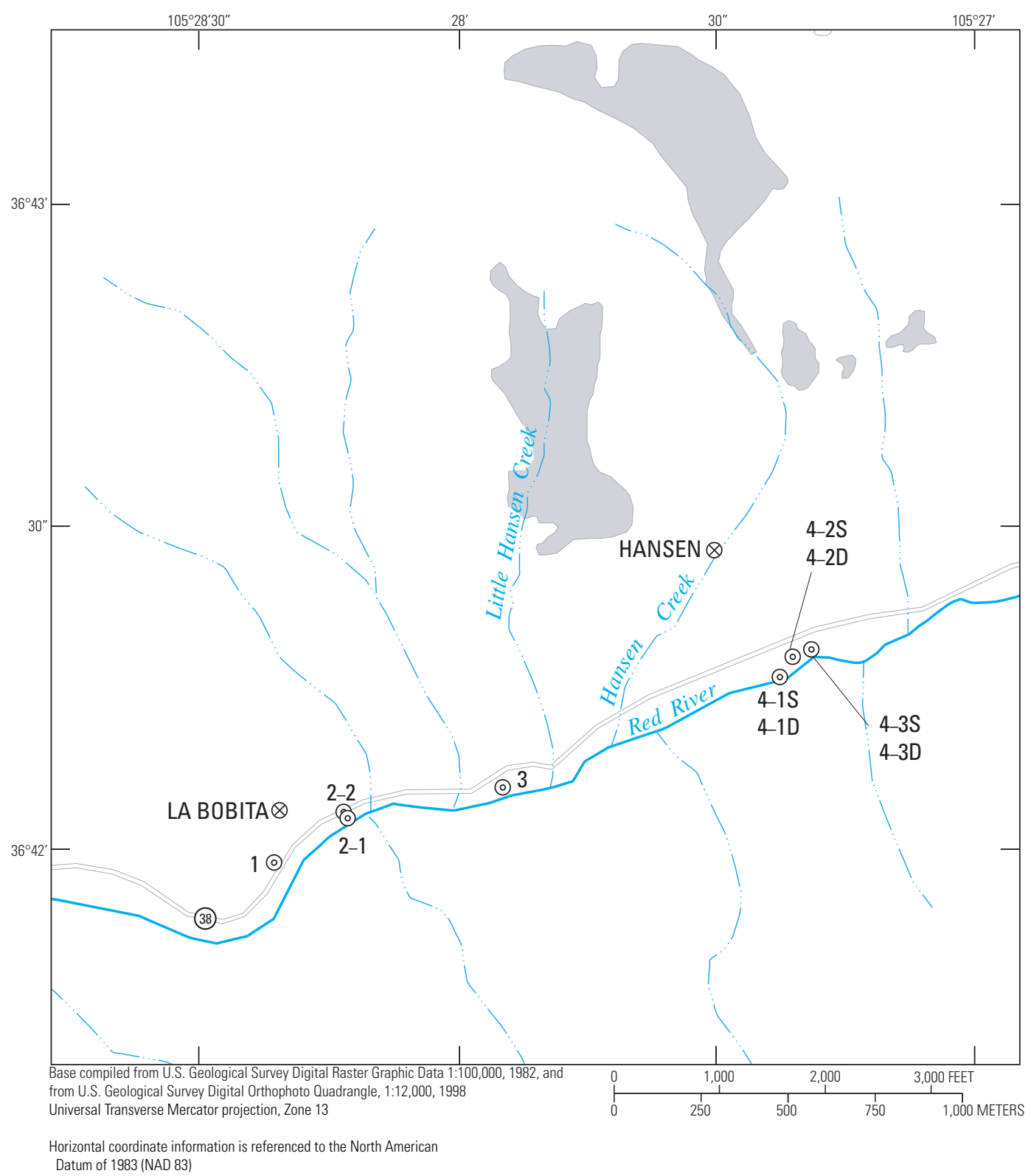

\section{EXPLANATION}

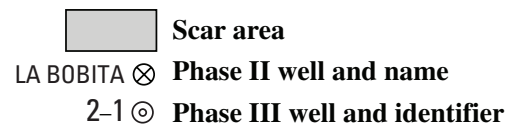

Figure 4. Location of La Bobita and Hansen Phase II wells and Phase III wells.

from 6,000 to 7,500 ft, mixed conifer woodland (primarily ponderosa and limber pine) from 7,500 to $9,000 \mathrm{ft}$, and spruce-fir woodland (primarily Douglas and white fir) from 9,000 to 12,000 ft (Knight, 1990; Larry Gough, USGS, oral commun., 2003).

\section{Surface Water}

The Red River originates at an altitude of about 12,000 ft, flows about $35 \mathrm{mi}$, and enters the Rio Grande at about
6,600 ft. The total Red River drainage-basin area is $190 \mathrm{mi}^{2}$; the drainage area upstream from the Questa gage is $108 \mathrm{mi}^{2}$. Snowmelt flows typically begin in late March and peak in late May to mid-June. Summer thunderstorms are prevalent in July and August and can cause localized flooding and debrisflow movement. Between 1930 and 2001, the mean annual discharge of the Red River at the Questa gage ranged from 12.8 to $103 \mathrm{ft}^{3} / \mathrm{s}$ (cubic feet per second), the average daily discharge ranged from 2.5 to $750 \mathrm{ft}^{3} / \mathrm{s}$, and the average discharge was $46.1 \mathrm{ft}^{3} / \mathrm{s}$ (U.S. Geological Survey, 2004). 


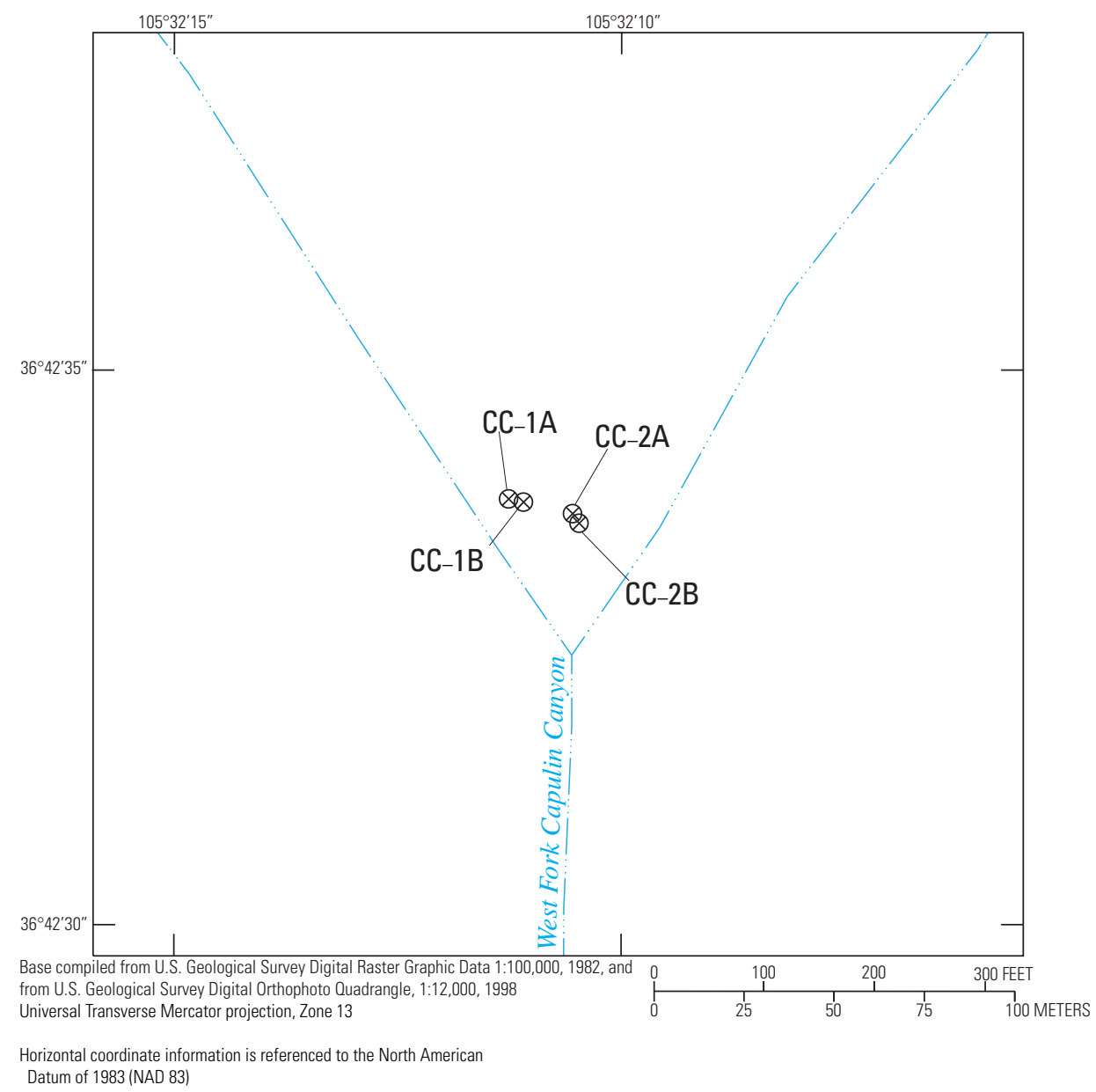

EXPLANATION

$C C-1 B \otimes$ Phase II well and identifier

Figure 5. Location of Capulin Canyon Phase II wells.

Springs and shallow alluvial ground water discharge to the Red River, making the river a gaining stream over much of its length (Smolka and Tague, 1989). Between the town of Red River and the Questa gage, there are about 25 ephemeral seeps and springs along the banks of the Red River and approximately 20 intermittent seeps and springs in tributary drainages on the north side of the river (South Pass Resources, Inc., 1995; Steffen, Robertson, \& Kirsten, 1995; Robertson GeoConsultants, Inc., 2001). Flow from these springs and seeps affect the color and turbidity of the river. Aluminum hydroxide often precipitates downgradient from scar and mined areas on the north side of the Red River (Vail Engineering, Inc., 1989).

In the Straight Creek drainage, the West Fork of Straight Creek flows perennially through most of its reach. The East Fork of Straight Creek and Straight Creek downstream from the confluence of the West and East Forks flow ephemerally and intermittently; streamflow typically infiltrates the debrisflow deposits upstream from this confluence. Streamflow in Straight Creek discharges to the Red River only during periods of peak snowmelt runoff and following intense precipitation.
The downstream reach of the Straight Creek natural streambed has been reworked to divert flow around the east side of the Advanced Wastewater Treatment (AWWT) Facility, which is operated by the town of Red River.

\section{Hydrogeology}

This section describes the generalized geology, geomorphology, and water-bearing units in the Red River Valley. Previous studies of the geology and mineralogy of the Red River Valley include those by Schilling (1956), Rehrig (1969), Lipman (1981), and Meyer and Leonardson (1990, 1997). The following discussion uses information from these sources, from Ludington and others (2005), and from USGS scientists participating in this study.

The Red River Valley is located along the southern edge of the Questa Caldera and contains complex structural features (Caine, 2003) and extensive zones of hydrothermal alteration. The geology of the basin consists of volcanic and intrusive rocks of Tertiary age, underlain by metamorphic rocks of 
Precambrian age that were intruded by granitic stocks. The volcanic rocks are primarily intermediate to felsic in composition (andesite to rhyolite). Granites and porphyries that intruded the volcanic rocks were the apparent source of the hydrothermal fluids, rock alteration, and subsequent mineralization. Mineral deposits in the Red River Valley are considered climax-type deposits, which are associated with silicaand fluorine-rich rhyolite porphyry and granitic intrusives.

Ore deposits in the Red River Valley contain quartz, molybdenite, pyrite, fluorite, calcite, manganiferous calcite, dolomite, ankerite, and rhodochrosite. Lesser amounts of galena, sphalerite, chalcopyrite, magnetite, and hematite also are present. The hydrothermal alteration related to mineralization overprints an older, regional alteration of rock. In these areas, rocks can contain a mixture of quartz, pyrite, and illite clays replacing feldspar, chlorite, carbonates, and epidote. Minerals occurring in waste rock produced by mining activities include chlorite, gypsum, illite, illite-smectite, jarosite, kaolinite, and muscovite (Gale and Thompson, 2001).

Scar-area bedrock outcrops consist of andesitic volcanic and volcaniclastic rocks, rhyolitic tuff, quartz latite, and rhyolite porphyry. Most of the andesite and quartz latite has been hydrothermally altered and primarily contains plagioclase feldspar and chlorite. Rhyolite porphyry and tuff do not seem to have been substantially altered.

Runoff from intense summer rainfall over basins tributary to the Red River can transport large quantities of sediment down tributary drainages and form debris fans where these tributaries join the Red River. Where the tributary drainages contain scar areas, the debris fans are large, indicate evidence of active deposition, and contain poorly sorted coarse gravel and cobble to clay-size sediments. Sediment transported and deposited by the Red River (Red River alluvium), in contrast, generally consists of medium- to well-sorted sand and gravel that consist of a mix of the bedrock lithologies found in the entire Red River drainage basin. Large debris fans debouching from tributary drainages have caused aggradation of the Red River streambed in river reaches upstream from debris fans (Kirk Vincent, USGS, written commun., 2005).

Important water-bearing units in the Red River Valley include fractured bedrock, debris-flow deposits, and Red River alluvium. Bedrock constitutes the largest aquifer in the study area in terms of rock mass but contains only small amounts of ground water because the rock has low porosity and most of the water occurs in fractures. Debris-flow deposits, debris fans, and Red River alluvium are smaller in area, but they contain most of the ground water in the valley. Debris-flow deposits, debris fans, and the Red River alluvium typically are less than 1,000 ft wide and less than $200 \mathrm{ft}$ thick (Kirk Vincent, USGS, written commun., 2003). The largest debris fans have caused the Red River to aggrade upstream from the fans during the Quaternary; water flowing in these shallow aquifers likely passes alternately through Red River alluvium and debris-flow deposits (Kirk Vincent, USGS, written commun., 2003).

\section{Mining History}

Molybdenite was discovered in Sulphur Gulch in 1914. Subsequently, underground mining operations took place between 1919 and 1958; by 1954 there were more than $35 \mathrm{mi}$ of underground mine workings (Robertson Geoconsultants, 2000c; U.S. Environmental Protection Agency, 2000). Exploration of areas surrounding the mine was conducted following closure of the mine in 1958. By 1964, sufficient reserves had been identified to justify development of an open-pit mine in Sulphur Gulch and construction of a mill capable of processing 10,000 tons of ore per day. The first ore from the pit was delivered to the mill in December 1965 (Molycorp, Inc., 2004).

Overburden and waste rock from open-pit mining was deposited at several locations on the south-facing slopes north of the Red River between Capulin Canyon and Spring Gulch (Robertson Geoconsultants, 2000a, 2000c; URS, 2001). Beginning in 1964, tailings were transported by pipeline from the mine to the tailings facility near Questa. Water used in the mill operation was obtained from the Red River, the Red River alluvium, and from water collected during dewatering of the mine (URS, 2002). Approximately 328 million tons of waste rock were deposited at the tailings facility between 1964 and 1983 (Steffen Robertson \& Kirsten, 1995; Slifer, 1996; Robertson GeoConsultants, Inc., 2000b, 2000c).

Molycorp ceased open-pit mining in 1983 and initiated a new phase of underground mining in Goat Hill Gulch. This change effectively stopped the dumping of waste rock in Capulin Canyon; along the north slope of the Red River; and in Goat Hill, Sulphur, and Spring Gulches. It also increased the volume of tailings slurry transported by pipeline to the tailings facility.

While the underground mine was inactive during 1992-95, ground water was not pumped from the underground mine workings, and the workings were allowed to partially reflood. The mine was dewatered and repaired when production resumed in late 1996, and mining of a new ore body began in 1998 (Molycorp, Inc., 2004).

\section{Well-Numbering Systems}

Two systems of numbering wells were used in this study - a study-specific system and a standardized New Mexico system. In the study-specific system, wells in Capulin Canyon and Straight Creek were assigned a two-letter abbreviation designating the drainage in which the wells were located (CC and SC), a sequence number, and a suffix of $\mathrm{A}$ if the well was completed in unconsolidated debris-flow or alluvial deposits, or a suffix of B if the well was completed in bedrock. The sequence number identifies a single well completed in either unconsolidated deposits or bedrock or a pair of wells where one well was completed in unconsolidated deposits and one well was completed in bedrock. For example, well SC-7A designates a well in Straight Creek completed in 
unconsolidated debris-flow or alluvial deposits, SC-2B designates a well in Straight Creek completed in bedrock, and wells SC-5A and SC-5B designate a well pair in Straight Creek completed in debris-flow/alluvial deposits and bedrock, respectively.

In the study-specific system, Phase III wells were assigned a general site area (areas 1 through 4 ) in a downstream-to-upstream direction along the Red River. In areas 1 and 3, only one well was drilled; each well was designated 1 and 3, respectively. In area 2, two wells were drilled at different distances from the Red River and were designated 2-1 and 2-2. In area 4, three pairs of deep (D) and shallow (S) wells were drilled and designated 4-1D and 4-1S, 4-2D and 4-2S, and 4-3D and 4-3S.

The standardized system of numbering wells in New Mexico also was used to designate the location of wells in this report. The system is based on the common division of public lands into sections (fig. 6). The well number, in addition to designating the well, locates the position to the nearest 10-acre tract in the land network. This number is divided into four segments. The first segment denotes the township (T.) north (N.) or south (S.) of the New Mexico base line, the second denotes the range (R.) east (E.) or west (W.) of the New Mexico principal meridian, and the third denotes the section. The fourth segment of the number consists of three digits that denote section subdivisions of 160-, 40-, and 10-acre tracts, respectively. Each section is divided into four 160 -acre quarter sections. The first digit of the fourth segment denotes the quarter section and is numbered 1,2,3, or 4, for the northwest, northeast,

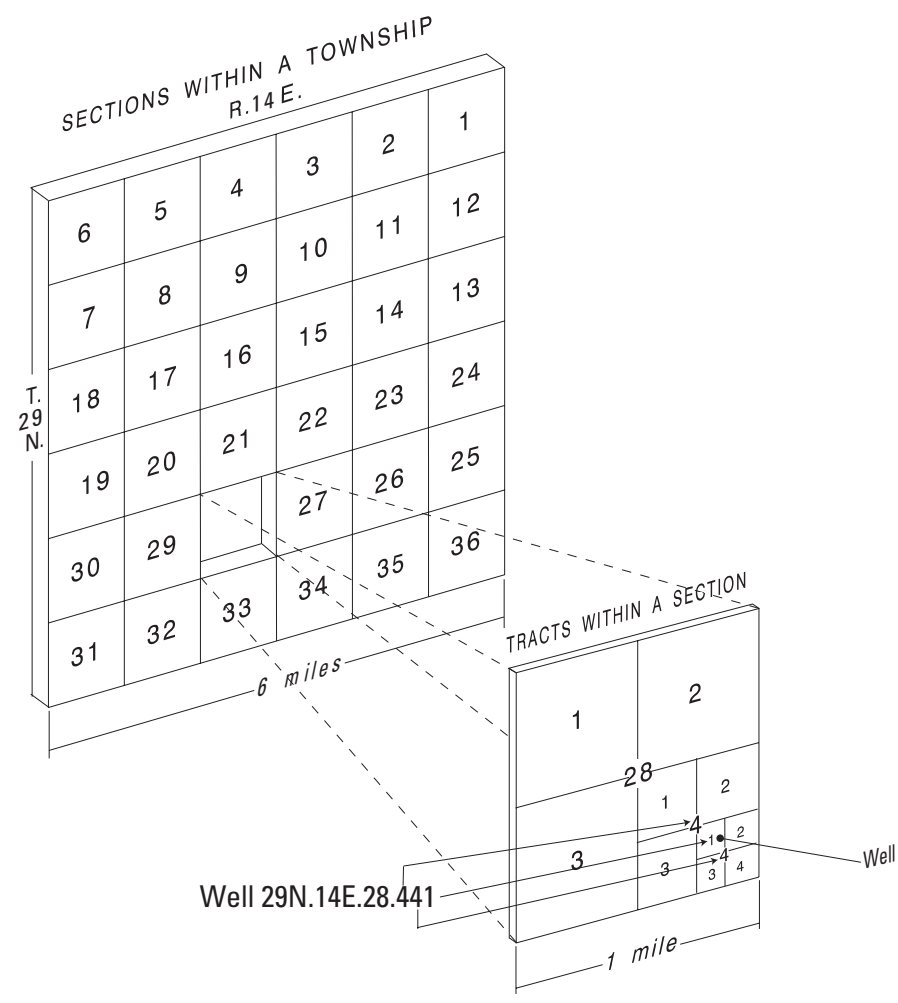

Figure 6. Well-numbering system in New Mexico. southwest, and southeast quarters. Similarly, each 160 -acre quarter section is further divided into four 40 -acre tracts numbered in the same manner, and the second digit denotes the 40 -acre tract. Finally, each 40 -acre tract is divided into four 10-acre tracts also numbered in the same manner, and the third digit denotes the 10-acre tract. Letters A, B, C, and so on are added sequentially to the fourth segment to designate the second, third, fourth, and succeeding wells in the same 10-acre tract. Well SC-1A, for example, is numbered 29N.14E.28.441 and, therefore, is in the $\mathrm{NW}^{1 / 4}$ of the $\mathrm{SE}^{1 / 4}$ of the $\mathrm{SE}^{1 / 4}$ of section 28 , township 29 north, range 14 east.

\section{Acknowledgments}

The authors thank the study Advisory Committee for their contributions to the design and implementation of the study. Advisory committee members included Amigos Bravos, Molycorp, and the New Mexico Environment Department. Advice and cooperation from the U.S. Environmental Protection Agency Region 6 and the U.S. Forest Service are gratefully acknowledged. The authors thank Russell Church, Plant Supervisor, AWWT facility, the town of Red River, and the AWWT facility staff for providing access to their observation wells and assisting with field activity logistics. Assistance with data compilation and sample collection by Caroline Myer (USGS) is greatly appreciated.

\section{Well Location, Installation, Construction, and Development}

Twenty-nine observation wells were installed in three phases as part of this study in the Red River Valley and tributary drainages (figs. 2-5). Eight observation wells were installed in the Straight Creek analog site during Phase I (November 2001 through February 2002) (Naus and others, 2005). Eleven additional wells were installed in the Hottentot, Straight, Hansen, La Bobita, and Capulin drainages during Phase II (October 2002 through January 2003). Ten small-diameter wells were installed in the Red River alluvium north of the Red River during Phase III (December 2003). Two existing wells (AWWT-1 and AWWT-2) at the town of Red River Advanced Wastewater Treatment Facility also were included in the monitoring-well network.

Phase I wells ( $\mathrm{SC}-1 \mathrm{~A}$ and $\mathrm{B}, \mathrm{SC}-2 \mathrm{~B}, \mathrm{SC}-3 \mathrm{~A}$ and $\mathrm{B}$, $\mathrm{SC}-4 \mathrm{~A}, \mathrm{SC}-5 \mathrm{~A}$ and B) were located in the Straight Creek drainage basin along the assumed path of ground-water flow in debris-flow deposits from the upstream part of the basin to near the mouth of the basin where straight Creek flows into Red River (fig. 3) (Naus and others, 2005). Wells SC-2B, $\mathrm{SC}-3 \mathrm{~A}, \mathrm{SC}-3 \mathrm{~B}$, and $\mathrm{SC}-4 \mathrm{~A}$ were located approximately midway between upgradient wells $\mathrm{SC}-1 \mathrm{~A}$ and $\mathrm{SC}-1 \mathrm{~B}$ and downgradient wells SC-5A and SC-5B. 
During Phase II, well SC-6A was installed west of the middle cluster of wells in the Straight Creek drainage to monitor ground-water conditions where results of a geophysical cross-section survey indicated that the debris-flow deposits were the thickest. Wells SC-7A and $\mathrm{SC}-8 \mathrm{~A}$ were installed in the Red River alluvial deposits west of Straight Creek in an area postulated to be a mixing zone of Straight Creek and Red River ground water (fig. 3). Well SC-7A was screened across an interval of approximately $90 \mathrm{ft}$ to compare water chemistry at selected depths within this postulated mixing zone. Comparison of water chemistry in samples from wells SC-7A and SC-8A is anticipated to aid in characterizing the mixing of acidic water from the debris fan near the mouth of Straight Creek with near-neutral pH water in the Red River alluvium. Well SC-9A was installed on the north bank of the Red River to complete the series of wells in the Straight Creek drainage basin and to monitor conditions at the ground-water/Red River interface.

The Hottentot, Hansen, and La Bobita wells were installed in debris-flow deposits to monitor ground-water conditions at these analog sites. The Capulin Canyon wells were installed to monitor ground-water conditions at an analog site without debris-flow deposits.

Phase III wells were installed in unconsolidated material along an approximately 1-mi reach of the Red River west of Elephant Rock campground (fig. 1). These wells were installed to examine the interaction of the Red River and water in the Red River alluvium.

Well locations and altitudes, construction information, and initial ground-water-level measurements for Phase II and Phase III wells are listed in table 1. Latitudes, longitudes, and altitudes of Phase II wells were determined by Molycorp using a Trimble 5800 Real Time Kinematic Rover ${ }^{\mathrm{TM}}$ with a Trimble 5700 Global Positioning System (GPS) Total Station ${ }^{\mathrm{TM}}$ base; accuracy of the system is $\pm 0.016 \mathrm{ft}$ horizontally and $\pm 0.1 \mathrm{ft}$ vertically (B.M. Walker, Molycorp, written commun(s)., 2003).

Latitudes and longitudes for Phase III wells were determined using a Garmin eTrex ${ }^{\circledR} 12$-parallel-channel GPS receiver; horizontal accuracy is $\pm 20 \mathrm{ft}$. The altitude of well AWWT-1 was estimated by using a hand-held site level and the altitude of the previously surveyed SC-7A well. The altitude of well AWWT-2 was determined from a USGS 71/2-minute (1:24,000-scale) topographic map. Altitudes of Phase III wells 1, 2-1, 2-2, and 3 were determined by a level survey from the previously surveyed Phase II La Bobita well (fig. 4). Altitudes of Phase III wells-4-1D, 4-SD, 4-2D, 4-2S, 4-3D, and 4-3S-were determined by estimation of the altitude of well 4-1D from a USGS 71/2-minute topographic map and a level survey from well 4-1D to the other five wells.

\section{Phase II Drilled Wells}

WDC Drilling Company (formerly THF Drilling Company) of Phoenix, Arizona, under direction of Souder, Miller and Associates (SMA) hydrogeologists and USGS hydrologists, drilled, constructed, and developed 8 of the 11 Phase II observation wells. These wells included the Hottentot well; Straight Creek wells SC-6A, SC-7A, and SC-8A; the Hansen well; the La Bobita well; and Capulin Canyon wells $\mathrm{CC}-1 \mathrm{~B}$ and $\mathrm{CC}-2 \mathrm{~B}$. The locations of these wells are shown in figures $2-5$, and information describing well location and construction is listed in table 1 .

All eight wells were drilled using an Ingersoll Rand TH75E air-rotary/hammer rig equipped with a Stratex ${ }^{\circledR}$ casing-advance system and an onboard Ingersoll Rand air compressor (an auxiliary compressor provided additional air capacity as needed). Boreholes were drilled using a 9-in. diameter button bit. Boreholes were advanced to total well depth using the Stratex ${ }^{\circledR}$ system to temporarily case the holes to ensure that the holes did not collapse. The temporary casing was cleaned using phosphate-free detergent and tapwater prior to drilling each well.

Each of the eight wells was constructed using new, flush-threaded, 4-in. diameter, schedule-80 polyvinyl chloride (PVC) casing and factory-cut, 0.010-in. slot-size PVC screen with threaded end cap. The annulus of each well was filled with 10/20 silica sand from the bottom of the hole to a minimum of $2.5 \mathrm{ft}$ above the top of the screen. A hydrated bentonite-pellet seal, typically from 4 to $8 \mathrm{ft}$ thick, was installed above the 10/20 silica sand, and hydrated bentonite chips were installed above the seal to the land surface.

Each of the eight wells was developed until specific conductance, $\mathrm{pH}$, and temperature stabilized. Stabilization criteria were: specific conductance, \pm 10 percent; $\mathrm{pH}$, \pm 0.1 standard unit; and temperature, $\pm 0.5^{\circ} \mathrm{C}$. Each well was initially developed by mechanical surging for a minimum of 20 minutes. Wells $\mathrm{CC}-1 \mathrm{~B}$ and $\mathrm{CC}-2 \mathrm{~B}$ were further developed by additional surging and subsequent pumping. Wells SC-6A, SC-8A, and the Hottentot, Hansen, and La Bobita wells were further developed by mechanical surging and subsequent bailing; wells SC-6A, SC-8A, and the Hottentot well were further developed by pumping following bailing. Well SC-7A was further developed solely by pumping.

\section{Phase II Small-Diameter Wells}

Phase II small-diameter wells were installed using a Geoprobe Model 6610-DT. The Geoprobe (a direct-push rig) uses hydraulic pressure and supplementary hammering to advance the drill point and drill rod. Wells $\mathrm{CC}-1 \mathrm{~A}$ and $\mathrm{CC}-2 \mathrm{~A}$ were installed in Capulin Canyon (fig. 5) next to the air-rotarydrilled wells CC-1B and CC-2B, respectively. Well SC-9A (fig. 3) was installed at the mouth of the Straight Creek drainage near the upstream end of the Elephant Rock campground (fig. 1). Prior to installing the SC-9A well casing, three smalldiameter, vertical holes were advanced to between 20 and $36 \mathrm{ft}$ below land surface along the north bank of the Red River in an attempt to locate the water table. All three holes were dry. A fourth small-diameter hole (well SC-9A) was advanced 


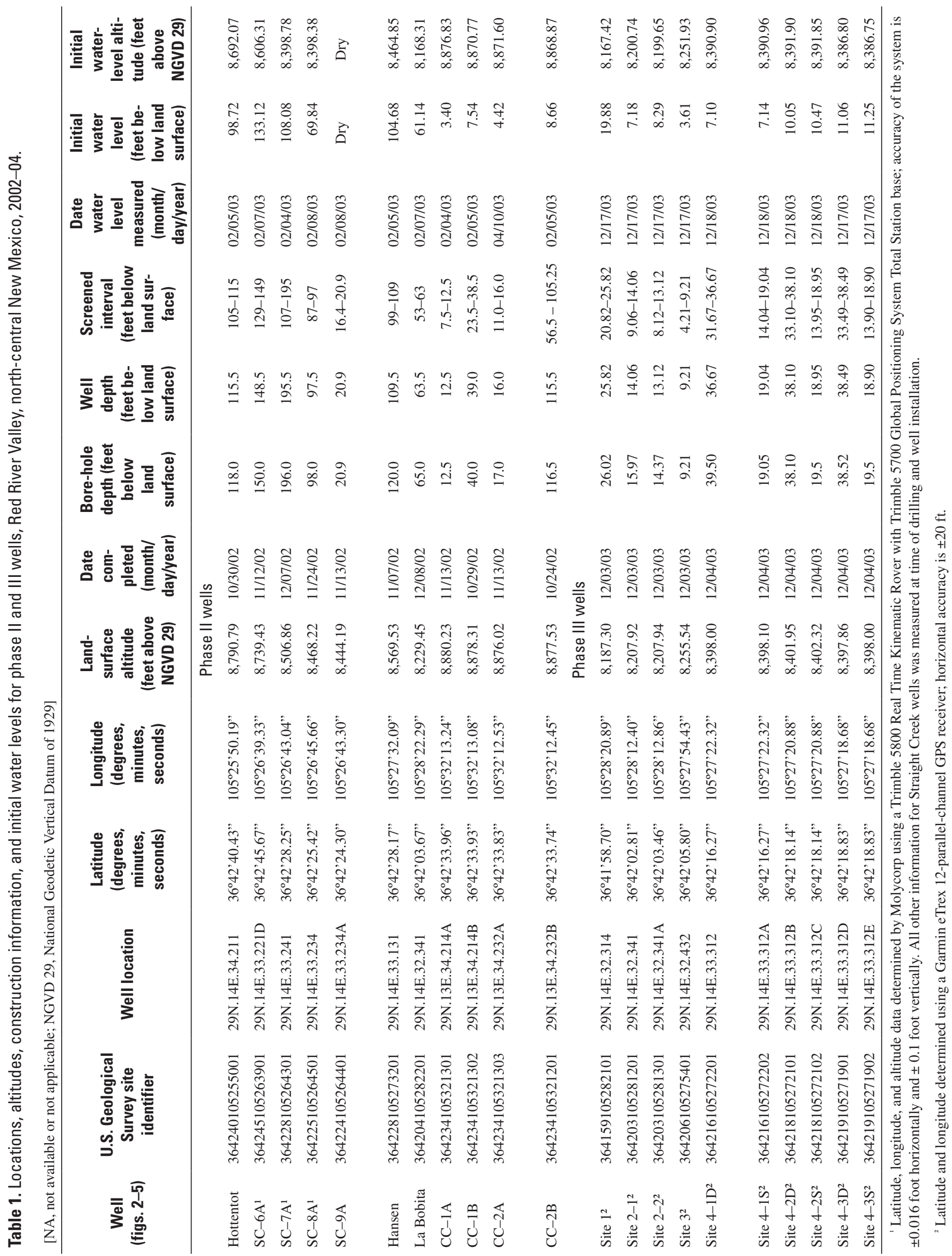


under the Red River at an angle of 21.5 degrees from vertical to a total angular depth of $22.5 \mathrm{ft}$. The vertical depth below land surface of this well is $20.9 \mathrm{ft}$ and the bottom of the well is about $1.3 \mathrm{ft}$ beyond the bank of the river. Well SC-9A also was dry at the time of installation.

Each of the Phase II small-diameter wells (CC-1A, CC-2A, and SC-9A) was completed by installing a 5-ft long, 1-in. diameter schedule 40 PVC factory-cut, 0.010-in. slot-size screen with a bottom cap at the total depth of the hole and 1in. diameter schedule 40 PVC casing above the slotted-screen section to approximately $2 \mathrm{ft}$ above land surface. The annulus of each well was filled with 10/20 silica sand from total depth to within about $5 \mathrm{ft}$ of land surface, above which the annulus was filled with 3/8-in. bentonite pellets to the land surface.

Wells CC-1A and CC-2A were surged for 15 and 50 minutes, respectively, and then purged until dry using a bailer or a peristaltic pump and dedicated tubing, after which the wells were allowed to recover. This purging and recovery sequence was conducted three times in each well. Well SC-9A was not developed because it was dry at the time of installation.

\section{Phase III Small-Diameter Wells}

Several facts, including well SC-9A being dry at completion, results of two synoptic tracer studies (McCleskey and others, 2003), and results of geomorphologic investigations (Kirk Vincent, USGS, written commun., 2005), suggested that from Straight Creek to about 1,500 ft upstream from Hansen Creek, surface water in the Red River and the underlying ground water in the Red River alluvium are hydraulically disconnected. In this area, ground water originating in debrisflow deposits likely flows into the Red River alluvial aquifer and remains in the subsurface hydraulically disconnected from the Red River. Ten small-diameter observation wells were installed along approximately a 1-mi reach of the Red River west of Elephant Rock campground to measure water levels to characterize ground-water flow along this reach of the Red River (fig. 4).

Ten Phase III wells were completed by installing a $5-\mathrm{ft}$ long, 1-in. diameter schedule 40 PVC factory-cut, 0.010-in. slot-size screen with a bottom cap at total depth of the hole and 1-in. diameter schedule 40 PVC casing above the slottedscreen section to approximately $2 \mathrm{ft}$ above land surface. The annulus of each well was filled with 10/20 silica sand from total depth to within about $5 \mathrm{ft}$ of land surface, above which the annulus was filled with $3 / 8$-in. bentonite pellets to the land surface. The wells were developed by pumping a minimum of three casing volumes of water from each well using a peristaltic pump and dedicated tubing. Specific conductance, $\mathrm{pH}$, temperature, and turbidity were monitored during development.

\section{Lithologic and Geophysical Well Logging}

Lithologic logs were recorded for all eight Phase II airrotary-drilled wells, and borehole geophysical logging was conducted in Phase II wells SC-6A, SC-7A, and SC-8A. Well-completion diagrams and lithologic logs for the Hottentot, Hansen, La Bobita, and Capulin (CC-1B and CC-2B) wells are shown in figure 7, and well-completion diagrams, lithologic logs, and geophysical logs for wells SC-6A, $\mathrm{SC}-7 \mathrm{~A}$, and $\mathrm{SC}-8 \mathrm{~A}$ are shown in figure 8 .

\section{Lithologic Logging}

Lithologic logs were constructed from examination of borehole cuttings from the Hottentot, Hansen, La Bobita, and Capulin (CC-1B and CC-2B) wells, and wells SC-6A, SC-7A, and SC-8A (Souder, Miller, and Associates, 2003). Borehole cuttings were collected from all eight wells from land surface to total depth. Cuttings were collected at 5-ft intervals from sampling cyclones and stored in 5-gal (gallon) plastic containers. Representative samples from each 5-ft interval were examined in the field using a hand lens (Souder, Miller, and Associates, 2003). The level of detail in field logging of samples was dictated by the condition of the sample (wet or dry, fine or coarse) and the time available for inspection. Ludington and others (2005) conducted detailed analyses of these samples.

\section{Geophysical Logging}

Natural gamma, induction, and single-detector neutron geophysical logging was conducted in wells SC-6A, SC-7A, and SC-8A (figs. 8A, 8B, and 8C) during February 2003, following well completion and development. Logging and log interpretation was conducted using information regarding geophysical logging applications in ground-water investigations by Keys (1986, 1990), Jorgensen (1991), Paillet and Crowder (1996), and Hearst and others (2000). In completed wells SC-6A, SC-7A, and SC-8A, the conditions in the annulus between the 4-in. PVC casing and the 9-in. diameter bore holes at the time of logging were not representative of the undisturbed aquifer material beyond the borehole, and these disturbed conditions substantially limited interpretations of these logs.

Two primary quality-control measures were used during the collection of geophysical log data. First, an accurate depth scale was ensured by verifying that the depth indicator on the $\log$ recorded a value within about $0.8 \mathrm{in}$. of zero when the probe was returned to the pre-logging measurement reference point. Second, nuclear logging was repeated in selected sections of the wells to verify the repeatability of the initial logging results. 


\section{(A) Hottentot well}

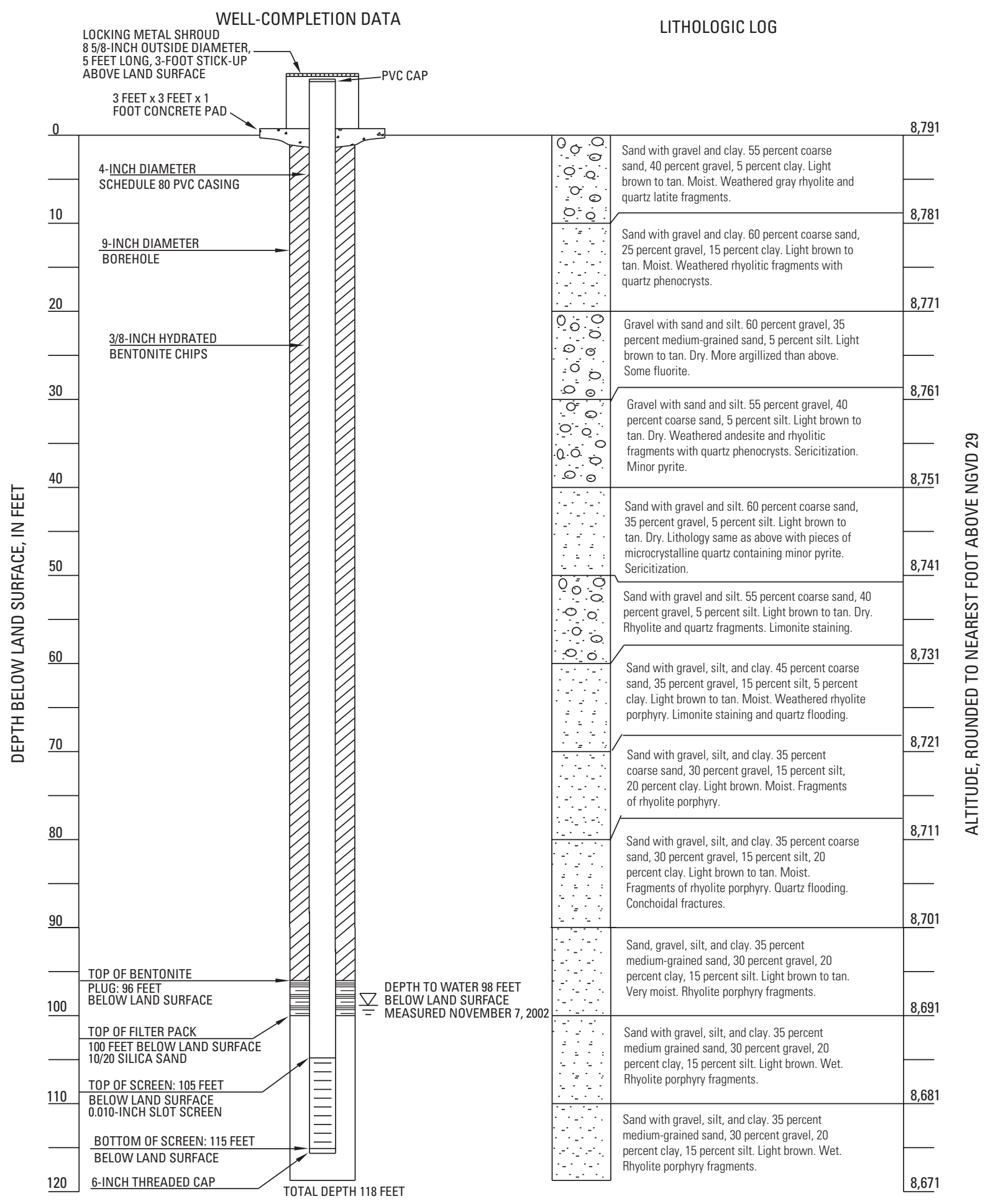

Figure 7A. Well-completion data and lithologic log for Hottentot well (modified from Souder, Miller, and Associates, 2003). 


\section{(B) Hansen well}

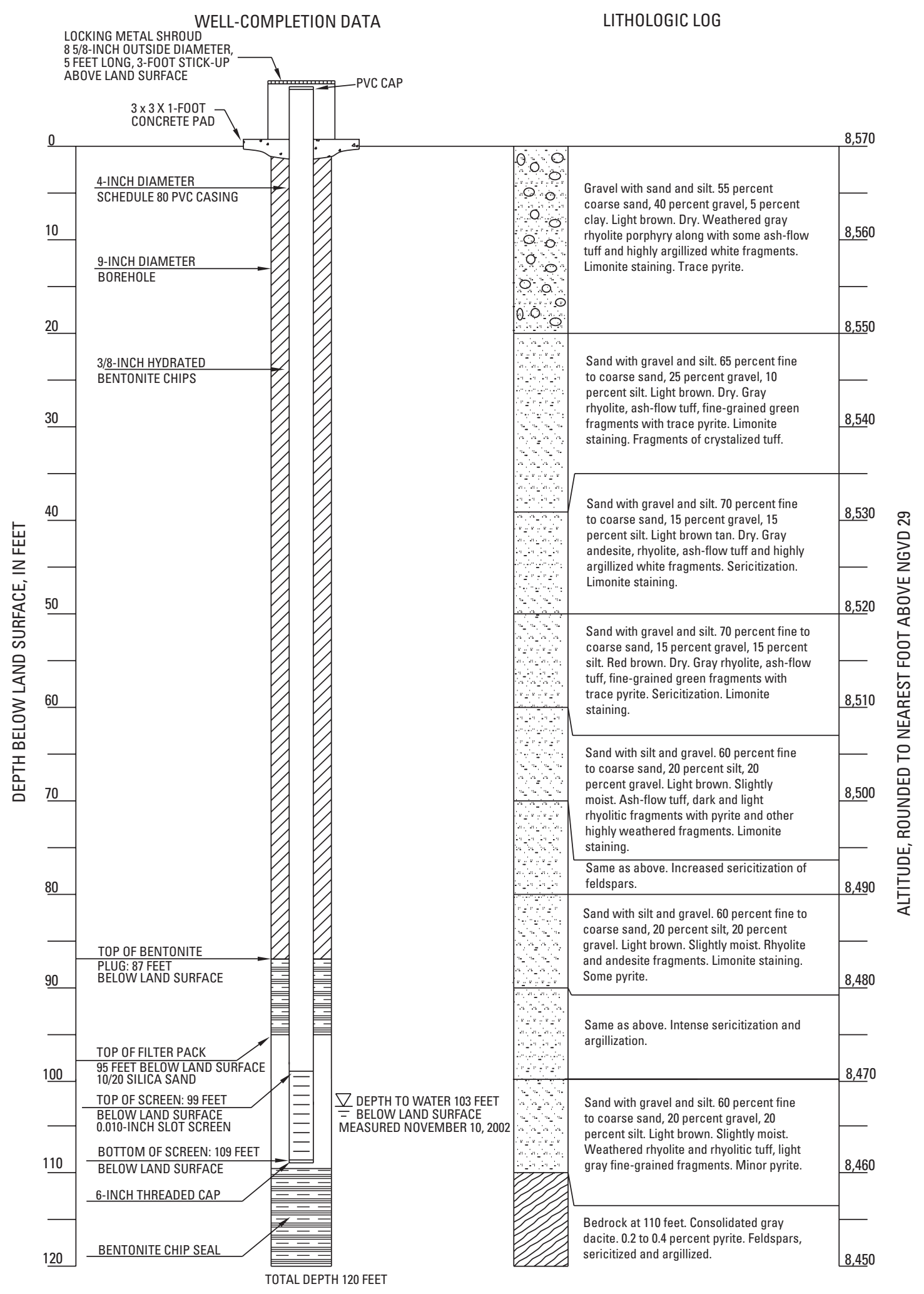

Figure 7B. Well-completion data and lithologic log for Hansen well (modified from Souder, Miller, and Associates, 2003). 


\section{(C) La Bobita well}

LITHOLOGIC LOG
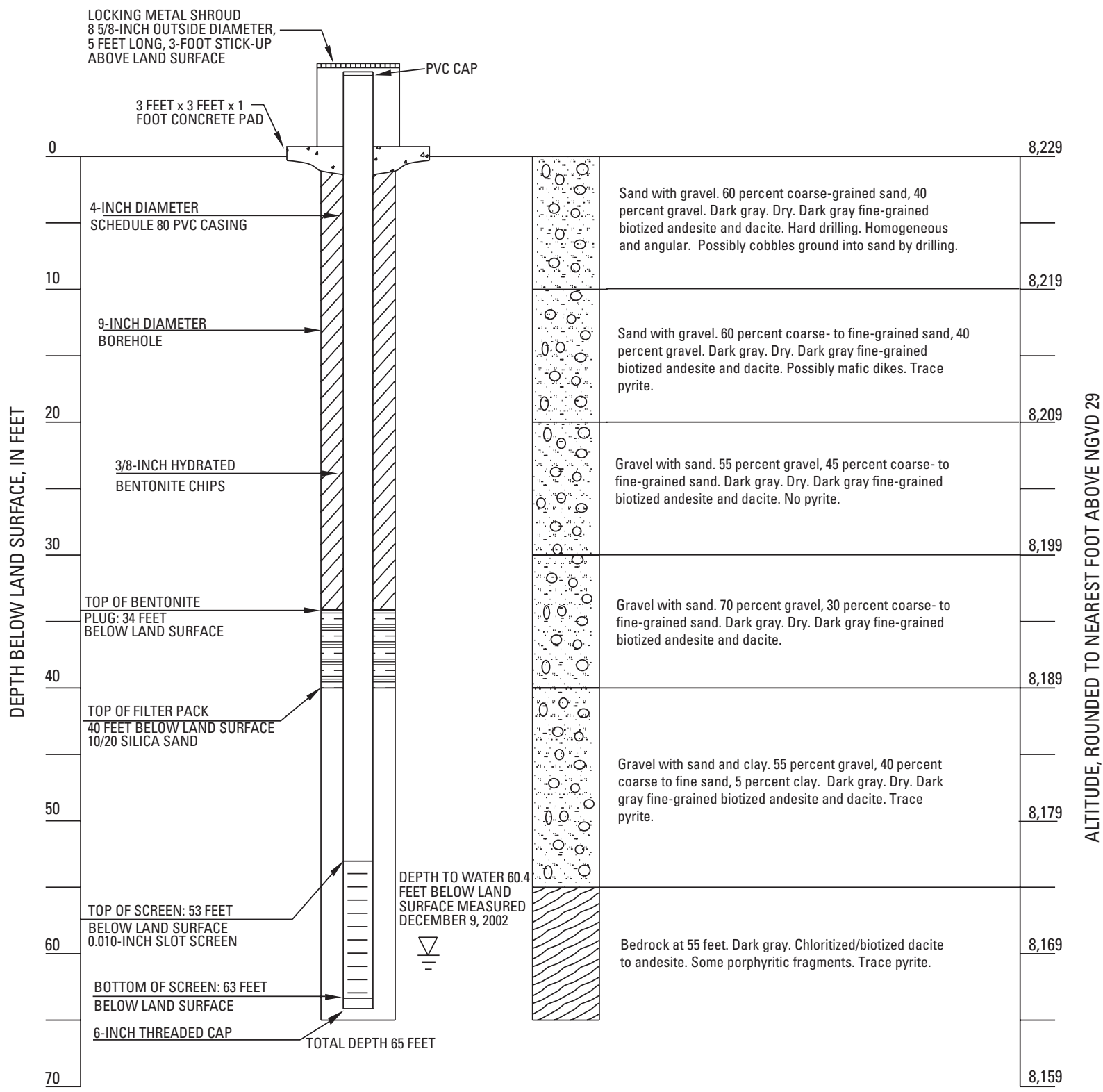

Figure 7C. Well-completion data and lithologic log for La Bobita well (modified from Souder, Miller, and Associates, 2003).

Natural gamma logs are used to estimate the proportion of clay minerals and (or) the proportion of unweathered mineral grains in the aquifer. The log measures the gamma activity produced by naturally occurring isotopes of uranium, potassium, and thorium in the formation beyond the borehole and, therefore, indicates variations in the lithology of aquifer materials. Log units are counts per second (cps). Well-casing and borehole fluid typically attenuate the flux of gamma particles from the undisturbed geologic material beyond the borehole to the detector in the logging tool resulting in reduced gamma counts. To minimize this attenuation, the $\log$ is run with the probe decentralized so that the probe is free to move within and lie against the side of the borehole or well that is not precisely plumb.

The induction log shows the bulk electrical resistivity of the aquifer material and the fluid in the aquifer material's pore spaces. Log units are ohm-meters. Resistivity values can vary depending on the electrical properties of the aquifer material, with the degree of saturation of the aquifer material, and with 


\section{(D) CC-1B well}

WELL-COMPLETION DATA

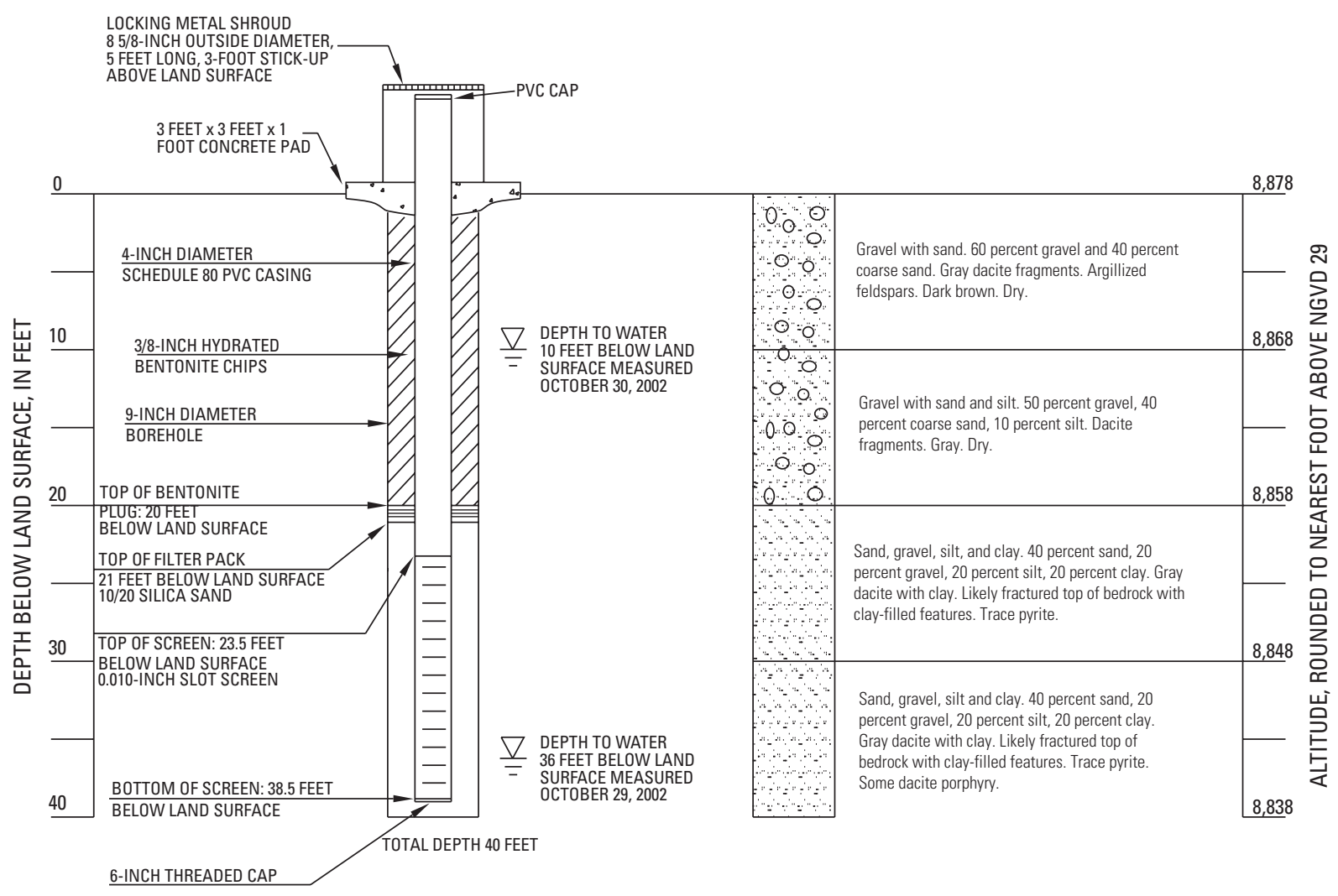

Figure 7D. Well-completion data and lithologic log for CC-1B well (modified from Souder, Miller, and Associates, 2003).

the electrical properties of the water filling pore spaces in the aquifer material.

Single-detector neutron logs provide an estimate of the degree of saturation of aquifer materials and, below the water table, the porosity of these materials. The single-detector neutron log generates a flux of neutrons and measures the rate at which those neutrons are scattered back to the detector. Neutrons generated by the logging tool are absorbed through collision with hydrogen atoms so the count rate is inversely proportional to the total amount of water within a radius of approximately $10 \mathrm{in}$. of the logging tool. To minimize the effects of casing and annulus materials on logging results in completed wells, the single-detector neutron log is run with the probe decentralized and free to move within and lie against the side of a casing that is not precisely plumb. Log units are counts per second. Typically, the response of the single-detector neutron log to fully saturated materials is less than about $2,000 \mathrm{cps}$, the response to partially saturated materials is about 2,000 to $3,500 \mathrm{cps}$, and the response to relatively dry materials is more than about 3,500 cps. Neutron logs in saturated formations respond to the total of effective (drainable) and noneffective (nondrainable and often containing geochemically bound water) porosity.

In completed wells SC-6A, SC-7A, and SC-8A, the conditions in the annulus between the 4-in. PVC casing and the 9-in. diameter boreholes inside the casing and the annulus at the time of logging were not representative of the undisturbed aquifer material beyond the borehole, and these disturbed conditions substantially affected the neutron counts in the saturated zone. Above the water table, however, the results of neutron logging provided some measure of the degree of saturation of the aquifer materials.

In well SC-6A, the gamma count decreased, the resistivity increased, and the neutron count was unusually high (greater than 4,000 cps) between top of the sand pack in the annulus at $122 \mathrm{ft}$ and the top of the saturated zone, about $133 \mathrm{ft}$ at the time logging was conducted (fig. 8A). The unusually high neutron count indicates that the deposits about $11 \mathrm{ft}$ above the water table were dry. The lithologic log, however, indicates that the cuttings retrieved from this interval were wet (fig. 8A). This inconsistency between the lithologic log and the geophysical log interpretation indicates that the change in the 


\section{(E) CC-2B well}

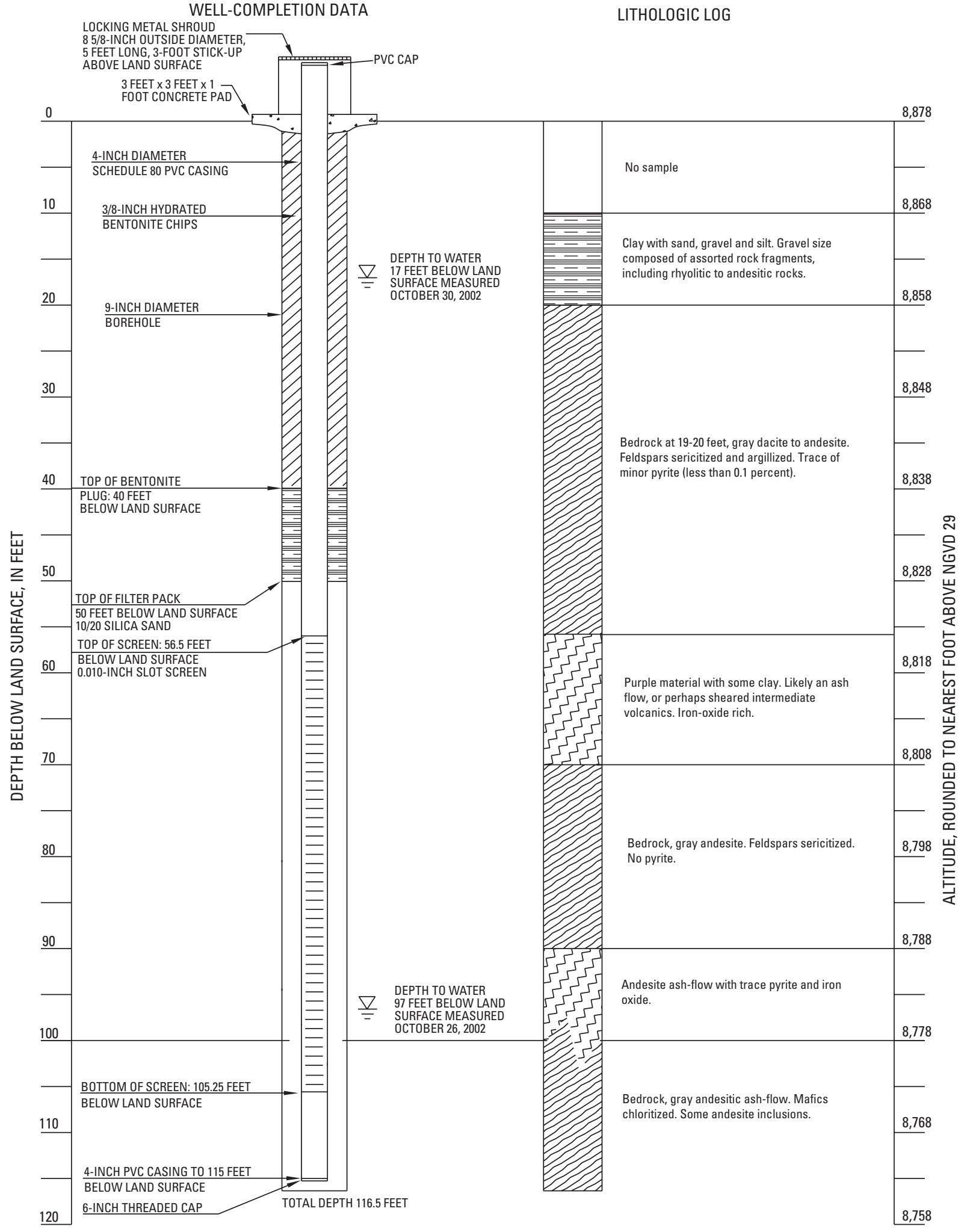

Figure 7E. Well-completion data and lithologic log for CC-2B well (modified from Souder, Miller, and Associates, 2003). 


\section{(A) SC-6A well}

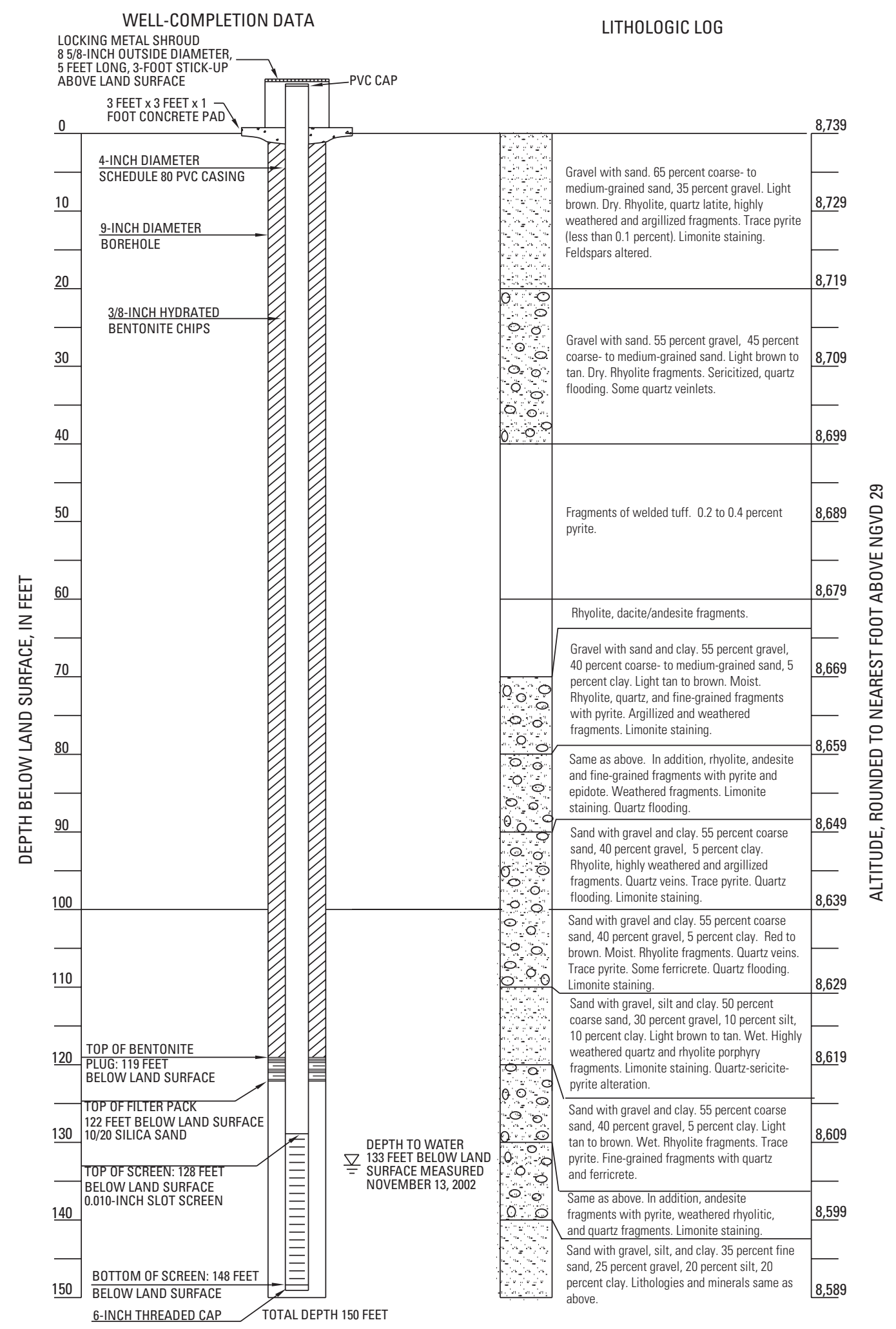

Figure 8A. Well-completion data, lithologic log, and geophysical log for SC-6A well. Well-completion data and lithologic log modified from Souder, Miller, and Associates (2003). 


\section{(A) SC-6A well}

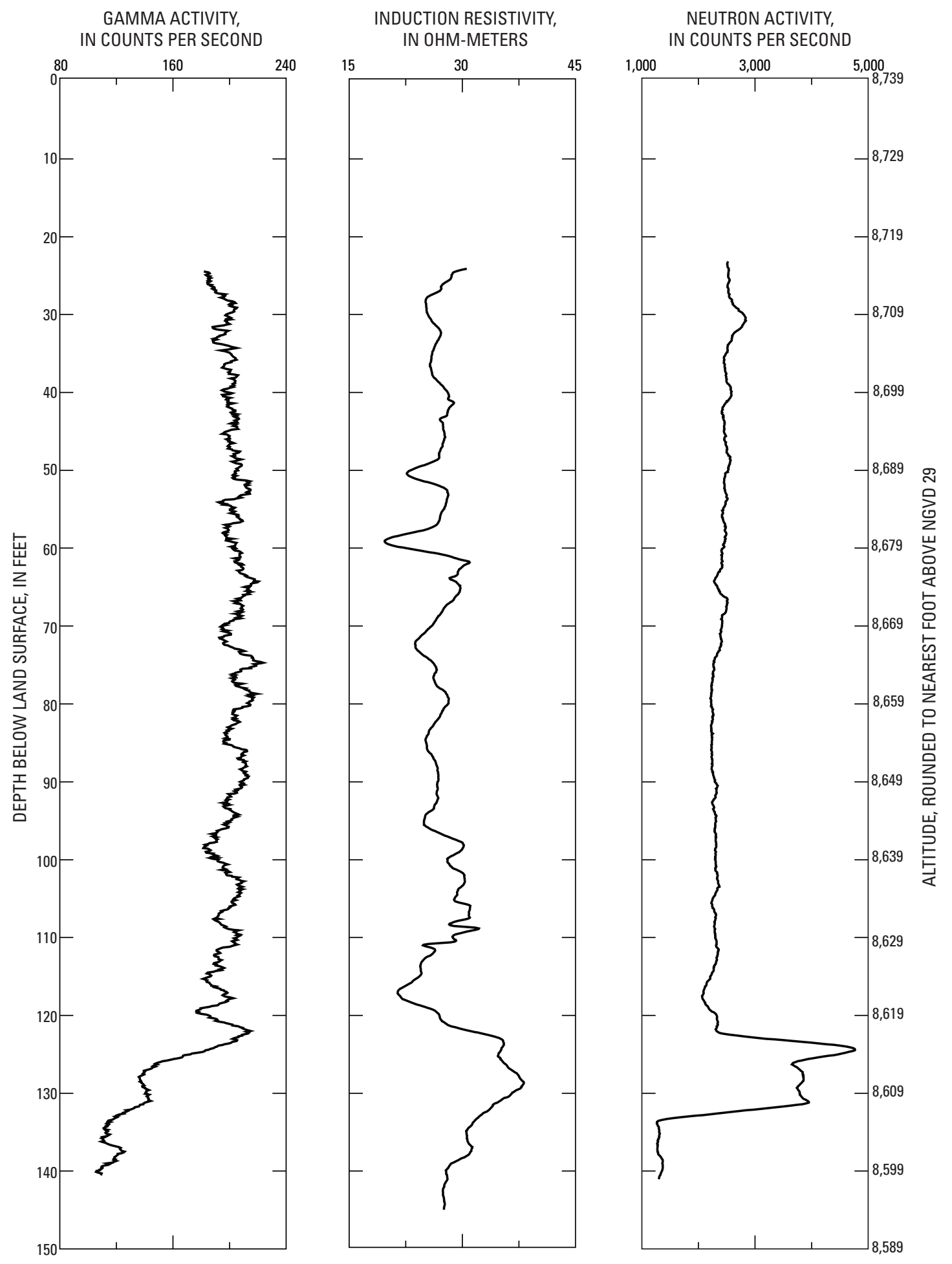

Figure 8A. Well-completion data, lithologic log, and geophysical log for SC-6A well.-Continued Well-completion data and lithologic log modified from Souder, Miller, and Associates (2003). 


\section{(B) SC-7A well}

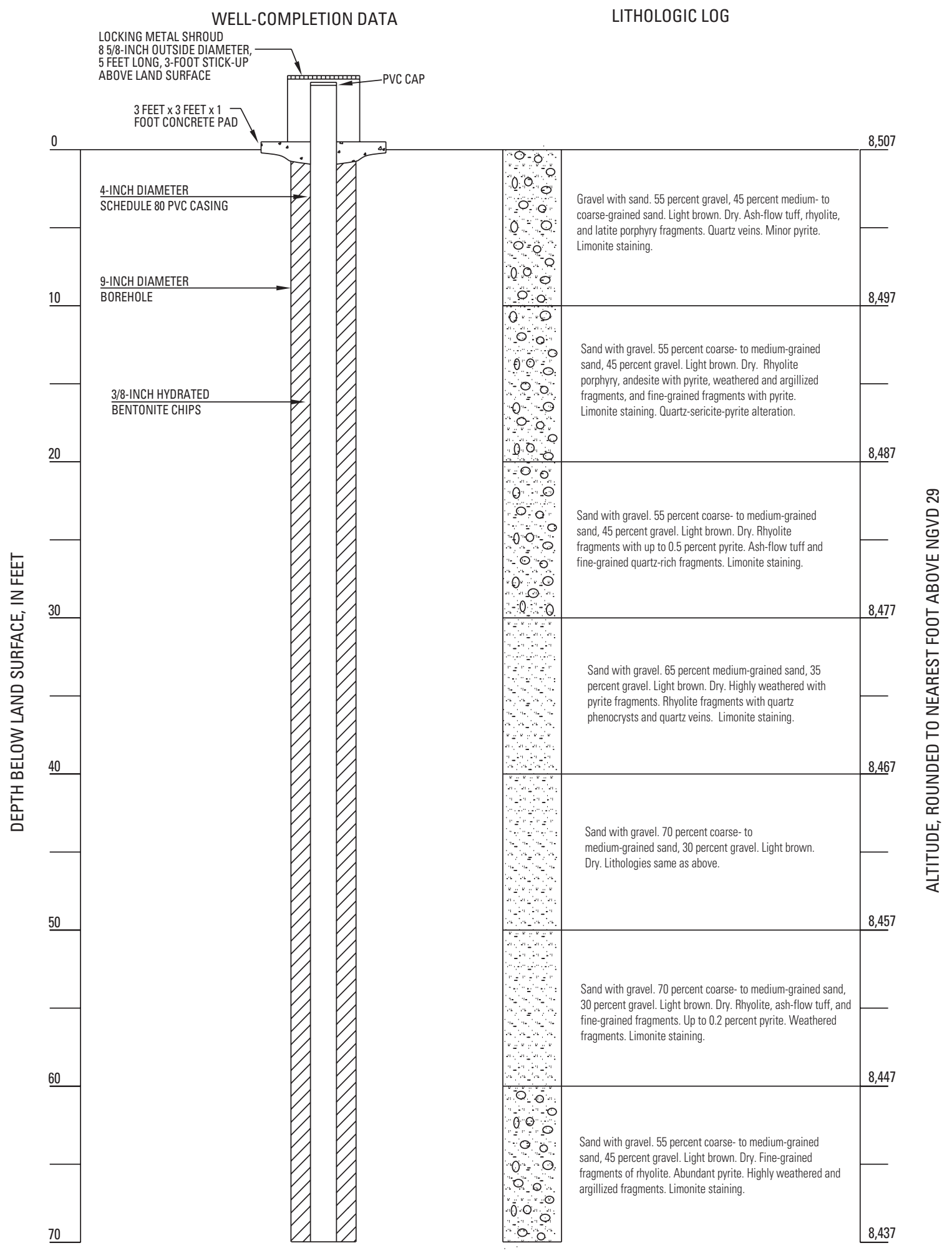

Figure 8B. Well-completion data, lithologic log, and geophysical logs for SC-7A well.-Continued Well-completion data and lithologic log modified from Souder, Miller, and Associates (2003). 


\section{(B) SC-7A well}

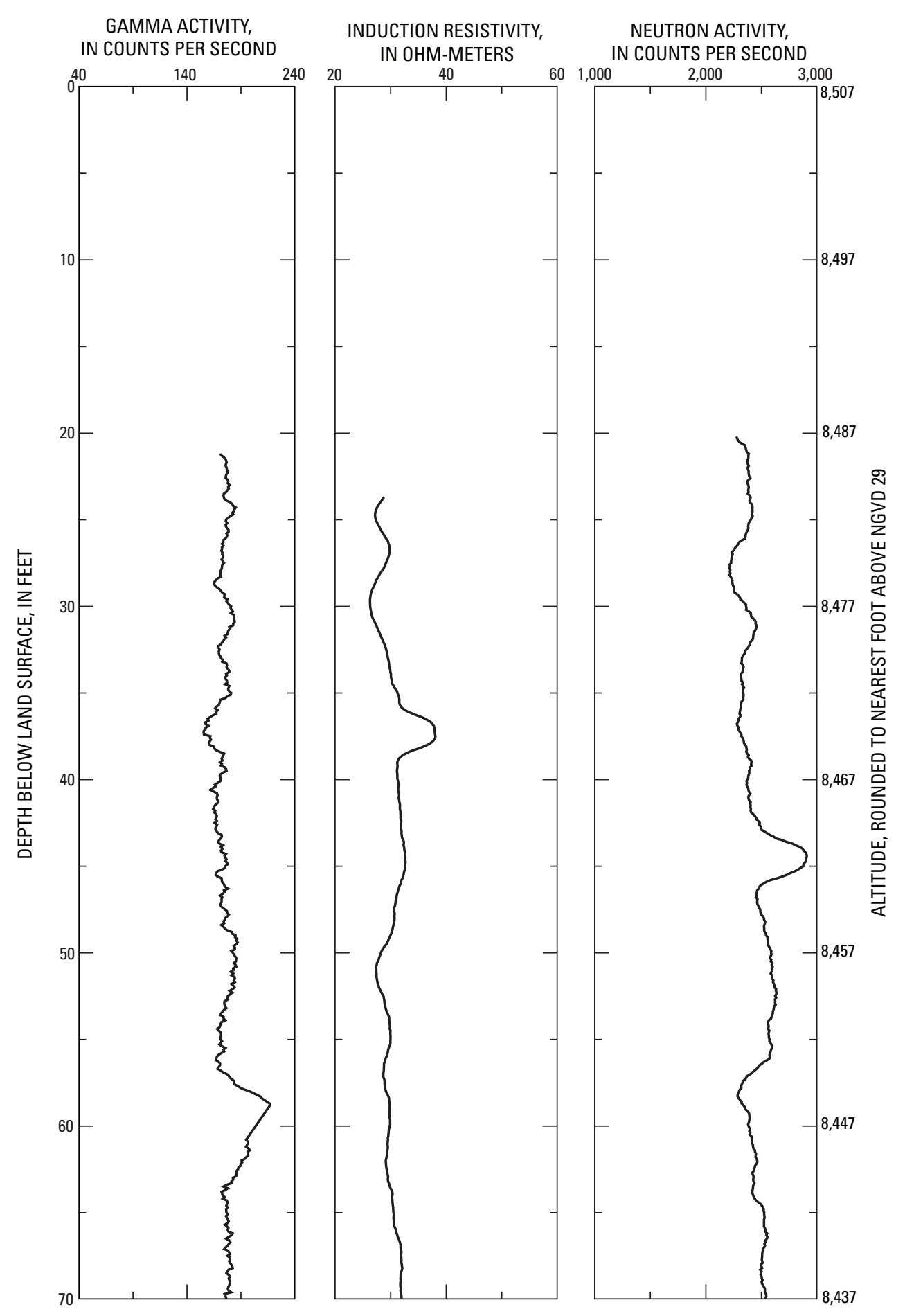

Figure 8B. Well-completion data, lithologic log, and geophysical logs for SC-7A well.-Continued Well-completion data and lithologic log modified from Souder, Miller, and Associates (2003). 


\section{(B) SC-7A well-Continued}

WELL-COMPLETION DATA

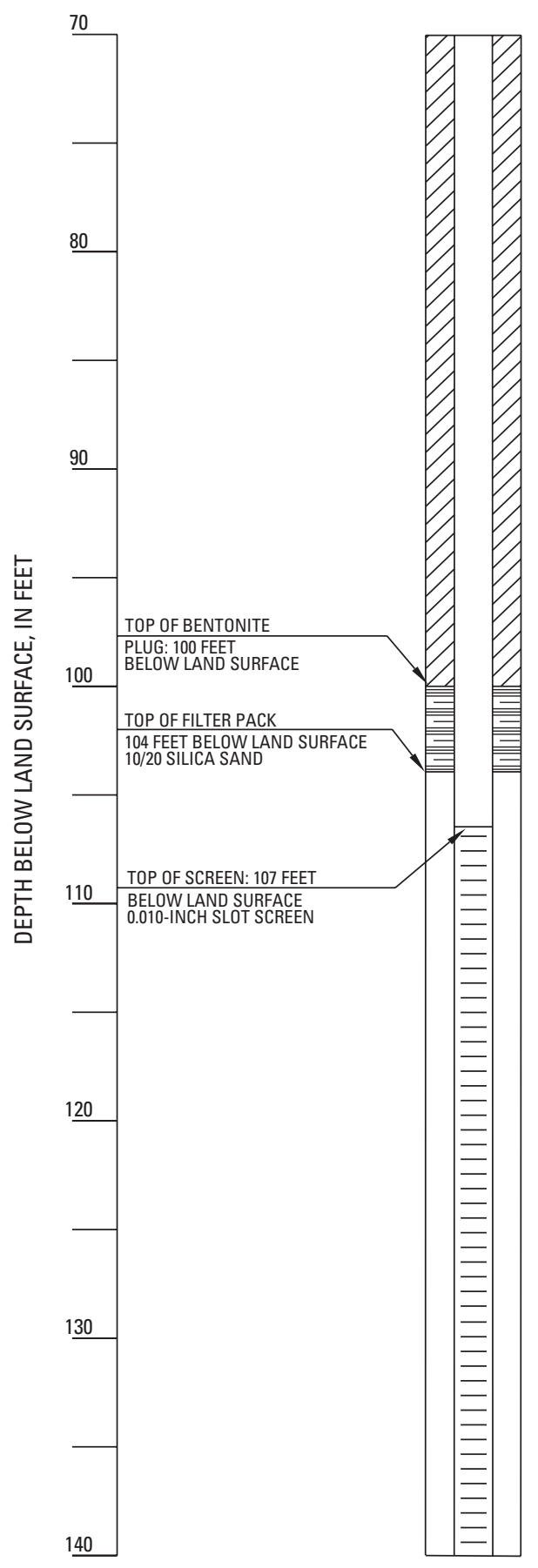

LITHOLOGIC LOG

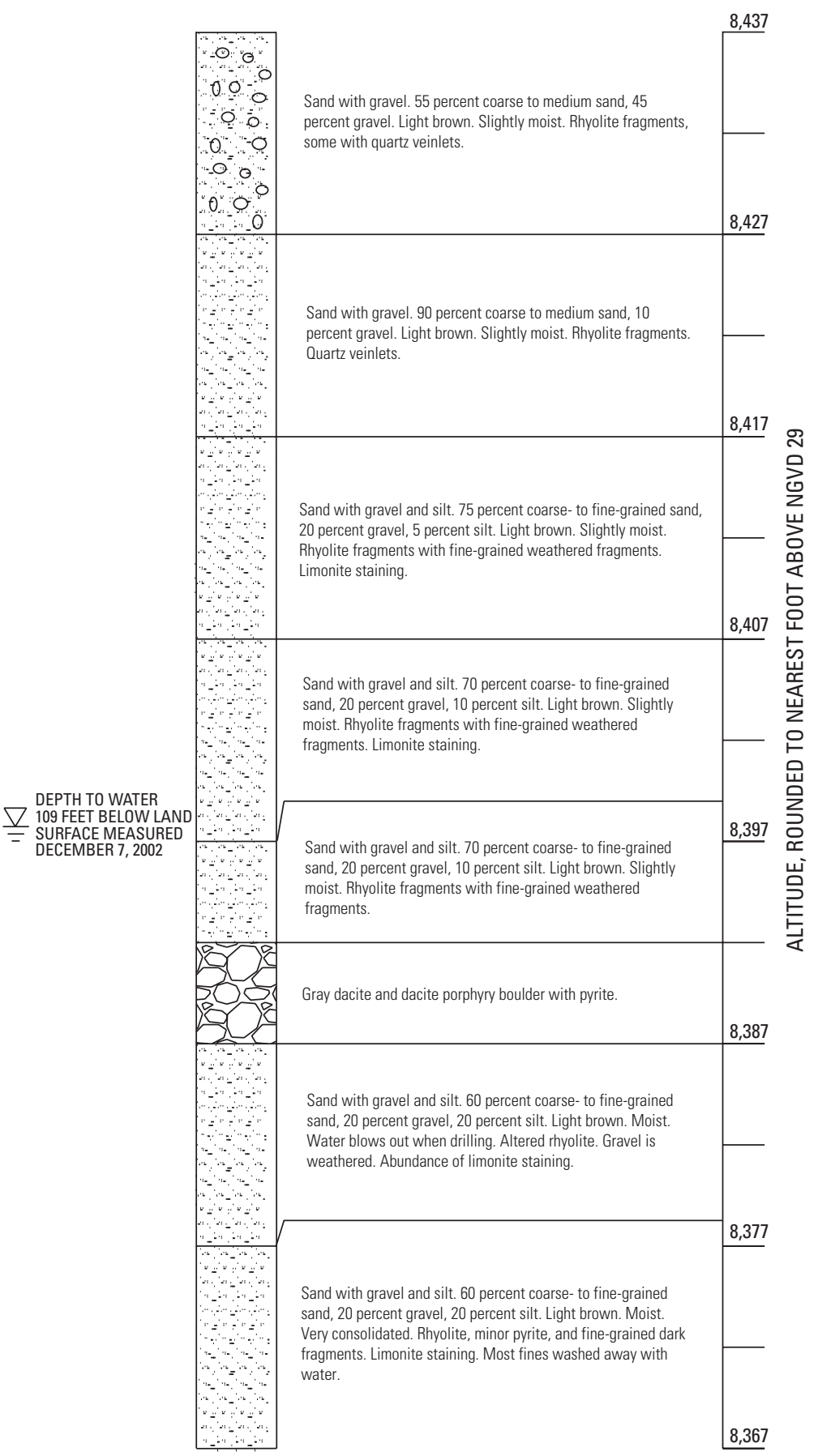

Figure 8B. Well-completion data, lithologic log, and geophysical logs for SC-7A well.-Continued Well-completion data and lithologic log modified from Souder, Miller, and Associates (2003). 


\section{(B) SC-7A well-Continued}

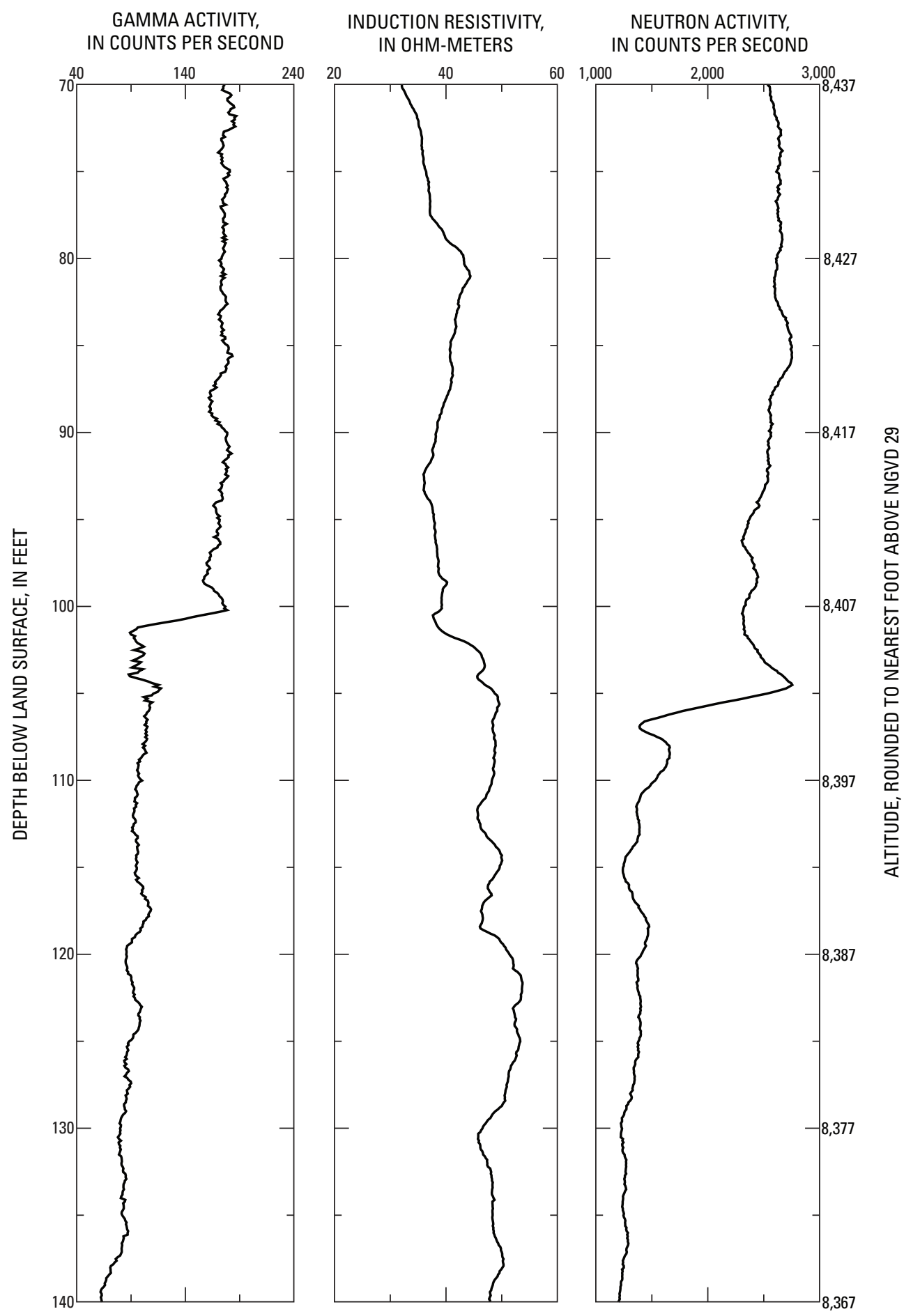

Figure 8B. Well-completion data, lithologic log, and geophysical logs for SC-7A well.-Continued Well-completion data and lithologic log modified from Souder, Miller, and Associates (2003). 


\section{(B) SC-7A well-Continued}

WELL-COMPLETION DATA

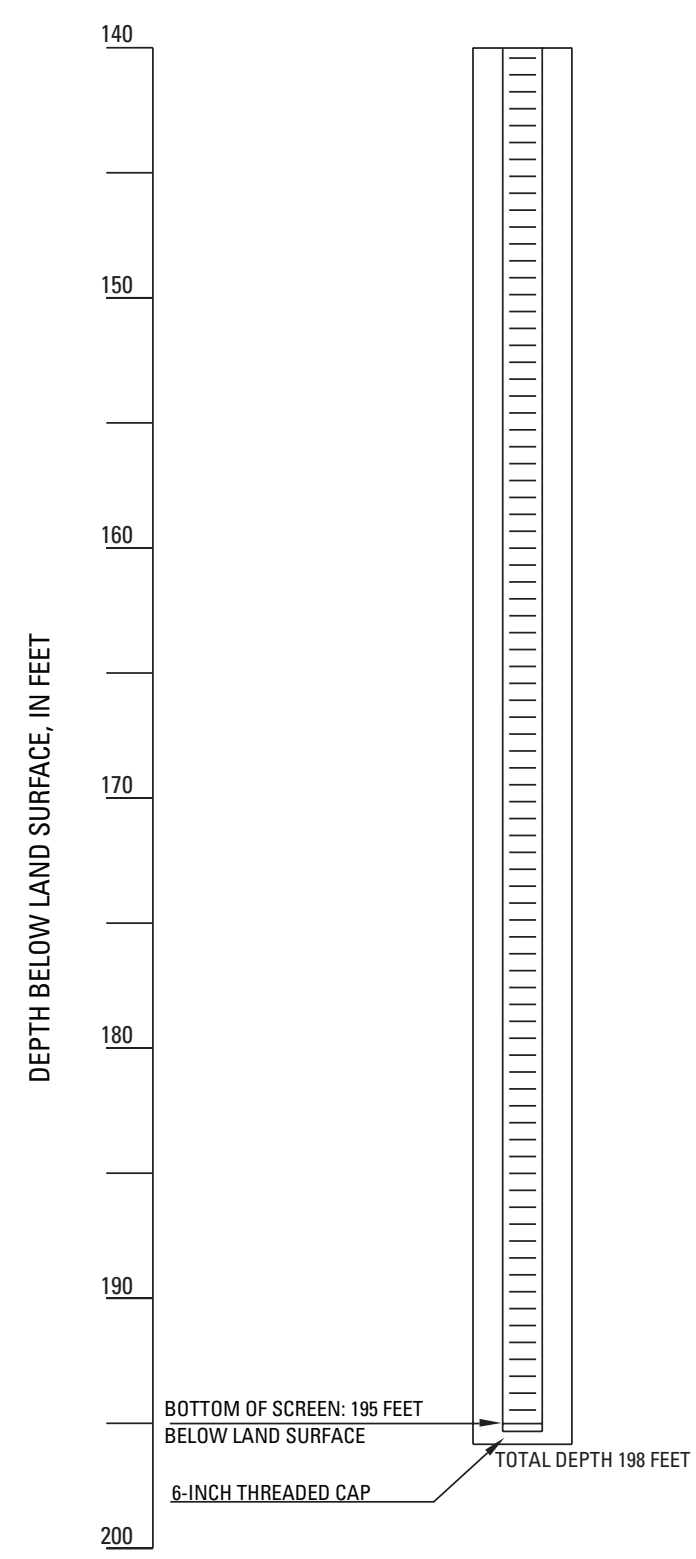

LITHOLOGIC LOG

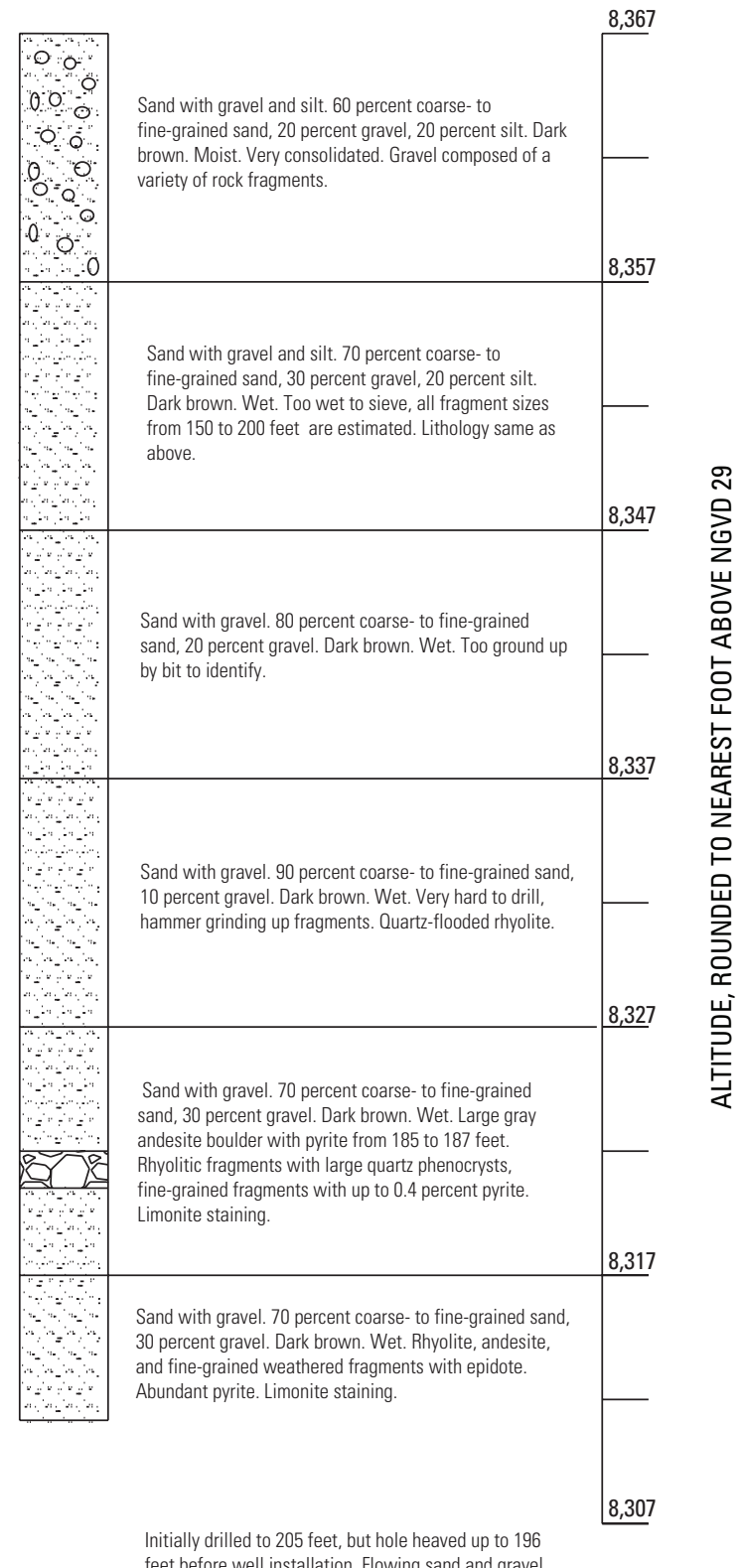

Figure 8B. Well-completion data, lithologic log, and geophysical logs for SC-7A well.—Continued Well-completion data and lithologic log modified from Souder, Miller, and Associates (2003). 


\section{(B) SC-7A well-Continued}

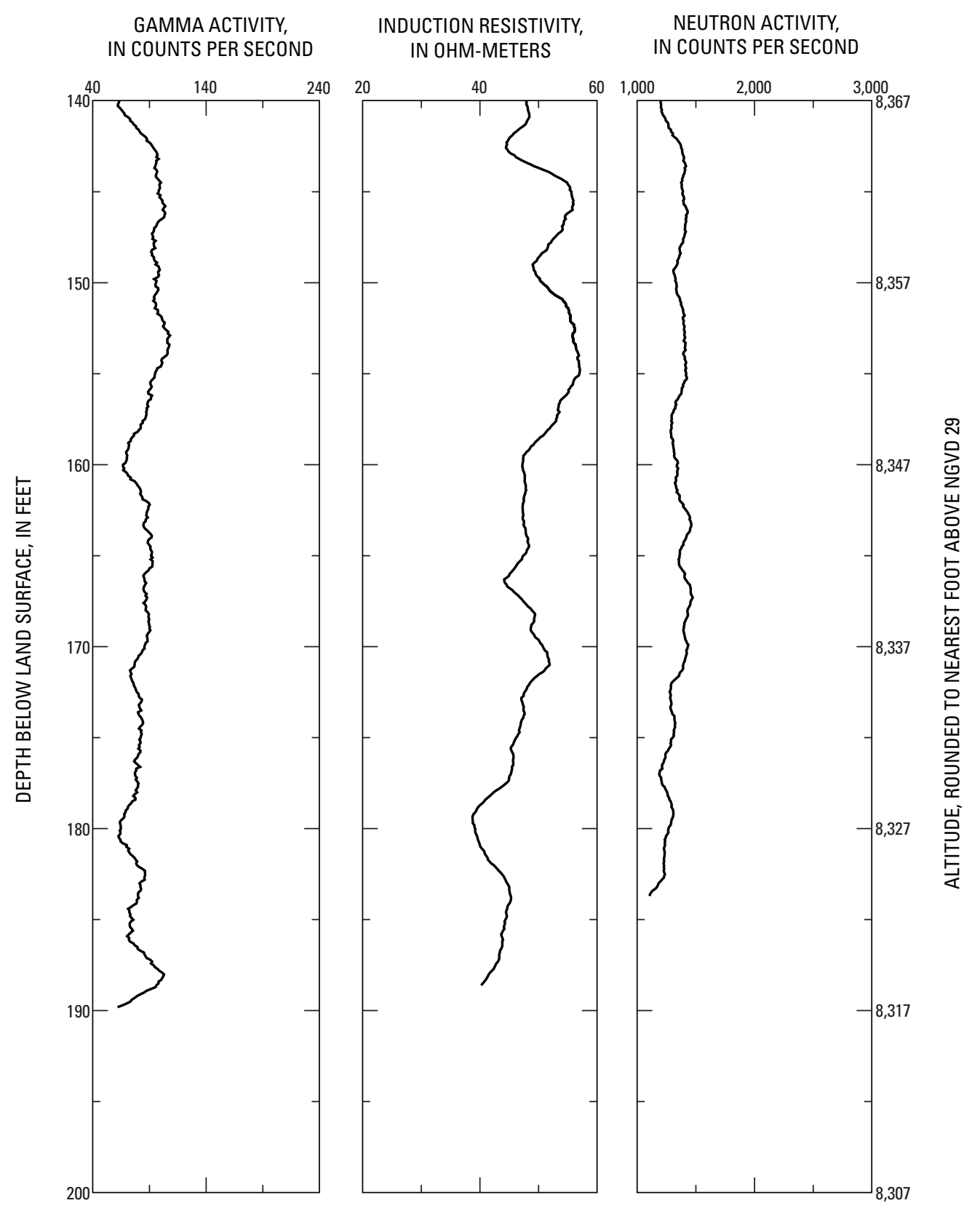

Figure 8B. Well-completion data, lithologic log, and geophysical logs for SC-7A well.-Continued Well-completion data and lithologic log modified from Souder, Miller, and Associates (2003). 


\section{(C) SC-8A well}

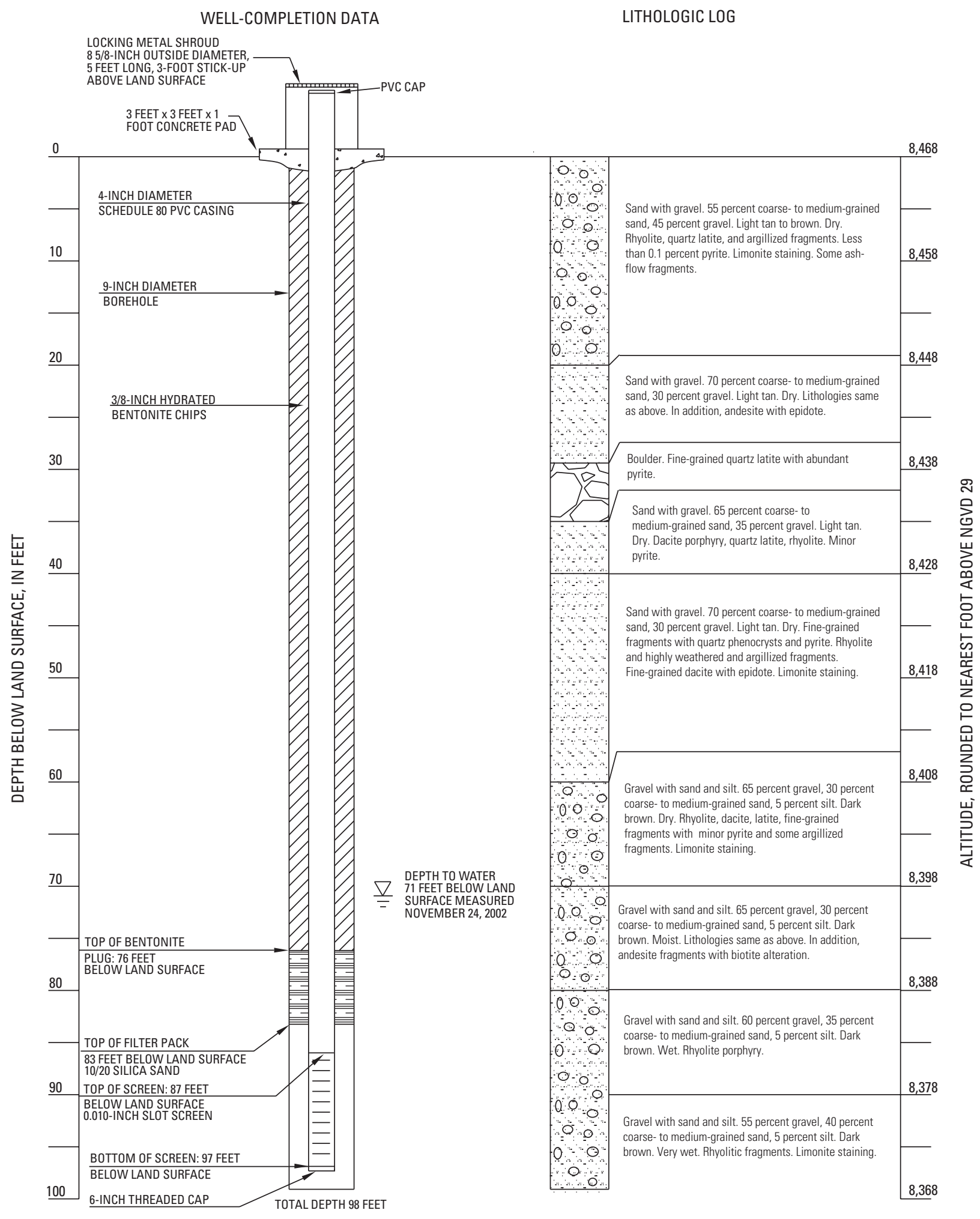

Figure 8C. Well-completion data, lithologic log, and geophysical logs for SC-8A well.

Well-completion data and lithologic log modified from Souder, Miller, and Associates (2003). 


\section{(C) SC-8A well}
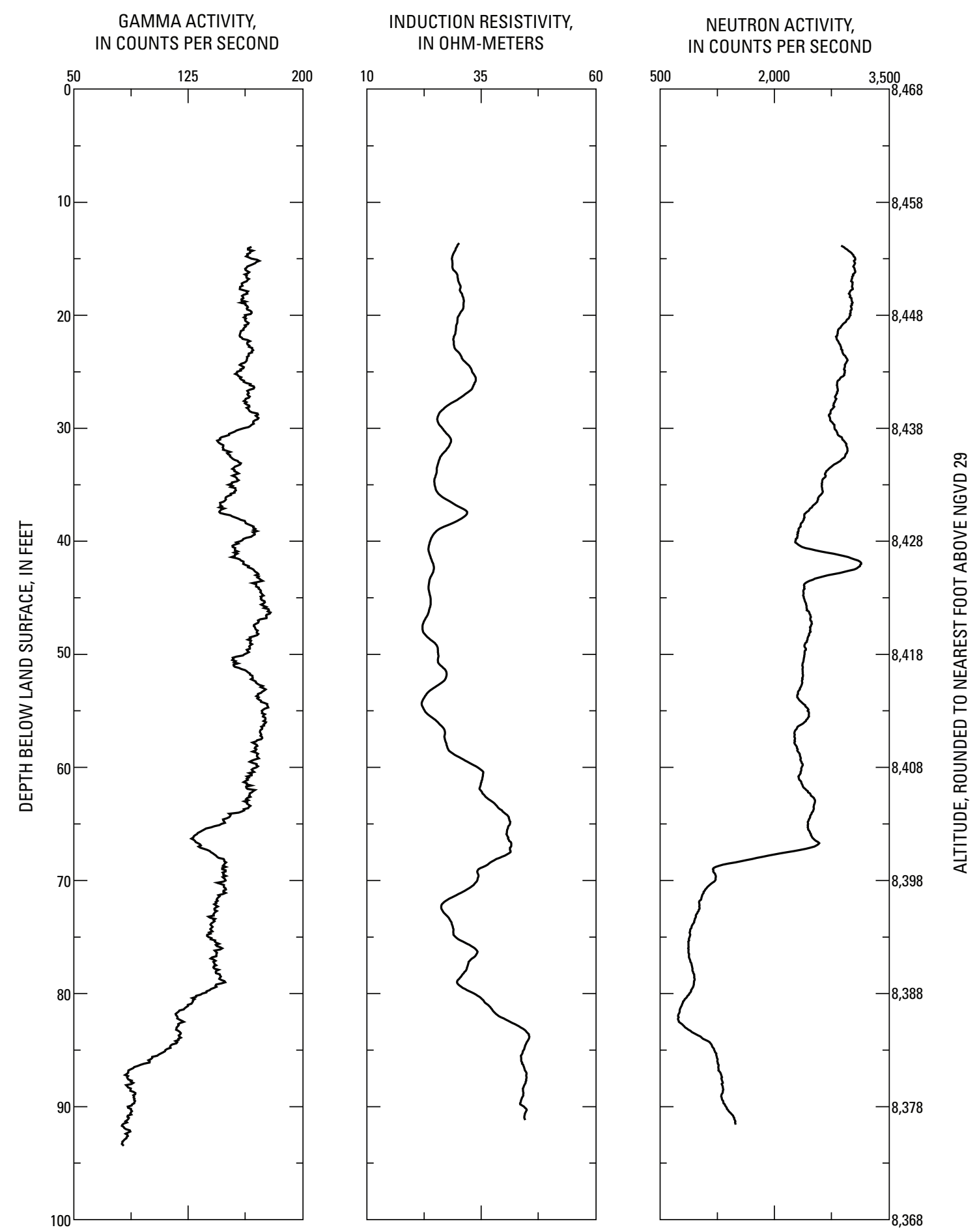

Figure 8C. Well-completion data, lithologic log, and geophysical logs for SC-8A well.—Continued Well-completion data and lithologic log modified from Souder, Miller, and Associates (2003). 
geophysical log may be related to geologic conditions rather than a lack of moisture.

In well SC-7A, resistivity measurements ranged from 30 to $40 \mathrm{ohm}$-meters, and neutron counts ranged from 2,000 to $3,000 \mathrm{cps}$ from land surface to the water table, about $109 \mathrm{ft}$ below land surface at the time logging was conducted. These values suggest that the deposits above the water table were dry to partially saturated (fig. $8 B$ ).

In well SC-8A, typical resistivity measurements of about $30 \mathrm{ohm}-$ meters and typical neutron counts of about 2,000 to 3,000 cps above the water table, about $71 \mathrm{ft}$ below land surface at the time logging was conducted, indicate that these deposits were partially saturated (fig. $8 \mathrm{C}$ ) though the water content may not have been high enough to note on the lithologic log. A slight increase in resistivity and decrease in gamma activity from 60 to $69 \mathrm{ft}$ corresponds to the presence of gravel-sized deposits described in the driller's log (fig. 8C). The increasing neutron count with depth in the screened interval (87.5 to $97 \mathrm{ft}$ ) indicates that porosity decreased with depth in this interval.

\section{Hydraulic Testing to Determine Aquifer Characteristics}

A flow-meter survey and several aquifer tests were conducted during 2003 to estimate the hydraulic properties of debris-flow deposits, bedrock, and Red River alluvial deposits in and near Straight Creek. A flow-meter survey was conducted in well $\mathrm{SC}-7 \mathrm{~A}$, slug tests were conducted in wells SC-1A, SC-1B, SC-2B, SC-3A, SC-3B, SC-4A, SC-5A, SC-5B, SC-6A, SC-7A, and SC-8A, and a pumping test was conducted at the mouth of the Straight Creek drainage in well AWWT-1. Wells AWWT-2, SC-5A, SC-5B, SC-7A and $\mathrm{SC}-8 \mathrm{~A}$ were used to monitor ground-water levels during the pumping test.

\section{Flow-Meter Survey in Well SC-7A}

A flow-meter survey was conducted in well SC-7A on October 27, 2003, to determine the vertical distribution of flow to the well through the interval open to the aquifer. The SC-7A well screen extends from about $107 \mathrm{ft}$ to about $195 \mathrm{ft}$ below land surface and, at the time of the test, was entirely below the water level in the well.

Prior to the survey, a flow meter was lowered to about $150 \mathrm{ft}$, and a pump was lowered to about $10 \mathrm{ft}$ below the static water level (about $114 \mathrm{ft}$ below land surface). The well was pumped at a rate of $3.64 \mathrm{gal} / \mathrm{min}$ (gallons per minute); this pumping rate was constant throughout the test. Drawdown in the well reached steady state at $0.07 \mathrm{ft}$ below the static water level. The flow meter was raised and lowered incrementally in the well to measure the vertical distribution of flow produced by the pumping. The flow rates indicated the relative contribution of water to the well from each increment (fig. 9).

Results of the flow-meter survey indicated that nearly all water entered well SC-7A from two zones-one approximately 10-ft-thick zone near the top of the screened interval (107-117 ft below land surface) and one approximately 15-ftthick zone near the bottom of the screened interval (177-192 ft below land surface). About 77 percent of the water entered the well through the upper zone, and about 23 percent of the water entered the well through the lower zone (fig. 9); less than 1 percent of the water entered the well between these two zones. The lithologic log of well SC-7A (fig. 8B) indicates that boulders were present within both of these zones.

\section{Slug Tests Conducted in Selected Phase I and II Drilled Wells}

Slug tests were performed in wells $\mathrm{SC}-1 \mathrm{~A}, \mathrm{SC}-1 \mathrm{~B}$, SC-2B, SC-3A, SC-3B, SC-4A, SC-5A, SC-5B, SC-6A, $\mathrm{SC}-7 \mathrm{~A}$, and SC-8A during June 3-5, 2003. Water-level data were recorded during each slug test using a submersible pressure transducer connected to a data logger. The data logger was programmed to collect data in the early stages of slug tests at a rate of once every 0.125 second, and in the later stages of slug tests at a rate of once every 5 seconds. Water in the wells was displaced (raised or lowered) by means of a slug, a sealed 2-in. outside diameter, 5.5-ft long, schedule 80 PVC pipe filled with sand. Slug tests were performed using both slug-in and slug-out techniques.

The slug-in test procedure was as follows. The static water level in the well was measured using an electric tape shortly before introduction of the slug. The slug was lowered to just above the static water level in the well. Then, data logger recording was initiated shortly before the slug was rapidly and completely submerged below the static water level in the well.

The slug-out procedure, usually done following a slug-in test, was as follows. The water level in the well was measured using an electric tape to determine if the water level had returned to the static level, and then data logger recording was initiated shortly before the slug was rapidly and completely removed from the well.

All slug-test data except that from wells SC-7A and SC-8A were analyzed using the method of Bouwer and Rice (1976) as implemented in the AQTESOLV computer program (Duffield, 2000). Water levels in wells SC-7A and SC-8A exhibited oscillatory behavior (oscillations from above to below the static water level) during slug tests and, therefore, were analyzed using the method of van der Kamp (1976) as implemented in the van der Kamp spreadsheet developed by Halford and Kuniansky (2002). The van der Kamp (1976) method assumes that the well screen fully penetrates the saturated aquifer-a condition met for well SC-7A but not for well SC-8A. Thus, an estimated range of likely hydraulicconductivity values is reported for well SC-8A. Analytical 

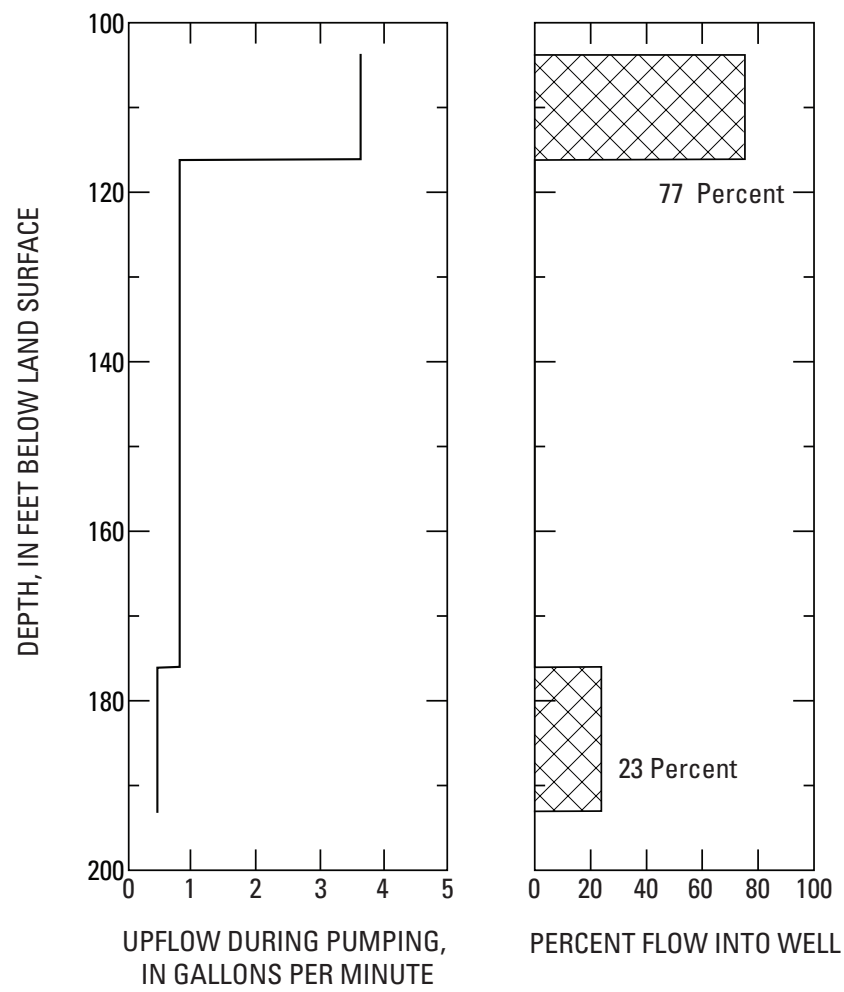

Figure 9. Vertical distribution of borehole flow measured during pumping and corresponding percentage of flow into well SC-7A.

solutions within both the AQTESOLV program and the van der Kamp spreadsheet were obtained by manually fitting straight-line segments to the data.

Because of the limited radius of investigation of a slug test (Halford and Kuniansky, 2002), the aquifer interval contributing water during a slug test was assumed to be the aquifer interval adjacent to the well screen. During installation, the SC-1A, SC-3A, SC-4A, SC-5A, and SC-6A well screens were placed primarily in Straight Creek debris-flow deposits, but some of these screens also penetrated bedrock. For consistency, hydraulic-conductivity values were estimated for that part of the each well's screen that was in debris-flow deposits. Hydraulic-conductivity values were estimated for a vertical-to-horizontal hydraulic-conductivity ratio of 0.01 .

On the basis of the above variables, hydraulic-conductivity values were estimated for the wells (table 2). For the wells with screens in debris-flow deposits (wells SC-1A, SC-3A, SC-4A, and SC-6A), the mean and median estimated hydraulic conductivities were 15.25 and $15.35 \mathrm{ft} / \mathrm{d}$ (feet per day), respectively. For the wells with screens in bedrock (wells SC-1B, SC-2B, SC-3B, and SC-5B), the mean and median estimated hydraulic conductivities were 0.12 and $0.08 \mathrm{ft} / \mathrm{d}$, respectively (table 2). For the wells with screens in mixed debris-flow deposits and Red River alluvium (wells SC-5A, SC-7A, and SC-8A), the mean and median estimated hydraulic conductivities were 73-207 (estimated range) and $80 \mathrm{ft} / \mathrm{d}$. Although there is some overlap of the estimated hydraulicconductivity values between the groups of wells, the mean and median values indicate that, in general, bedrock has the smallest hydraulic conductivity, debris-flow deposits have the next highest hydraulic conductivity, and mixed debris-flow deposits and Red River alluvium have the largest hydraulic conductivity.

Variations in hydraulic conductivity over short distances, such as between wells SC-3A, SC-4A, and SC-6A, are an indication of the heterogeneity of the debris-flow deposits. The variations in estimated hydraulic conductivity are consistent with field observations along Straight Creek such as the debris-flow deposits consist of massive beds with discontinuous layers of poorly sorted clay- to boulder-size material that may be interlayered with thin beds, generally less than a foot thick, of well-sorted sand and gravel. Thus, wells separated by short distances can exhibit very different hydraulic properties.

It is interesting to note that for the wells with screens in mixed debris-flow deposits and Red River alluvium, the largest hydraulic conductivity was estimated for the well (SC-8A)

Table 2. Estimated hydraulic-conductivity values for slug tests conducted June 3-5, 2003, for selected wells in Red River Valley, northcentral New Mexico.

[e, estimated value-actual value probably is within the indicated range. The actual value is uncertain because the well screen did not fully penetrate the aquifer as assumed by the van der Kamp (1976) method]

\begin{tabular}{|c|c|c|c|c|c|}
\hline \multicolumn{6}{|c|}{ Hydraulic conductivity, in feet per day } \\
\hline \multicolumn{6}{|c|}{ Wells completed in debris-flow deposits } \\
\hline $\mathrm{SC}-1 \mathrm{~A}$ & $\mathrm{SC}-3 \mathrm{~A}$ & $\mathrm{SC}-4 \mathrm{~A}$ & SC-6A & Mean & Median \\
\hline 0.7 & 0.3 & 30 & 30 & 15.25 & 15.35 \\
\hline \multicolumn{6}{|c|}{ Wells completed in bedrock } \\
\hline SC-1B & $\mathrm{SC}-2 \mathrm{~B}$ & $\mathrm{SC}-3 \mathrm{~B}$ & $\mathrm{SC}-5 \mathrm{~B}$ & Mean & Median \\
\hline 0.06 & 0.1 & 0.005 & 0.3 & 0.12 & 0.08 \\
\hline \multicolumn{6}{|c|}{ Wells completed in mixed Red River alluvium and debris-flow deposits } \\
\hline $\mathrm{SC}-5 \mathrm{~A}$ & $\mathrm{SC}-7 \mathrm{~A}$ & $\mathrm{SC}-8 \mathrm{~A}$ & & Mean & Median \\
\hline 40 & 80 & e $100-500$ & & e 73-207 & 80 \\
\hline
\end{tabular}


closest to the axis of the Red River Valley. This may be an indication that debris-flow deposits near the central part of the Red River Valley (or farther away from the source of debrisflow material) are more likely to be reworked and sorted into hydraulically transmissive alluvial deposits than are the debrisflow deposits near margins of the valley.

\section{Pumping Test Conducted at Mouth of Straight Creek Drainage}

A pumping test was conducted to estimate the hydraulic properties of mixed debris-flow deposits and Red River alluvium at the mouth of the Straight Creek drainage. The aquifer test was conducted December 3-4, 2003, using well AWWT-1 as the pumped well, and wells AWWT-2, SC-5A, SC-5B, SC-7A, and SC-8A as observation wells. Well AWWT-2 is completed in bedrock that is horizontally adjacent to mixed debris flow and Red River alluvium, but water levels in the well did not show a measurable response to pumping (discussed later in this report); therefore, it was not used in the aquifer-test analysis. Well $\mathrm{SC}-5 \mathrm{~B}$ is completed in bedrock; wells AWWT-1, SC-5A, SC-7A, and SC-8A are completed in mixed debris-flow deposits and Red River alluvium.

The pumping test was conducted as follows. Pressure transducers were installed in wells AWWT-1, AWWT-2, SC-7A, and SC-8A on November 22, 2003, to allow for measurement of pre-pumping water-level trends. Wells SC-5A and $\mathrm{SC}-5 \mathrm{~B}$ had been equipped previously with pressure transducers. During the week of December 1, 2003, a submersible pump was installed in well AWWT-1. Pumping for the aquifer test began at 2:05 p.m. on December 3, 2003. The pumping rate was monitored using a totalizing flow meter located near the well head. The measured pumping rate ranged from 104.5 to $108.6 \mathrm{gal} / \mathrm{min}$ with a time-weighted average of $106 \mathrm{gal} / \mathrm{min}$. The water from well AWWT-1 was pumped into a nearby unused sewage lagoon. Water levels measured by pressure transducers in the pumped well and in the observation wells were recorded by a data logger eight times per second for the first minute of the test, once a second for the next 9 minutes, and then the recording interval was increased over time to a maximum of 15 minutes. Barometric pressure also was recorded prior to and during the pumping test for use in correcting the water-level data for changes in barometric pressure.

Pre-pumping monitoring indicated that water levels were rising in all of the pumping-test wells from late November to about December 2, 2003, (fig. 10A). Water levels stopped rising on December 3, just prior to initiation of the pumping test, and began falling after initiation of pumping. Pre-pumping monitoring indicated that water-level variations in well AWWT-2 closely followed variations in barometric pressure and that the water-level variations caused by barometricpressure changes masked any observable water-level change caused by pumping well AWWT-1 (fig. 10B). Other wells did not show a discernable relation between water-level and barometric-pressure changes.

The change in water-level trends just prior to initiation of the pumping test makes the corrections in drawdown measured during the test difficult for all but the pumping well. The drawdown in the pumping well was relatively large compared with the water-level-trend changes. But, drawdowns measured in the observation wells were relatively small compared to the changing water-level trends. Pre- and post-test water levels from wells AWWT-1, SC-5A, SC-5B, and SC-7A were used to correct for water-level trends not attributed to the test pumping. However, because of the changing trends in background water levels, corrected drawdown from the early part of the test was considered more reliable than corrected drawdown from the later part of the test. Therefore, the early part of the test was used in the test analysis.

Analysis of the pumping test water-level data from wells SC-5A and SC-7A using standard curve-matching techniques and type curves for non-steady radial flow (Theis, 1935) indicated that estimated transmissivity was 12,000 to $34,000 \mathrm{ft}^{2} / \mathrm{d}$ (feet squared per day), and estimated hydraulic conductivity was 230 to $340 \mathrm{ft} / \mathrm{d}$ (table 3). Pumping-test data from wells AWWT-2 and SC-8A were not analyzed because the water levels in these wells did not visibly respond to pumping. Data from well AWWT-1 was not analyzed because most of the drawdown in the well probably resulted from hydraulic head losses that occurred as ground-water flowed in through the well screen. The water-level response to pumping in well SC-5B was judged to be a pressure response and an indication of hydraulic connection between bedrock and the overlying mixed debris-flow deposits and Red River alluvium.

\section{Water-Level Measurements}

Periodic manual water-level measurements were made at each observation well using a steel or electric tape. Measurements were recorded to the nearest $0.01 \mathrm{ft}$ and were repeated until the precision was within $0.02 \mathrm{ft}$.

Hydrographs of manually measured water-level altitudes in Phase II wells, except well SC-9A, are shown in figures 11-13. Streamflow and stage in the Red River also are shown in figure 11 . The hydrographs of water levels in the Capulin Canyon wells (fig. 13) include measurements made by the USGS and the measurements made by URS, Denver, Colorado, a private consultant contracted by Molycorp.

The land-surface altitude was used to establish a datum for each observation well. A permanent measuring point for water-level measurement was established at each well, and the distance of this measuring point above land surface was determined. Description and distance above land surface of measuring points for Phase I and II wells are listed in table 4. Ground-water altitudes in observation wells were calculated by subtracting the depth to water below the permanent measuring point, minus the height of the permanent measur- 

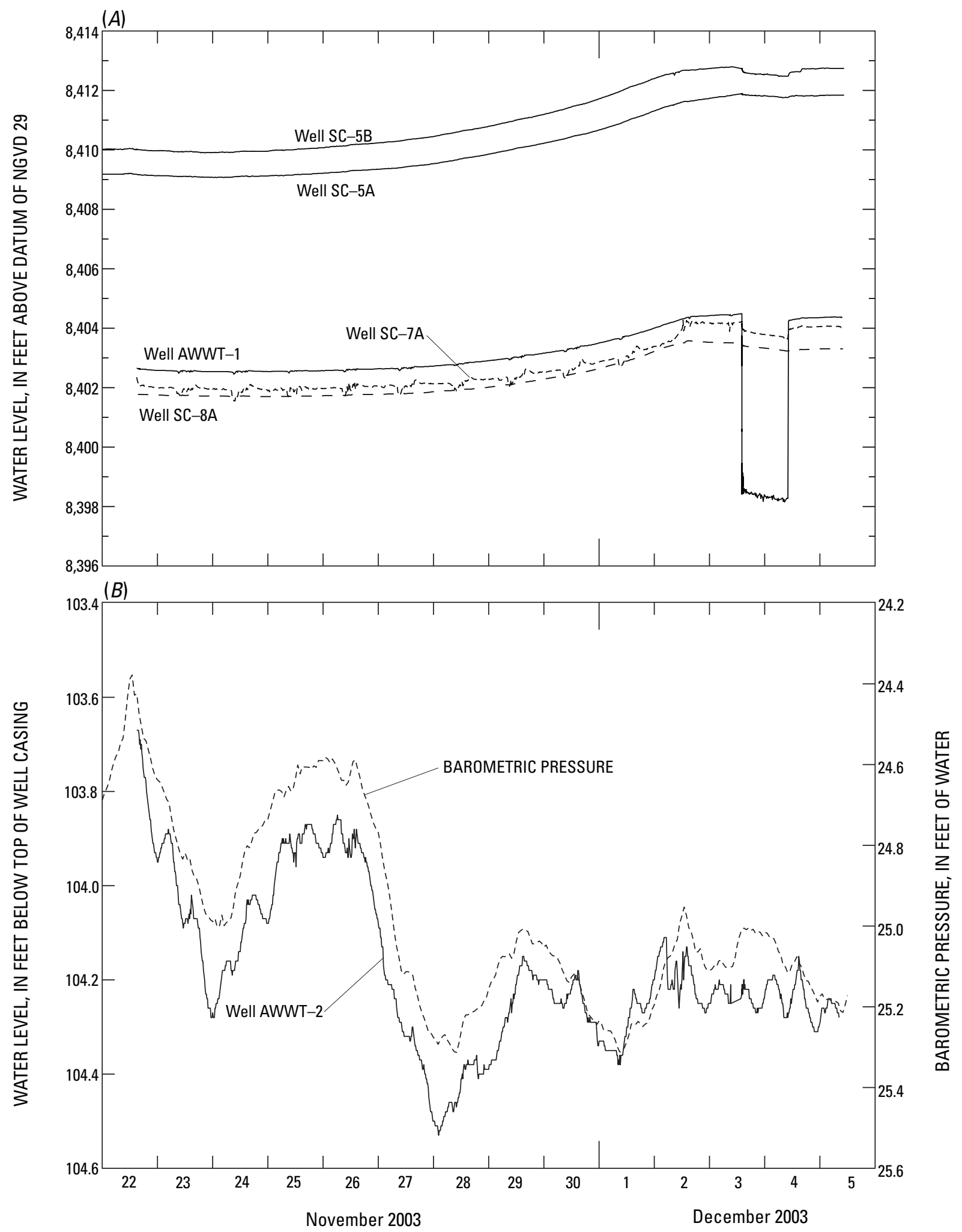

Figure 10. (A) Water levels in wells AWWT-1, SC-5A, SC-5B, SC-7A, and SC-8A before, during, and after pumping test and (B) comparison of water levels in well AWWT-2 to barometric pressure, November 22-December 5, 2003. 
Table 3. Results of pumping test conducted December 3-4, 2003, in selected wells in Red River Valley, north-central New Mexico.

\begin{tabular}{cccc}
\hline $\begin{array}{c}\text { Well } \\
\text { (fig. 3) }\end{array}$ & $\begin{array}{c}\text { Estimated transmissivity } \\
\text { (feet squared per day) }\end{array}$ & $\begin{array}{c}\text { Estimated saturated thickness } \\
\text { (feet) }\end{array}$ & $\begin{array}{c}\text { Estimated hydraulic conductivity } \\
\text { (feet per day) }\end{array}$ \\
\hline SC-5A & 12,000 & 52 & 230 \\
SC-7A & 34,000 & 99 & 340 \\
\hline
\end{tabular}

ing point above land surface, from the land-surface altitude. Water-level altitudes for Phase I and II wells are listed in table 4. Water levels in Phase I wells included in table 4 have not been previously published. Naus and others (2005) discuss water levels measured in Phase I wells during 2002 and 2003.

Water levels in the Phase II drilled wells SC-6A, SC-7A, SC-8A, and the Hottentot, Hansen, and La Bobita wells typically rose rapidly during the melting of the winter snowpack in the springtime and then generally declined during the rest of the year. The Red River streamflow hydrograph (fig. 11A) indicates that most meltwater from the winter snowpack entered the river during April and May. Water levels in these wells were measured periodically and, therefore, may not coincide precisely with the beginning and ending of waterlevel rises in response to spring snowmelt. The duration of water-level rise, however, appears to be typically about 2 months, after which a slow water-level decline occurs during the following 10 months.

Wells SC-6A, SC-7A and SC-8A are completed in unconsolidated deposits; well SC6-A is completed in debrisflow deposits, and wells SC-7A and SC-8A are most likely completed in mixed debris-flow deposits and Red River alluvium. Wells SC-6A, SC-7A, and SC-8A are about 2,200, 400, and $100 \mathrm{ft}$ north of the Red River, respectively.

In the Straight Creek drainage, the water-level rise in response to spring snowmelt occurred earlier and was smaller at greater distances from the Red River. The water level in well SC-6A rose $1.88 \mathrm{ft}$ between February 7 and April 15, 2003, and $1.85 \mathrm{ft}$ between February 20 and May 12, 2004 (fig. 11B); water levels in wells SC-7A and SC-8A rose 13.71 and $13.02 \mathrm{ft}$ between April 17 and June 5, 2003, and 14.00 and $13.56 \mathrm{ft}$ between March 26 and June 1, 2004, respectively (figs. $11 C$ and $11 D$ ). The springtime increases in water levels in wells SC7-A and SC-8A were about eight times larger than those in well SC-6A (fig. 11). The magnitude of subsequent water-level declines in wells SC-6A, SC-7A and SC-8A during the following approximately 10 months were similarly related to distance from the Red River (fig. 11). The water level in well SC-6A declined $1.73 \mathrm{ft}$ during the approximately 10 months between April 15, 2003, and February 20, 2004; water levels in wells SC-7A and SC-8A declined 12.71 and $12.05 \mathrm{ft}$, respectively, during the approximately 10 months between June 5, 2003, and March 26, 2004.

Well SC-9A is about $7 \mathrm{ft}$ from the north bank of the Red River and about $100 \mathrm{ft}$ south of well SC-8A (fig. 3). This well was dry at the time of construction but subsequently contained water. Three water levels in well SC-9A measured on March 26, May 12, and June 1, 2004, ranged from 12.02 to
$25.58 \mathrm{ft}$ above concurrently measured water levels in well SC8A. On May 12, 2004, the stage of the Red River was $31.5 \mathrm{ft}$ above the water level in well SC-8A and $16.2 \mathrm{ft}$ higher than the water level in well SC-9A. This substantially higher stage in the Red River compared with water levels in wells SC-8A and SC-9A, and the absence of water in well SC-9A and nearby holes at the time of completion of well SC-9A, indicate that the Red River had a poor hydraulic connection to the underlying ground-water system and the surface-water system is perched above the ground-water system at this site.

The Hottentot well, completed in debris-flow deposits, is about 1,700 ft north of the Red River and about $0.75 \mathrm{mi}$ upstream (east) from Straight Creek. The water level in the Hottentot well rose $1.69 \mathrm{ft}$ between February 5 and May 12, 2003, and $2.80 \mathrm{ft}$ between March 26 and May 12, 2004 (fig. 12A). The water level declined $0.77 \mathrm{ft}$ during the approximately 10 months between May 12, 2003, and March 26, 2004.

The Hansen well is completed in debris-flow deposits and is about $1,500 \mathrm{ft}$ north of the Red River and about $0.75 \mathrm{mi}$ downstream (west) from Straight Creek. The water level in the Hansen well rose $3.96 \mathrm{ft}$ between February 5 and April 17, 2003, and $2.83 \mathrm{ft}$ between February 20 and May 11, 2004 (fig. 12B). The water level declined $3.79 \mathrm{ft}$ during the approximately 10 months between measurements on April 17, 2003, and February 20, 2004.

The La Bobita well is completed in unconsolidated deposits not associated with debris-flow deposits. The well is about $600 \mathrm{ft}$ northwest of the Red River and about $2 \mathrm{mi}$ downstream (west) from Straight Creek. The water level in the La Bobita well rose $5.49 \mathrm{ft}$ between February 7 and May 15, 2003, and $4.68 \mathrm{ft}$ between March 26 and May 13, 2004 (fig. 12C). The water level declined $4.57 \mathrm{ft}$ during the approximately 10 months between measurements on May 15, 2003, and March 26, 2004.

Wells in Capulin Canyon are about 1 mi northeast of the Red River. Wells CC-1A and CC-2A are completed in Capulin Canyon alluvium, well $\mathrm{CC}-1 \mathrm{~B}$ is completed in bedrock or overlying regolith, and well $\mathrm{CC}-2 \mathrm{~B}$ is completed in bedrock. The hydrographs for each of these four wells are similar (fig. 13). A seasonal high in water level occurs during spring snowmelt in April or May 2003, a seasonal low in July 2003, and then a second seasonal high in September 2003. The spring seasonal high occurs again in April 2004. The range in water levels at wells $\mathrm{CC}-1 \mathrm{~A}$ and $\mathrm{CC}-2 \mathrm{~A}$ (completed in alluvium) were about 1.8 times the range in wells $\mathrm{CC}-1 \mathrm{~B}$ and $\mathrm{CC}-2 \mathrm{~B}$ (completed in regolith or bedrock), respectively (fig. 13). 

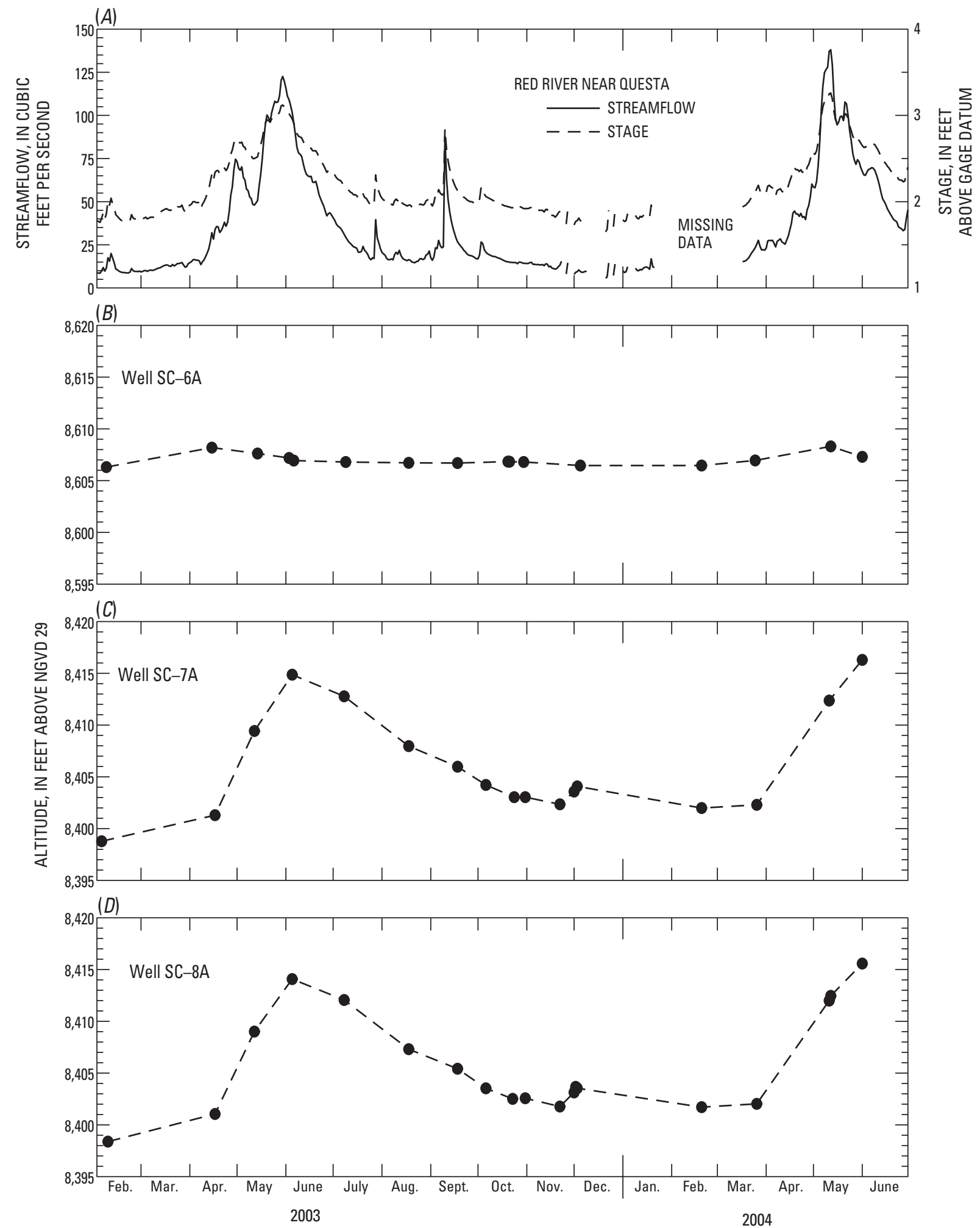

Figure 11. (A) Daily mean streamflow and stage of the Red River near Questa and $(B-D)$ ground-water altitudes in wells $S C-6 A$, SC-7A, and SC-8A, February 2003-June 2004. 


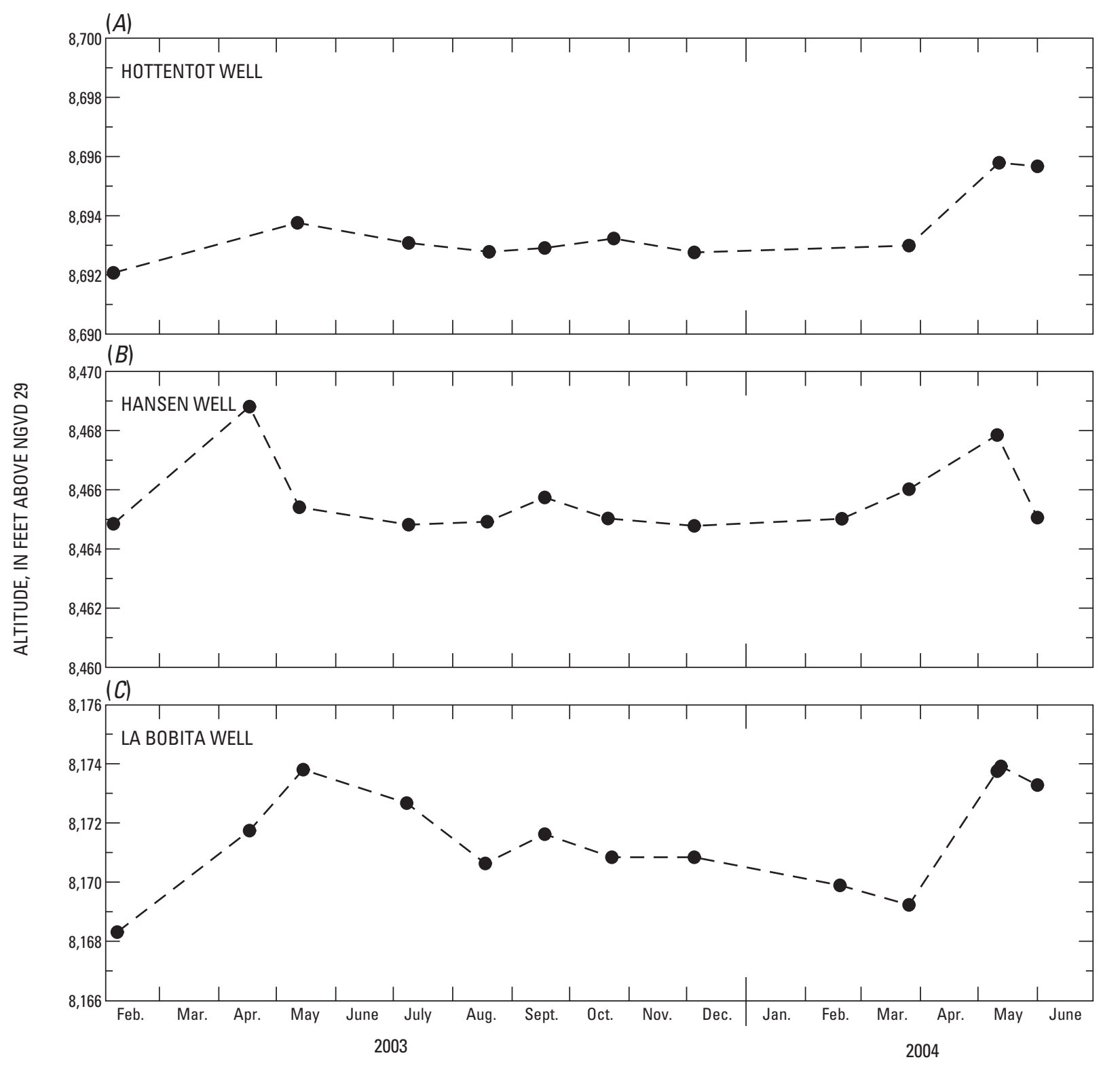

Figure 12. Ground-water altitudes in (A) Hottentot, (B) Hansen, and (C) La Bobita wells, February 2003-June 2004.

Phase III wells were installed in unconsolidated material along an approximately 1-mi reach of the Red River west of Elephant Rock campground (figs. 1 and 4). These wells were installed to examine the interaction of the Red River and water in the Red River alluvium. Water levels in these wells were measured in December 2003 and in February, March, May, and June 2004. The difference in altitude between the water level in these wells and the stage of the Red River also was determined from survey data collected in May and June 2004. Water-level altitudes in the Phase II La Bobita well and all Phase III wells and altitude of the stage of the Red River are listed in table 5; a comparison of water levels in the La Bobita well and Phase III wells with the stage of the Red River is shown in figure 14.

Well 1 was installed about $150 \mathrm{ft}$ downstream (west) from a line approximately perpendicular to the Red River and connecting to the La Bobita well (fig. 4). Water levels measured in May and June 2004 in the La Bobita well ranged from 2.95 to $3.52 \mathrm{ft}$ higher than concurrently measured water levels in well 1 (fig. 14, table 5). Considering the locations of these two wells, the relative water levels indicate that ground water is flowing toward the Red River. The stage of the Red River also was measured in May and June 2004 where a line approximately perpendicular to the bank of the river intersects the La Bobita well. Ground-water levels in the La Bobita well ranged from 7.1 to $6.7 \mathrm{ft}$ lower and in well 1 ranged from 10.1 to $9.8 \mathrm{ft}$ lower than the stage of the Red River (fig. 14, table 5). This indicates that, near these wells, the Red River is perched above the water table and may be disconnected from or have a poor hydraulic connection to the underlying ground water. 


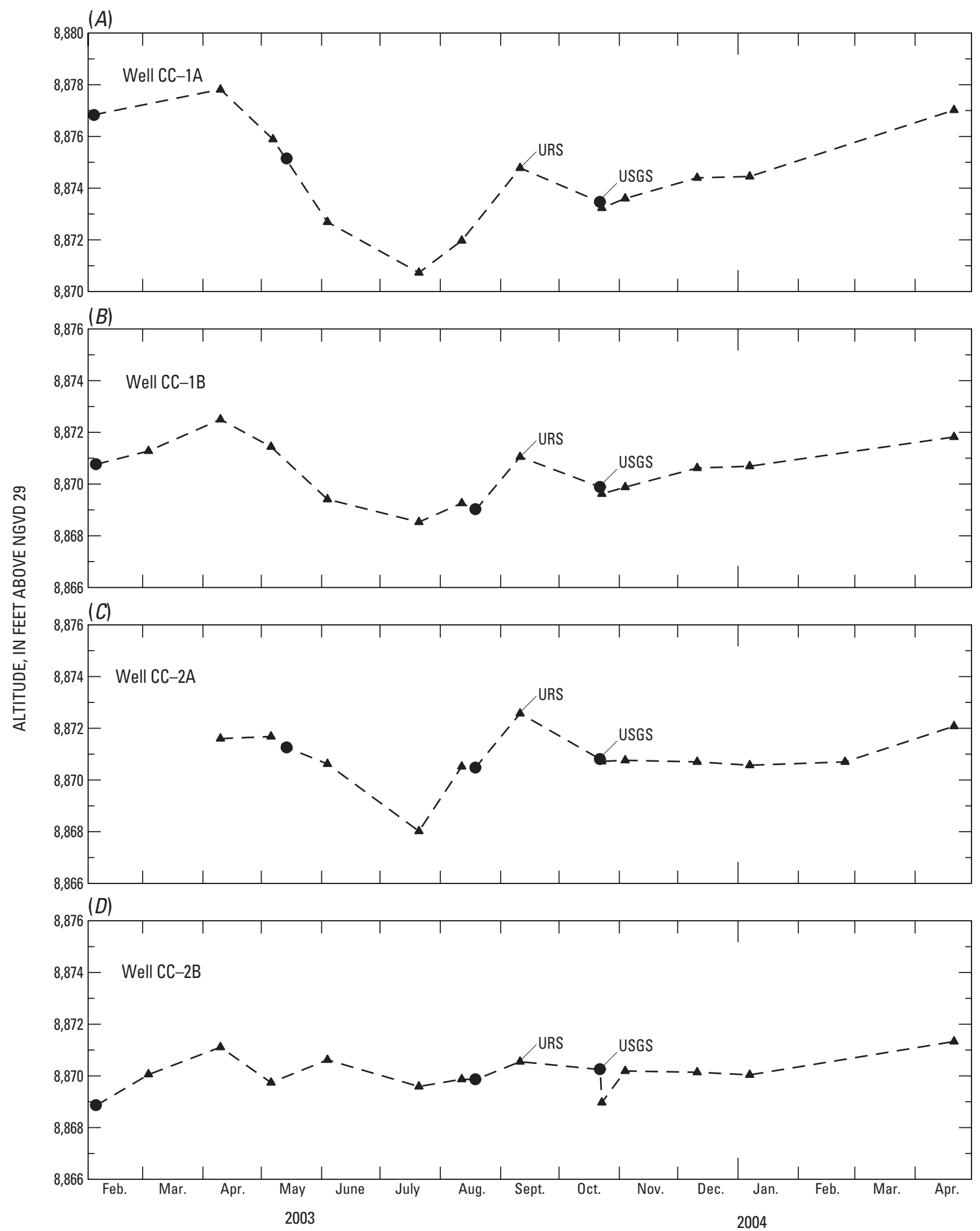

Figure 13. Ground-water altitudes in wells (A)CC-1A, (B) CC-1B, (C)CC-2A, and (D) CC-2B, February 2003-April 2004. Data collected by URS, Denver, Colorado, and U.S. Geological Survey (USGS) personnel. 
Table 4. Altitude of water levels in Phase I and II wells and existing Advanced Wastewater Treatment Facility wells, Red River Valley, north-central New Mexico, 2002-04.

[Shaded rows indicate water-level measurements obtained by URS, Denver, Colorado. NGVD 29, National Geodetic Vertical Datum of 1929]

\begin{tabular}{|c|c|c|c|c|c|c|c|c|c|}
\hline $\begin{array}{l}\text { Well } \\
\text { identifi- } \\
\text { cation } \\
\text { (figs. 2-5) }\end{array}$ & $\begin{array}{c}\text { Date } \\
\text { (month/ } \\
\text { day/year) }\end{array}$ & $\begin{array}{l}\text { Measuring point } \\
\text { (permanent } \\
\text { measuring point if } \\
\text { no correction) }\end{array}$ & $\begin{array}{c}\text { Depth to } \\
\text { water } \\
\text { (feet below } \\
\text { measuring } \\
\text { point) }\end{array}$ & $\begin{array}{l}\text { Measu- } \\
\text { ring point } \\
\text { correction } \\
\text { (feet) }^{1}\end{array}$ & $\begin{array}{c}\text { Depth to } \\
\text { water } \\
\text { (feet below } \\
\text { permanent } \\
\text { measuring } \\
\quad \text { point) }\end{array}$ & $\begin{array}{l}\text { Measuring } \\
\text { point height } \\
\text { above land } \\
\text { surface } \\
\text { (feet) }\end{array}$ & $\begin{array}{l}\text { Depth to } \\
\text { water } \\
\text { (feet below } \\
\text { land } \\
\text { surface) }\end{array}$ & $\begin{array}{l}\text { Land } \\
\text { surface } \\
\text { altitude } \\
\text { (feet above } \\
\text { NGVD 29) }\end{array}$ & $\begin{array}{c}\text { Altitude } \\
\text { of water } \\
\text { level (feet } \\
\text { above } \\
\text { NGVD 29) }\end{array}$ \\
\hline \multicolumn{10}{|c|}{ Phase I wells } \\
\hline $\mathrm{SC}-1 \mathrm{~A}$ & $03 / 18 / 02$ & Top of casing & 52.51 & +0.12 & 52.39 & 2.88 & 49.51 & $8,904.44$ & $8,854.94$ \\
\hline $\mathrm{SC}-1 \mathrm{~A}$ & $03 / 26 / 02$ & Access hole in cap & 52.32 & 0.00 & 52.32 & 2.88 & 49.44 & $8,904.44$ & $8,855.00$ \\
\hline $\mathrm{SC}-1 \mathrm{~A}$ & $04 / 25 / 02$ & Access hole in cap & 52.44 & 0.00 & 52.44 & 2.88 & 49.56 & $8,904.44$ & $8,854.88$ \\
\hline $\mathrm{SC}-1 \mathrm{~A}$ & $05 / 22 / 02$ & Access hole in cap & 52.65 & 0.00 & 52.65 & 2.88 & 49.77 & $8,904.44$ & $8,854.67$ \\
\hline $\mathrm{SC}-1 \mathrm{~A}$ & $08 / 21 / 02$ & Access hole in cap & 52.48 & 0.00 & 52.48 & 2.88 & 49.60 & $8,904.44$ & $8,854.84$ \\
\hline $\mathrm{SC}-1 \mathrm{~A}$ & 09/17/02 & Access hole in cap & 52.71 & 0.00 & 52.71 & 2.88 & 49.83 & $8,904.44$ & $8,854.61$ \\
\hline $\mathrm{SC}-1 \mathrm{~A}$ & $10 / 16 / 02$ & Access hole in cap & 51.94 & 0.00 & 51.94 & 2.88 & 49.06 & $8,904.44$ & $8,855.38$ \\
\hline $\mathrm{SC}-1 \mathrm{~A}$ & $11 / 14 / 02$ & Access hole in cap & 52.30 & 0.00 & 52.30 & 2.88 & 49.42 & $8,904.44$ & $8,855.02$ \\
\hline $\mathrm{SC}-1 \mathrm{~A}$ & $12 / 12 / 02$ & Access hole in cap & 52.39 & 0.00 & 52.39 & 2.88 & 49.51 & $8,904.44$ & $8,854.93$ \\
\hline $\mathrm{SC}-1 \mathrm{~A}$ & 02/03/03 & Access hole in cap & 52.61 & 0.00 & 52.61 & 2.88 & 49.73 & $8,904.44$ & $8,854.71$ \\
\hline $\mathrm{SC}-1 \mathrm{~A}$ & $04 / 16 / 03$ & Access hole in cap & 51.50 & 0.00 & 51.50 & 2.88 & 48.62 & $8,904.44$ & $8,855.82$ \\
\hline $\mathrm{SC}-1 \mathrm{~A}$ & 09/18/03 & Access hole in cap & 51.99 & 0.00 & 51.99 & 2.88 & 49.11 & $8,904.44$ & $8,855.33$ \\
\hline $\mathrm{SC}-1 \mathrm{~A}$ & $10 / 20 / 03$ & Access hole in cap & 52.45 & 0.00 & 52.45 & 2.88 & 49.57 & $8,904.44$ & $8,854.87$ \\
\hline $\mathrm{SC}-1 \mathrm{~A}$ & $10 / 23 / 03$ & Access hole in cap & 52.48 & 0.00 & 52.48 & 2.88 & 49.60 & $8,904.44$ & $8,854.84$ \\
\hline $\mathrm{SC}-1 \mathrm{~A}$ & $12 / 05 / 03$ & Access hole in cap & 52.61 & 0.00 & 52.61 & 2.88 & 49.73 & $8,904.44$ & $8,854.71$ \\
\hline $\mathrm{SC}-1 \mathrm{~A}$ & $02 / 21 / 04$ & Access hole in cap & 52.61 & 0.00 & 52.61 & 2.88 & 49.73 & $8,904.44$ & $8,854.71$ \\
\hline $\mathrm{SC}-1 \mathrm{~A}$ & $03 / 26 / 04$ & Access hole in cap & 51.58 & 0.00 & 51.58 & 2.88 & 48.70 & $8,904.44$ & $8,855.74$ \\
\hline $\mathrm{SC}-1 \mathrm{~A}$ & 05/11/04 & Access hole in cap & 51.45 & 0.00 & 51.45 & 2.88 & 48.57 & $8,904.44$ & $8,855.87$ \\
\hline $\mathrm{SC}-1 \mathrm{~A}$ & 06/01/04 & Access hole in cap & 52.45 & 0.00 & 52.45 & 2.88 & 49.57 & $8,904.44$ & $8,854.87$ \\
\hline $\mathrm{SC}-1 \mathrm{~B}$ & $03 / 15 / 02$ & Top of casing & 59.02 & +0.12 & 58.90 & 3.15 & 55.75 & $8,901.88$ & $8,846.13$ \\
\hline $\mathrm{SC}-1 \mathrm{~B}$ & 03/18/02 & Top of casing & 59.01 & +0.12 & 58.89 & 3.15 & 55.74 & $8,901.88$ & $8,846.14$ \\
\hline $\mathrm{SC}-1 \mathrm{~B}$ & 03/26/02 & Access hole in cap & 58.88 & 0.00 & 58.88 & 3.15 & 55.73 & $8,901.88$ & $8,846.15$ \\
\hline
\end{tabular}


Table 4. Altitude of water levels in Phase I and II wells and existing Advanced Wastewater Treatment Facility wells, Red River Valley, north-central New Mexico, 2002-04. - Continued

[Shaded rows indicate water-level measurements obtained by URS, Denver, Colorado. NGVD 29, National Geodetic Vertical Datum of 1929]

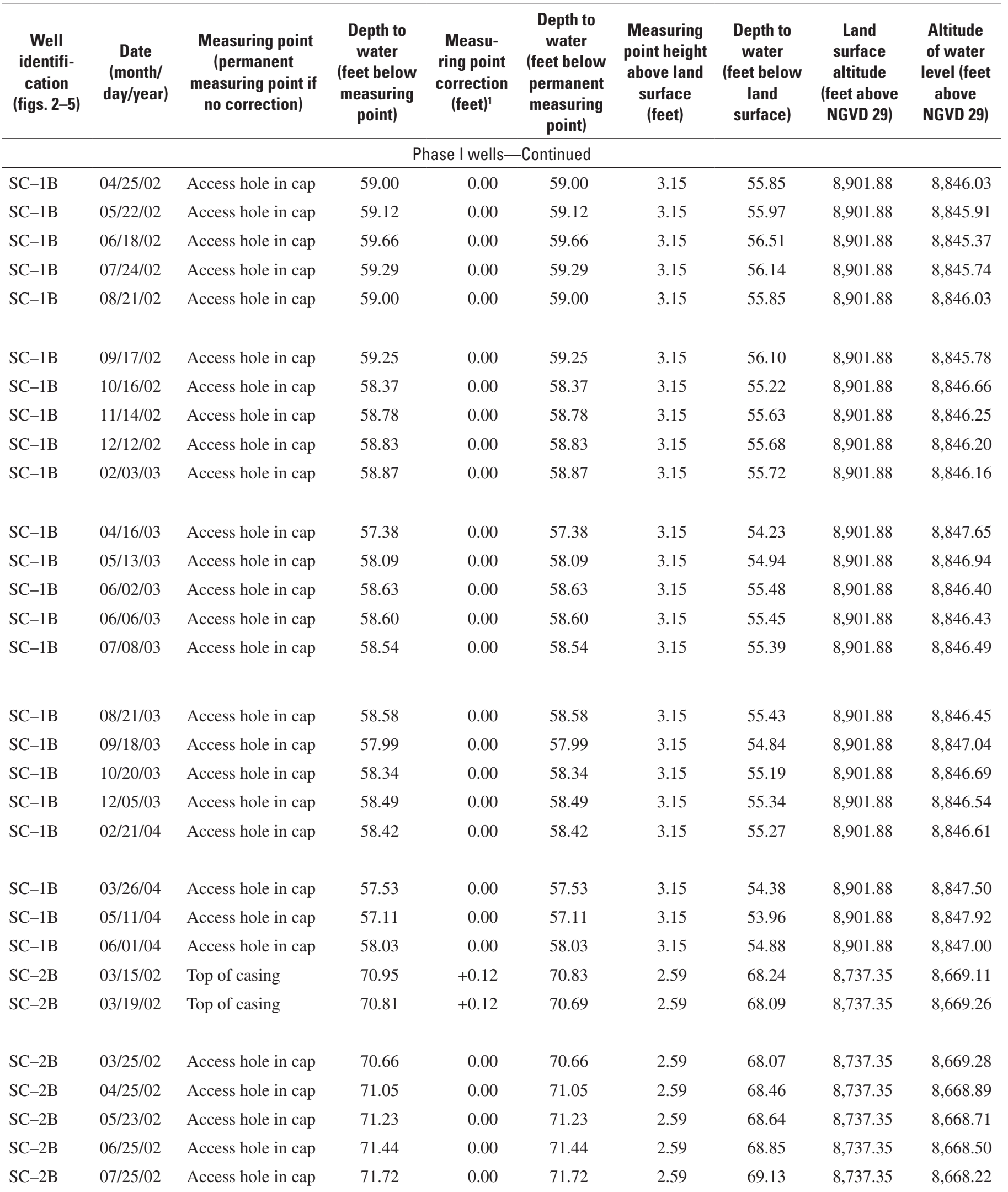


Table 4. Altitude of water levels in Phase I and II wells and existing Advanced Wastewater Treatment Facility wells, Red River Valley, north-central New Mexico, 2002-04.-Continued

[Shaded rows indicate water-level measurements obtained by URS, Denver, Colorado. NGVD 29, National Geodetic Vertical Datum of 1929]

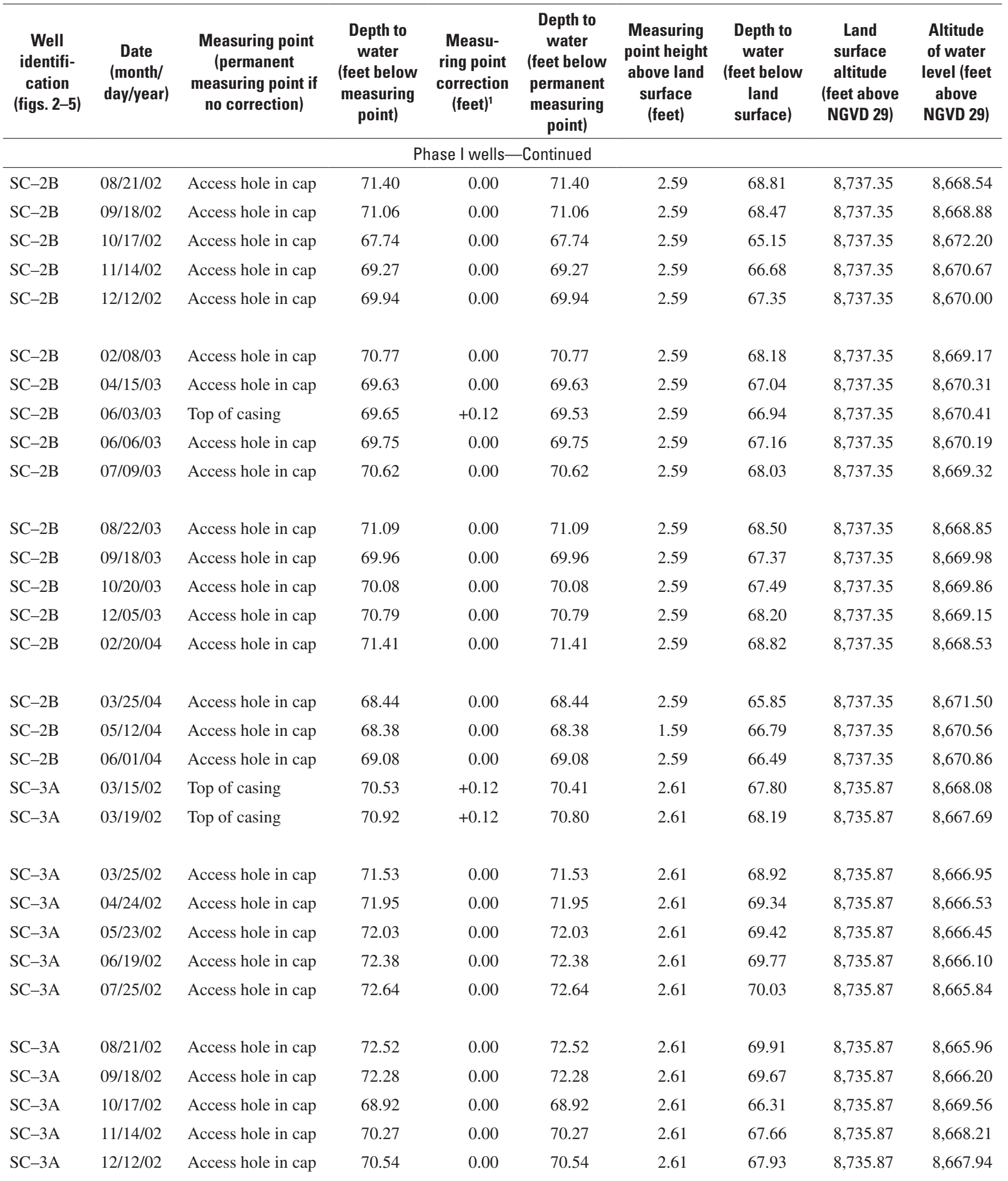


Table 4. Altitude of water levels in Phase I and II wells and existing Advanced Wastewater Treatment Facility wells, Red River Valley, north-central New Mexico, 2002-04. - Continued

[Shaded rows indicate water-level measurements obtained by URS, Denver, Colorado. NGVD 29, National Geodetic Vertical Datum of 1929]

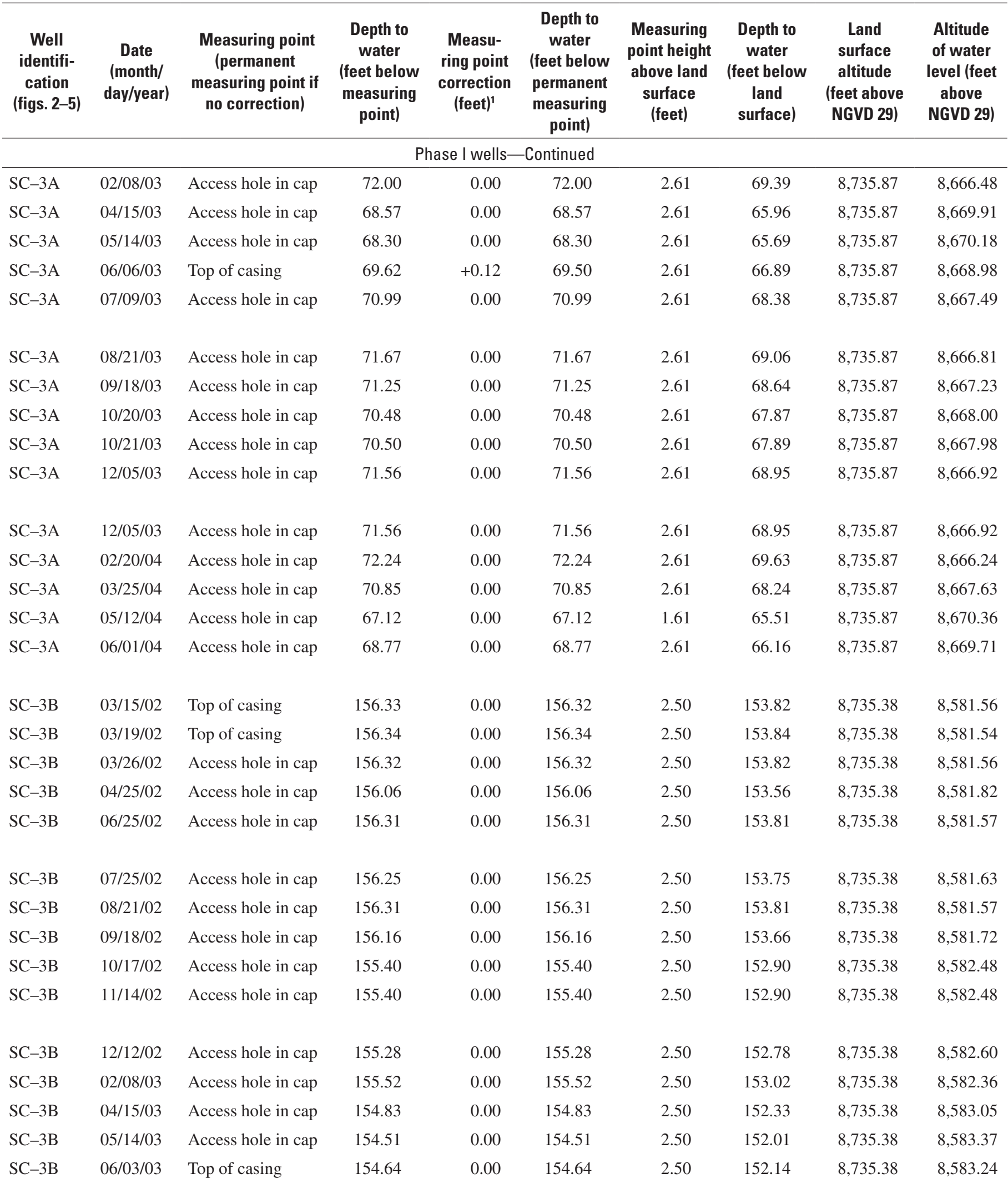


Table 4. Altitude of water levels in Phase I and II wells and existing Advanced Wastewater Treatment Facility wells, Red River Valley, north-central New Mexico, 2002-04.-Continued

[Shaded rows indicate water-level measurements obtained by URS, Denver, Colorado. NGVD 29, National Geodetic Vertical Datum of 1929]

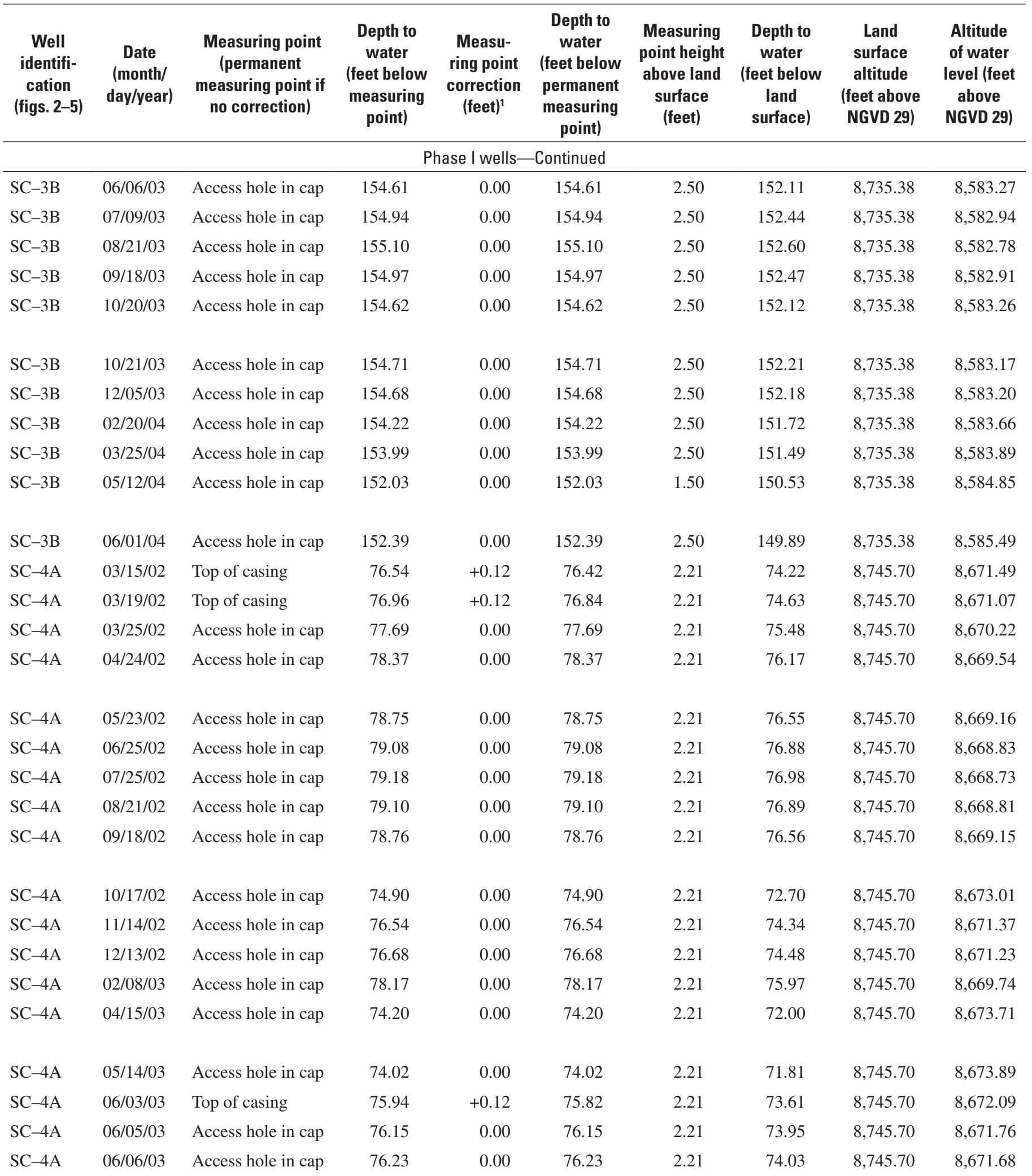


Table 4. Altitude of water levels in Phase I and II wells and existing Advanced Wastewater Treatment Facility wells, Red River Valley, north-central New Mexico, 2002-04.-Continued

[Shaded rows indicate water-level measurements obtained by URS, Denver, Colorado. NGVD 29, National Geodetic Vertical Datum of 1929]

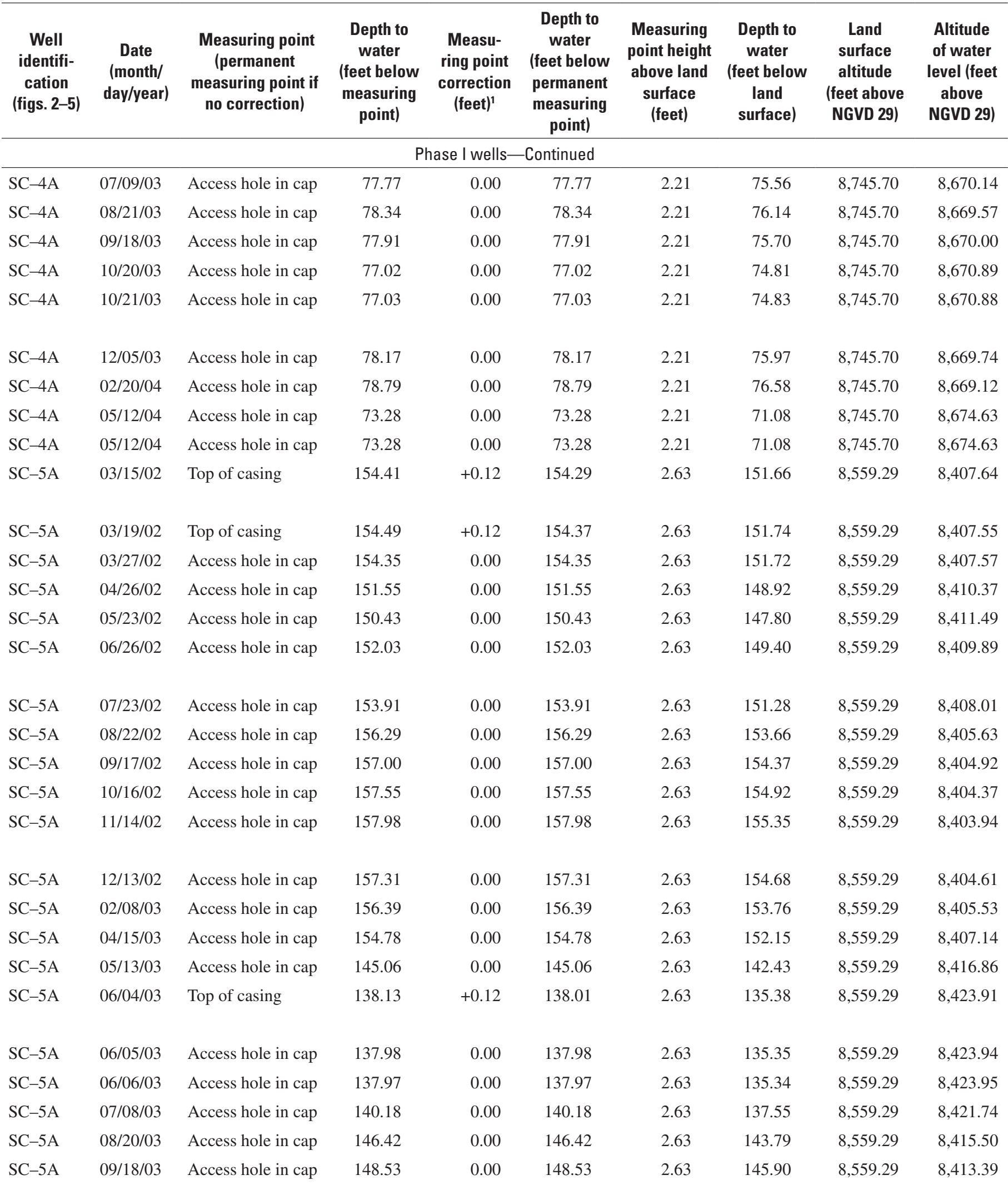


Table 4. Altitude of water levels in Phase I and II wells and existing Advanced Wastewater Treatment Facility wells, Red River Valley, north-central New Mexico, 2002-04.-Continued

[Shaded rows indicate water-level measurements obtained by URS, Denver, Colorado. NGVD 29, National Geodetic Vertical Datum of 1929]

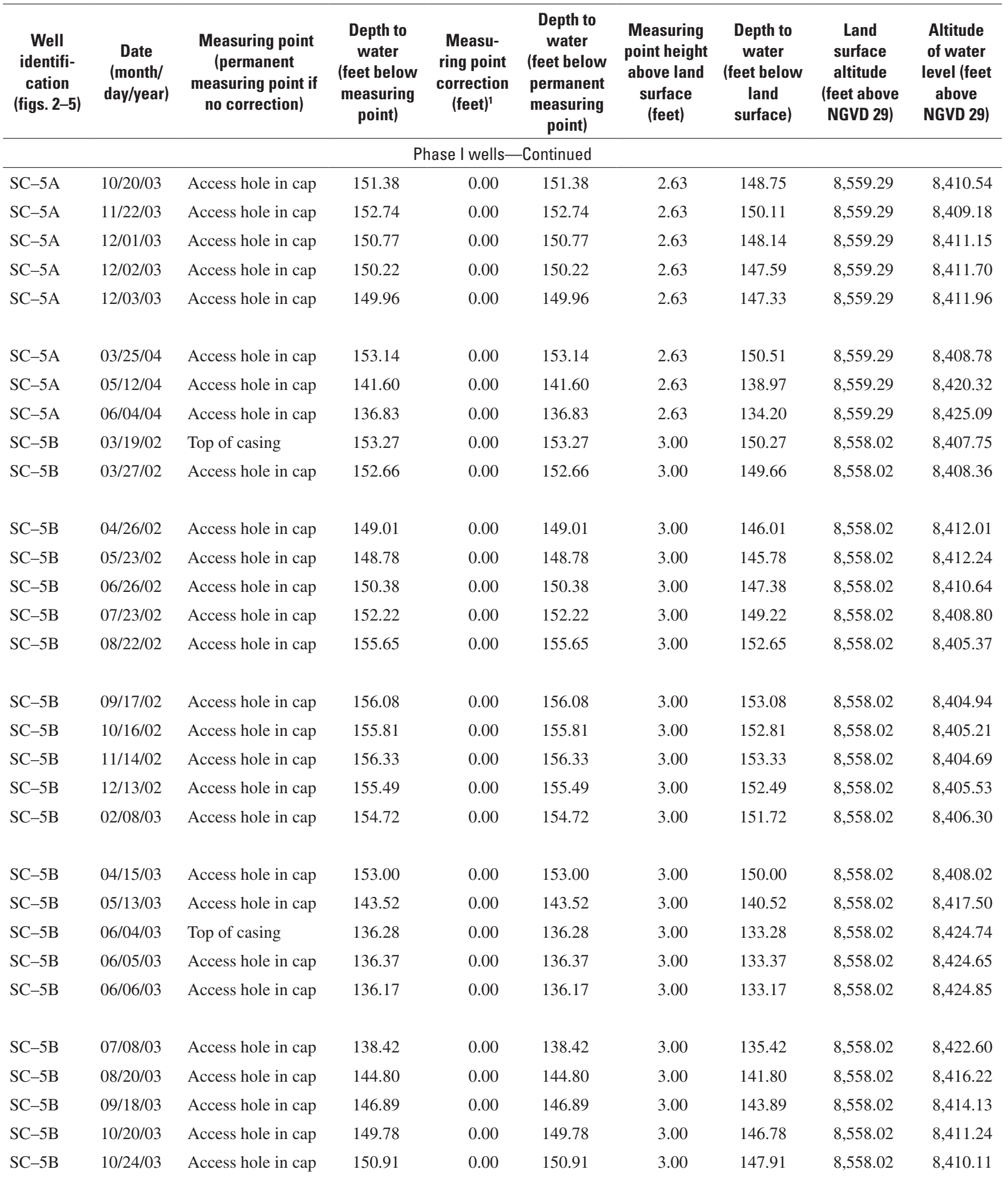


Table 4. Altitude of water levels in Phase I and II wells and existing Advanced Wastewater Treatment Facility wells, Red River Valley, north-central New Mexico, 2002-04. - Continued

[Shaded rows indicate water-level measurements obtained by URS, Denver, Colorado. NGVD 29, National Geodetic Vertical Datum of 1929]

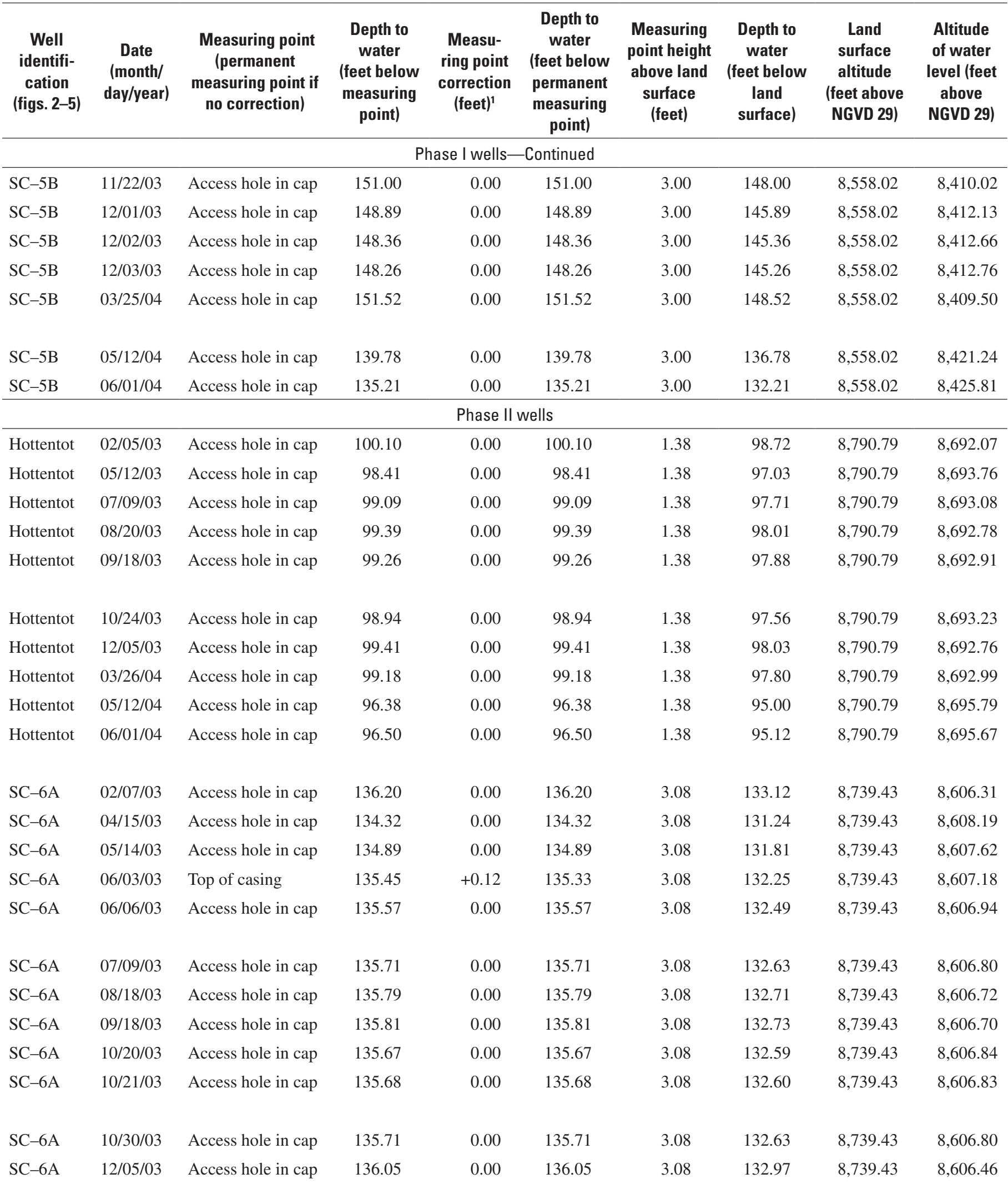


Table 4. Altitude of water levels in Phase I and II wells and existing Advanced Wastewater Treatment Facility wells, Red River Valley, north-central New Mexico, 2002-04.-Continued

[Shaded rows indicate water-level measurements obtained by URS, Denver, Colorado. NGVD 29, National Geodetic Vertical Datum of 1929]

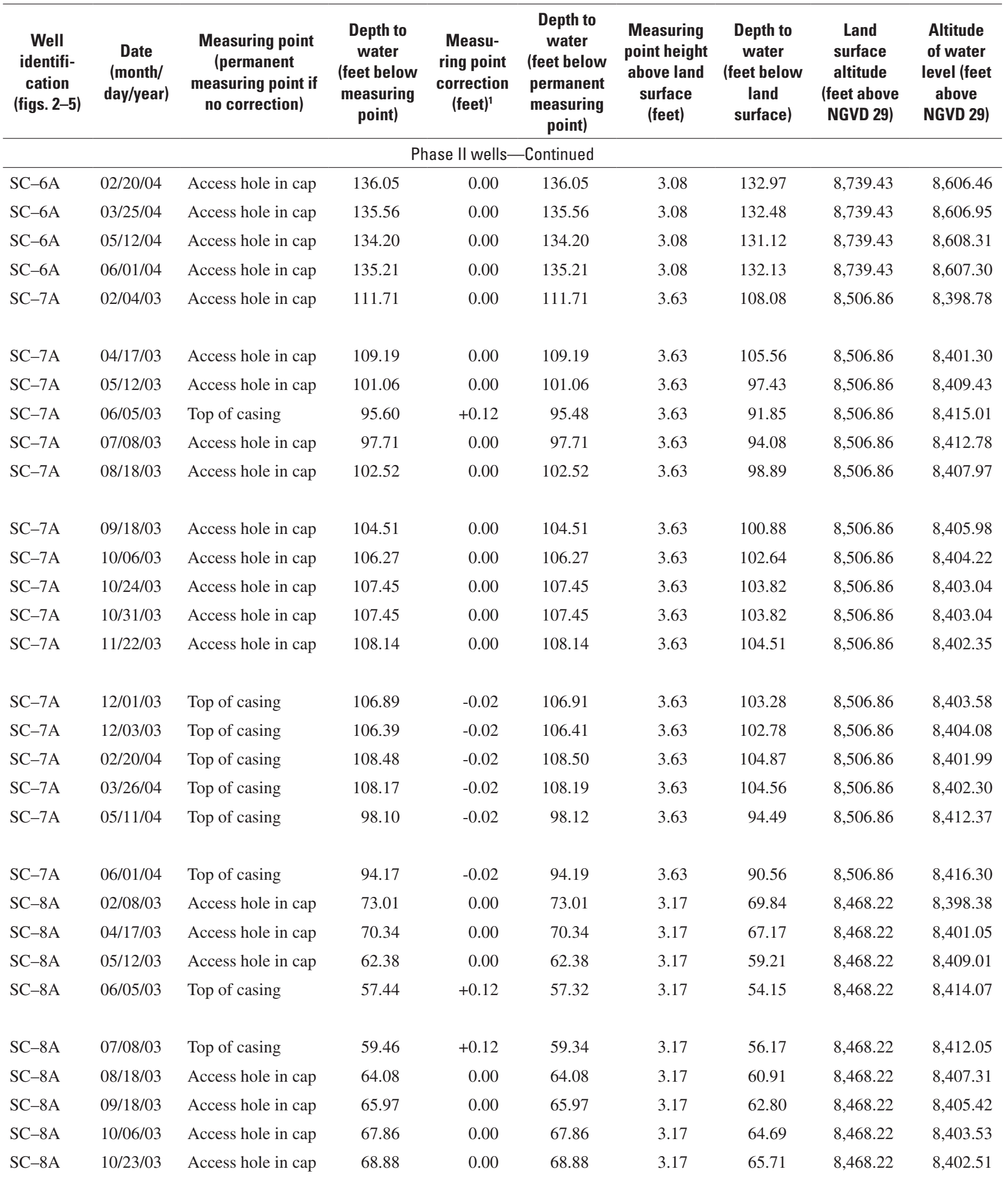


Table 4. Altitude of water levels in Phase I and II wells and existing Advanced Wastewater Treatment Facility wells, Red River Valley, north-central New Mexico, 2002-04. - Continued

[Shaded rows indicate water-level measurements obtained by URS, Denver, Colorado. NGVD 29, National Geodetic Vertical Datum of 1929]

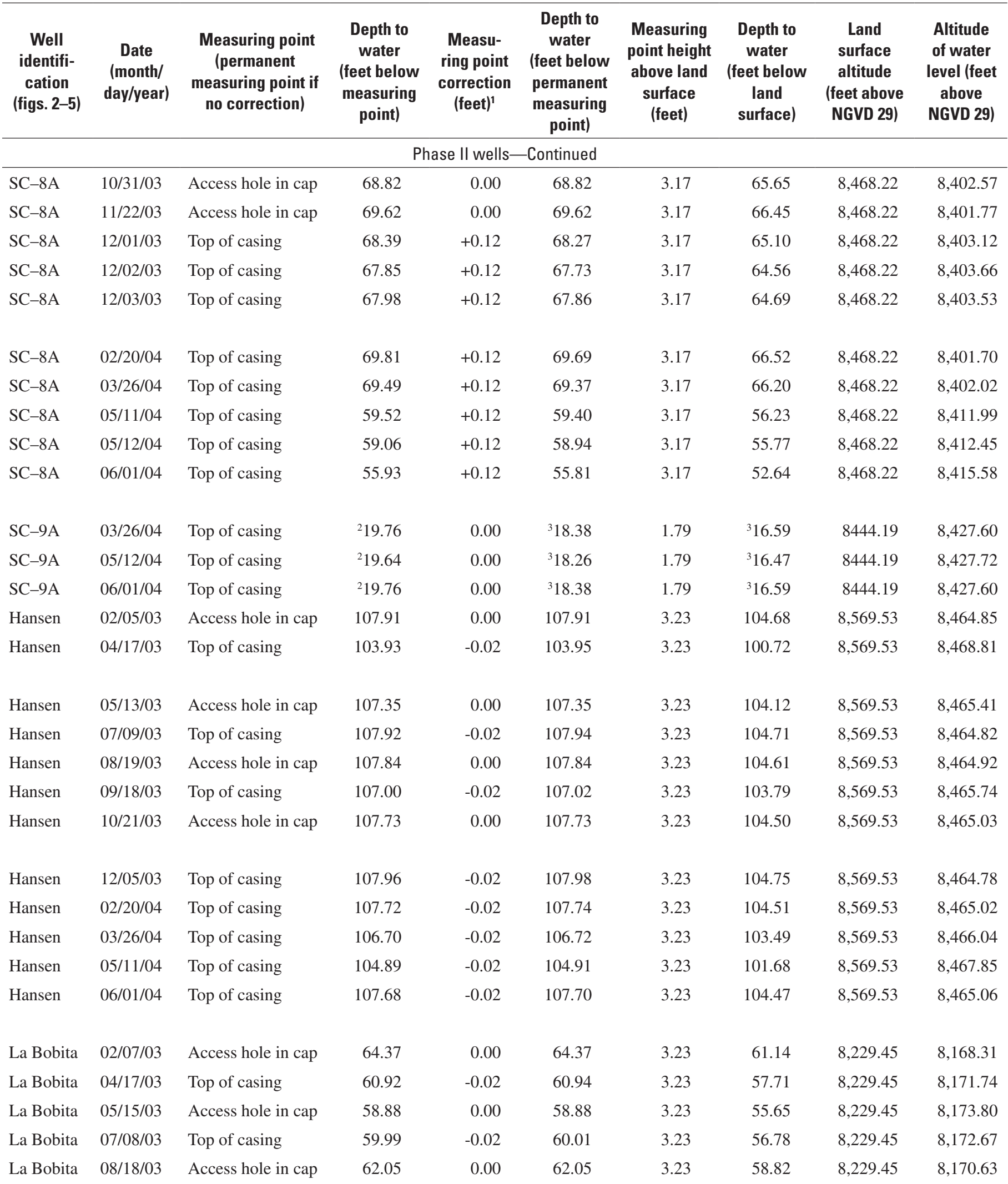


Table 4. Altitude of water levels in Phase I and II wells and existing Advanced Wastewater Treatment Facility wells, Red River Valley, north-central New Mexico, 2002-04.-Continued

[Shaded rows indicate water-level measurements obtained by URS, Denver, Colorado. NGVD 29, National Geodetic Vertical Datum of 1929]

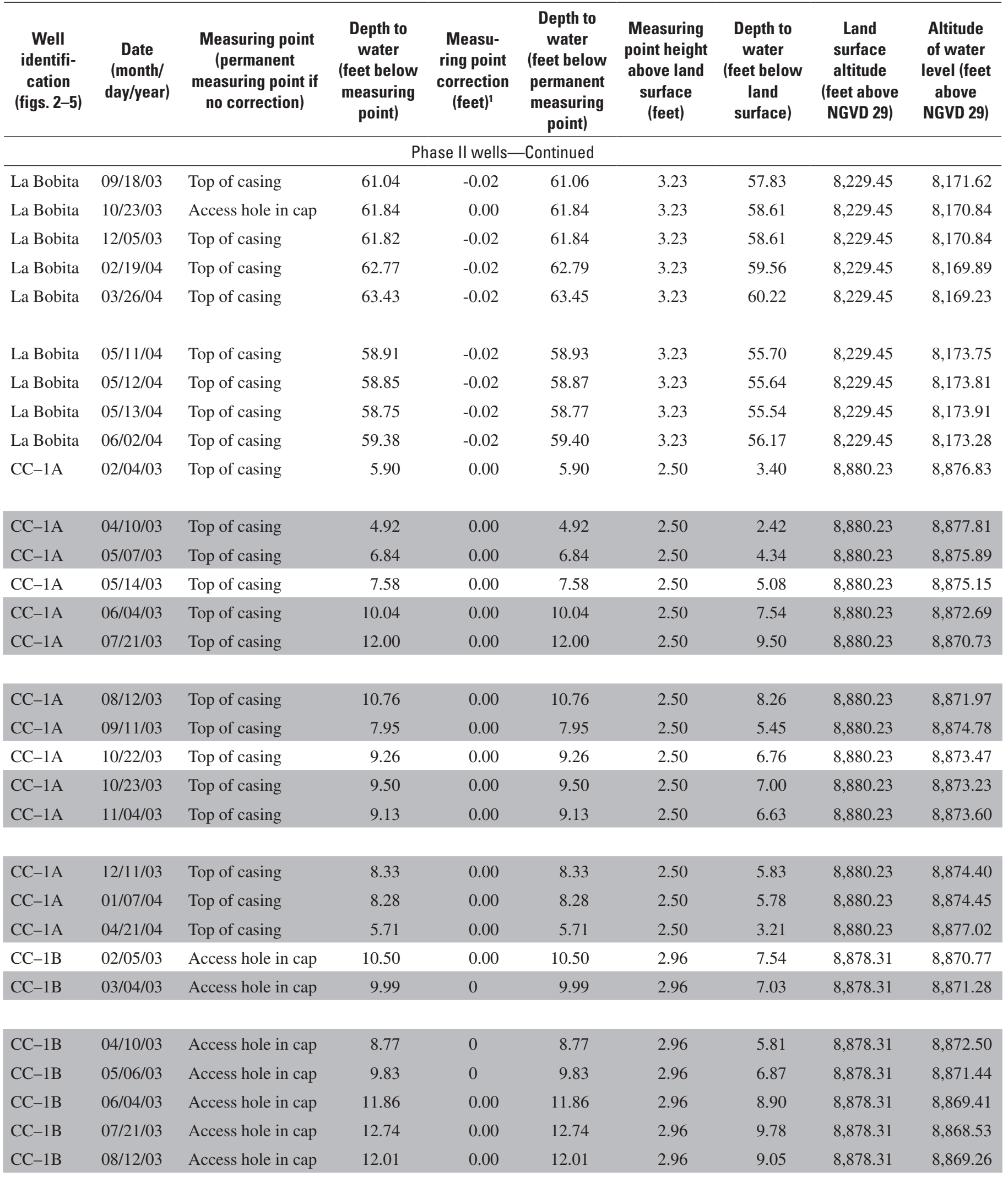


Table 4. Altitude of water levels in Phase I and II wells and existing Advanced Wastewater Treatment Facility wells, Red River Valley, north-central New Mexico, 2002-04. - Continued

[Shaded rows indicate water-level measurements obtained by URS, Denver, Colorado. NGVD 29, National Geodetic Vertical Datum of 1929]

\begin{tabular}{|c|c|c|c|c|c|c|c|c|c|}
\hline $\begin{array}{c}\text { Well } \\
\text { identifi- } \\
\text { cation } \\
\text { (figs. 2-5) }\end{array}$ & $\begin{array}{c}\text { Date } \\
\text { (month/ } \\
\text { day/year) }\end{array}$ & $\begin{array}{l}\text { Measuring point } \\
\text { (permanent } \\
\text { measuring point if } \\
\text { no correction) }\end{array}$ & $\begin{array}{c}\text { Depth to } \\
\text { water } \\
\text { (feet below } \\
\text { measuring } \\
\text { point) }\end{array}$ & $\begin{array}{l}\text { Measu- } \\
\text { ring point } \\
\text { correction } \\
\text { (feet) }\end{array}$ & $\begin{array}{c}\text { Depth to } \\
\text { water } \\
\text { (feet below } \\
\text { permanent } \\
\text { measuring } \\
\text { point) }\end{array}$ & $\begin{array}{l}\text { Measuring } \\
\text { point height } \\
\text { above land } \\
\text { surface } \\
\text { (feet) }\end{array}$ & $\begin{array}{l}\text { Depth to } \\
\text { water } \\
\text { (feet below } \\
\text { land } \\
\text { surface) }\end{array}$ & $\begin{array}{c}\text { Land } \\
\text { surface } \\
\text { altitude } \\
\text { (feet above } \\
\text { NGVD 29) }\end{array}$ & $\begin{array}{c}\text { Altitude } \\
\text { of water } \\
\text { level (feet } \\
\text { above } \\
\text { NGVD 29) }\end{array}$ \\
\hline \multicolumn{10}{|c|}{ Phase II wells_-Continued } \\
\hline $\mathrm{CC}-1 \mathrm{~B}$ & $08 / 19 / 03$ & Access hole in cap & 12.24 & 0.00 & 12.24 & 2.96 & 9.28 & $8,878.31$ & $8,869.03$ \\
\hline $\mathrm{CC}-1 \mathrm{~B}$ & $09 / 11 / 03$ & Access hole in cap & 10.22 & 0.00 & 10.22 & 2.96 & 7.26 & $8,878.31$ & $8,871.05$ \\
\hline $\mathrm{CC}-1 \mathrm{~B}$ & $10 / 22 / 03$ & Access hole in cap & 11.38 & 0.00 & 11.38 & 2.96 & 8.42 & $8,878.31$ & $8,869.89$ \\
\hline $\mathrm{CC}-1 \mathrm{~B}$ & $10 / 23 / 03$ & Access hole in cap & 11.65 & 0.00 & 11.65 & 2.96 & 8.69 & $8,878.31$ & $8,869.62$ \\
\hline $\mathrm{CC}-1 \mathrm{~B}$ & $11 / 04 / 03$ & Access hole in cap & 11.39 & 0.00 & 11.39 & 2.96 & 8.43 & $8,878.31$ & $8,869.88$ \\
\hline $\mathrm{CC}-1 \mathrm{~B}$ & $12 / 11 / 03$ & Access hole in cap & 10.65 & 0.00 & 10.65 & 2.96 & 7.69 & $8,878.31$ & $8,870.62$ \\
\hline $\mathrm{CC}-1 \mathrm{~B}$ & $01 / 07 / 04$ & Access hole in cap & 10.58 & 0.00 & 10.58 & 2.96 & 7.62 & $8,878.31$ & $8,870.69$ \\
\hline $\mathrm{CC}-1 \mathrm{~B}$ & $04 / 21 / 04$ & Access hole in cap & 9.45 & 0.00 & 9.45 & 2.96 & 6.49 & $8,878.31$ & $8,871.82$ \\
\hline $\mathrm{CC}-2 \mathrm{~A}$ & $04 / 10 / 03$ & Top of casing & 8.42 & 0.00 & 8.42 & 4.00 & 4.42 & $8,876.02$ & $8,871.60$ \\
\hline $\mathrm{CC}-2 \mathrm{~A}$ & $05 / 06 / 03$ & Top of casing & 8.34 & 0.00 & 8.34 & 4.00 & 4.34 & $8,876.02$ & $8,871.68$ \\
\hline $\mathrm{CC}-2 \mathrm{~A}$ & $05 / 14 / 03$ & Top of casing & 8.76 & 0.00 & 8.76 & 4.00 & 4.76 & $8,876.02$ & $8,871.26$ \\
\hline $\mathrm{CC}-2 \mathrm{~A}$ & $06 / 04 / 03$ & Top of casing & 9.40 & 0.00 & 9.40 & 4.00 & 5.40 & $8,876.02$ & $8,870.62$ \\
\hline $\mathrm{CC}-2 \mathrm{~A}$ & $07 / 21 / 03$ & Top of casing & 12.00 & 0.00 & 12.00 & 4.00 & 8.00 & $8,876.02$ & $8,868.02$ \\
\hline $\mathrm{CC}-2 \mathrm{~A}$ & $08 / 12 / 03$ & Top of casing & 9.50 & 0.00 & 9.50 & 4.00 & 5.50 & $8,876.02$ & $8,870.52$ \\
\hline $\mathrm{CC}-2 \mathrm{~A}$ & 08/19/03 & Top of casing & 9.54 & 0.00 & 9.54 & 4.00 & 5.54 & $8,876.02$ & $8,870.48$ \\
\hline $\mathrm{CC}-2 \mathrm{~A}$ & $09 / 11 / 03$ & Top of casing & 7.45 & 0 & 7.45 & 4.00 & 3.45 & $8,876.02$ & $8,872.57$ \\
\hline $\mathrm{CC}-2 \mathrm{~A}$ & $10 / 22 / 03$ & Top of casing & 9.21 & 0.00 & 9.21 & 4.00 & 5.21 & $8,876.02$ & $8,870.81$ \\
\hline $\mathrm{CC}-2 \mathrm{~A}$ & $10 / 23 / 03$ & Top of casing & 9.30 & 0.00 & 9.30 & 4.00 & 5.30 & $8,876.02$ & $8,870.72$ \\
\hline $\mathrm{CC}-2 \mathrm{~A}$ & $11 / 04 / 03$ & Top of casing & 9.26 & 0.00 & 9.26 & 4.00 & 5.26 & $8,876.02$ & $8,870.76$ \\
\hline $\mathrm{CC}-2 \mathrm{~A}$ & $12 / 11 / 03$ & Top of casing & 9.32 & 0.00 & 9.32 & 4.00 & 5.32 & $8,876.02$ & $8,870.70$ \\
\hline $\mathrm{CC}-2 \mathrm{~A}$ & 01/07/04 & Top of casing & 9.45 & 0.00 & 9.45 & 4.00 & 5.45 & $8,876.02$ & $8,870.57$ \\
\hline $\mathrm{CC}-2 \mathrm{~A}$ & $02 / 25 / 04$ & Top of casing & 9.32 & 0.00 & 9.32 & 4.00 & 5.32 & $8,876.02$ & $8,870.70$ \\
\hline $\mathrm{CC}-2 \mathrm{~A}$ & $04 / 21 / 04$ & Top of casing & 7.94 & 0.00 & 7.94 & 4.00 & 3.94 & $8,876.02$ & $8,872.08$ \\
\hline $\mathrm{CC}-2 \mathrm{~B}$ & $02 / 05 / 03$ & Access hole in cap & 10.87 & 0.00 & 10.87 & 2.21 & 8.66 & $8,877.53$ & $8,868.87$ \\
\hline $\mathrm{CC}-2 \mathrm{~B}$ & $03 / 04 / 03$ & Access hole in cap & 9.68 & 0.00 & 9.68 & 2.21 & 7.47 & $8,877.53$ & $8,870.06$ \\
\hline $\mathrm{CC}-2 \mathrm{~B}$ & $04 / 10 / 03$ & Access hole in cap & 8.63 & 0.00 & 8.63 & 2.21 & 6.42 & $8,877.53$ & $8,871.11$ \\
\hline $\mathrm{CC}-2 \mathrm{~B}$ & 05/06/03 & Access hole in cap & 10.00 & 0.00 & 10.00 & 2.21 & 7.79 & $8,877.53$ & $8,869.74$ \\
\hline $\mathrm{CC}-2 \mathrm{~B}$ & 06/04/03 & Access hole in cap & 9.12 & 0.00 & 9.12 & 2.21 & 6.91 & $8,877.53$ & $8,870.62$ \\
\hline $\mathrm{CC}-2 \mathrm{~B}$ & $07 / 21 / 03$ & Access hole in cap & 10.15 & 0.00 & 10.15 & 2.21 & 7.94 & $8,877.53$ & $8,869.59$ \\
\hline $\mathrm{CC}-2 \mathrm{~B}$ & $08 / 12 / 03$ & Access hole in cap & 9.87 & 0.00 & 9.87 & 2.21 & 7.66 & $8,877.53$ & $8,869.87$ \\
\hline
\end{tabular}


Table 4. Altitude of water levels in Phase I and II wells and existing Advanced Wastewater Treatment Facility wells, Red River Valley, north-central New Mexico, 2002-04.-Continued

[Shaded rows indicate water-level measurements obtained by URS, Denver, Colorado. NGVD 29, National Geodetic Vertical Datum of 1929]

\begin{tabular}{|c|c|c|c|c|c|c|c|c|c|}
\hline $\begin{array}{l}\text { Well } \\
\text { identifi- } \\
\text { cation } \\
\text { (figs. 2-5) }\end{array}$ & $\begin{array}{c}\text { Date } \\
\text { (month/ } \\
\text { day/year) }\end{array}$ & $\begin{array}{l}\text { Measuring point } \\
\text { (permanent } \\
\text { measuring point if } \\
\text { no correction) }\end{array}$ & $\begin{array}{l}\text { Depth to } \\
\text { water } \\
\text { (feet below } \\
\text { measuring } \\
\text { point) }\end{array}$ & $\begin{array}{l}\text { Measu- } \\
\text { ring point } \\
\text { correction } \\
\text { (feet) }^{1}\end{array}$ & $\begin{array}{c}\text { Depth to } \\
\text { water } \\
\text { (feet below } \\
\text { permanent } \\
\text { measuring } \\
\text { point) }\end{array}$ & $\begin{array}{l}\text { Measuring } \\
\text { point height } \\
\text { above land } \\
\text { surface } \\
\text { (feet) }\end{array}$ & $\begin{array}{l}\text { Depth to } \\
\text { water } \\
\text { (feet below } \\
\text { land } \\
\text { surface) }\end{array}$ & $\begin{array}{l}\text { Land } \\
\text { surface } \\
\text { altitude } \\
\text { (feet above } \\
\text { NGVD 29) }\end{array}$ & $\begin{array}{l}\text { Altitude } \\
\text { of water } \\
\text { level (feet } \\
\text { above } \\
\text { NGVD 29) }\end{array}$ \\
\hline \multicolumn{10}{|c|}{ Phase II wells-Continued } \\
\hline $\mathrm{CC}-2 \mathrm{~B}$ & $10 / 22 / 03$ & Access hole in cap & 9.48 & 0.00 & 9.48 & 2.21 & 7.27 & $8,877.53$ & $8,870.26$ \\
\hline $\mathrm{CC}-2 \mathrm{~B}$ & $10 / 23 / 03$ & Access hole in cap & 10.77 & 0.00 & 10.77 & 2.21 & 8.56 & $8,877.53$ & $8,868.97$ \\
\hline $\mathrm{CC}-2 \mathrm{~B}$ & $11 / 04 / 03$ & Access hole in cap & 9.55 & 0.00 & 9.55 & 2.21 & 7.34 & $8,877.53$ & $8,870.19$ \\
\hline
\end{tabular}

\begin{tabular}{|c|c|c|c|c|c|c|c|c|c|}
\hline $\mathrm{CC}-2 \mathrm{~B}$ & $12 / 11 / 03$ & Access hole in cap & 9.60 & 0.00 & 9.60 & 2.21 & 7.39 & $8,877.53$ & $8,870.14$ \\
\hline $\mathrm{CC}-2 \mathrm{~B}$ & 01/07/04 & Access hole in cap & 9.70 & 0.00 & 9.70 & 2.21 & 7.49 & $8,877.53$ & $8,870.04$ \\
\hline $\mathrm{CC}-2 \mathrm{~B}$ & $04 / 21 / 04$ & Access hole in cap & 8.41 & 0.00 & 8.41 & 2.21 & 6.20 & $8,877.53$ & $8,871.33$ \\
\hline
\end{tabular}

Existing Advanced Wastewater Treatment Facility wells

\begin{tabular}{|c|c|c|c|c|c|c|c|c|c|}
\hline AWWT-1 & $03 / 27 / 02$ & Top of casing & 124.68 & 0.00 & 124.68 & 0.50 & 124.18 & $8,523.00$ & $8,398.82$ \\
\hline AWWT-1 & 04/26/02 & Top of casing & 121.95 & 0.00 & 121.95 & 0.50 & 121.45 & $8,523.00$ & $8,401.55$ \\
\hline AWWT-1 & $05 / 23 / 02$ & Top of casing & 121.26 & 0.00 & 121.26 & 0.50 & 120.76 & $8,523.00$ & $8,402.24$ \\
\hline AWWT-1 & $07 / 26 / 02$ & Top of casing & 125.10 & 0.00 & 125.10 & 0.50 & 124.60 & $8,523.00$ & $8,398.40$ \\
\hline AWWT-1 & 09/17/02 & Top of casing & 128.40 & 0.00 & 128.40 & 0.50 & 127.90 & $8,523.00$ & $8,395.10$ \\
\hline AWWT-1 & $10 / 17 / 02$ & Top of casing & 128.29 & 0.00 & 128.29 & 0.50 & 127.79 & $8,523.00$ & $8,395.21$ \\
\hline AWWT-1 & $12 / 11 / 02$ & Top of casing & 128.42 & 0.00 & 128.42 & 0.50 & 127.92 & $8,523.00$ & $8,395.08$ \\
\hline AWWT-1 & $02 / 04 / 03$ & Top of casing & 127.30 & 0.00 & 127.30 & 0.50 & 126.80 & $8,523.00$ & $8,396.20$ \\
\hline AWWT-1 & 07/08/03 & Top of casing & 113.02 & 0.00 & 113.02 & 0.50 & 112.52 & $8,523.00$ & $8,410.48$ \\
\hline AWWT-1 & $08 / 21 / 03$ & Top of casing & 118.37 & 0.00 & 118.37 & 0.50 & 117.87 & $8,523.00$ & $8,405.13$ \\
\hline AWWT-1 & $09 / 18 / 03$ & Top of casing & 120.04 & 0.00 & 120.04 & 0.50 & 119.54 & $8,523.00$ & $8,403.46$ \\
\hline AWWT-1 & $10 / 06 / 03$ & Top of casing & 121.77 & 0.00 & 121.77 & 0.50 & 121.27 & $8,523.00$ & $8,401.73$ \\
\hline AWWT-1 & $10 / 24 / 03$ & Top of casing & 123.50 & 0.00 & 123.50 & 0.50 & 123.00 & $8,523.00$ & $8,400.00$ \\
\hline AWWT-1 & $10 / 31 / 03$ & Top of casing & 123.00 & 0.00 & 123.00 & 0.50 & 122.50 & $8,523.00$ & $8,400.50$ \\
\hline AWWT-1 & $11 / 22 / 03$ & Top of casing & 123.70 & 0.00 & 123.70 & 0.50 & 123.20 & $8,523.00$ & $8,456.80$ \\
\hline
\end{tabular}


Table 4. Altitude of water levels in Phase I and II wells and existing Advanced Wastewater Treatment Facility wells, Red River Valley, north-central New Mexico, 2002-04. - Continued

[Shaded rows indicate water-level measurements obtained by URS, Denver, Colorado. NGVD 29, National Geodetic Vertical Datum of 1929]

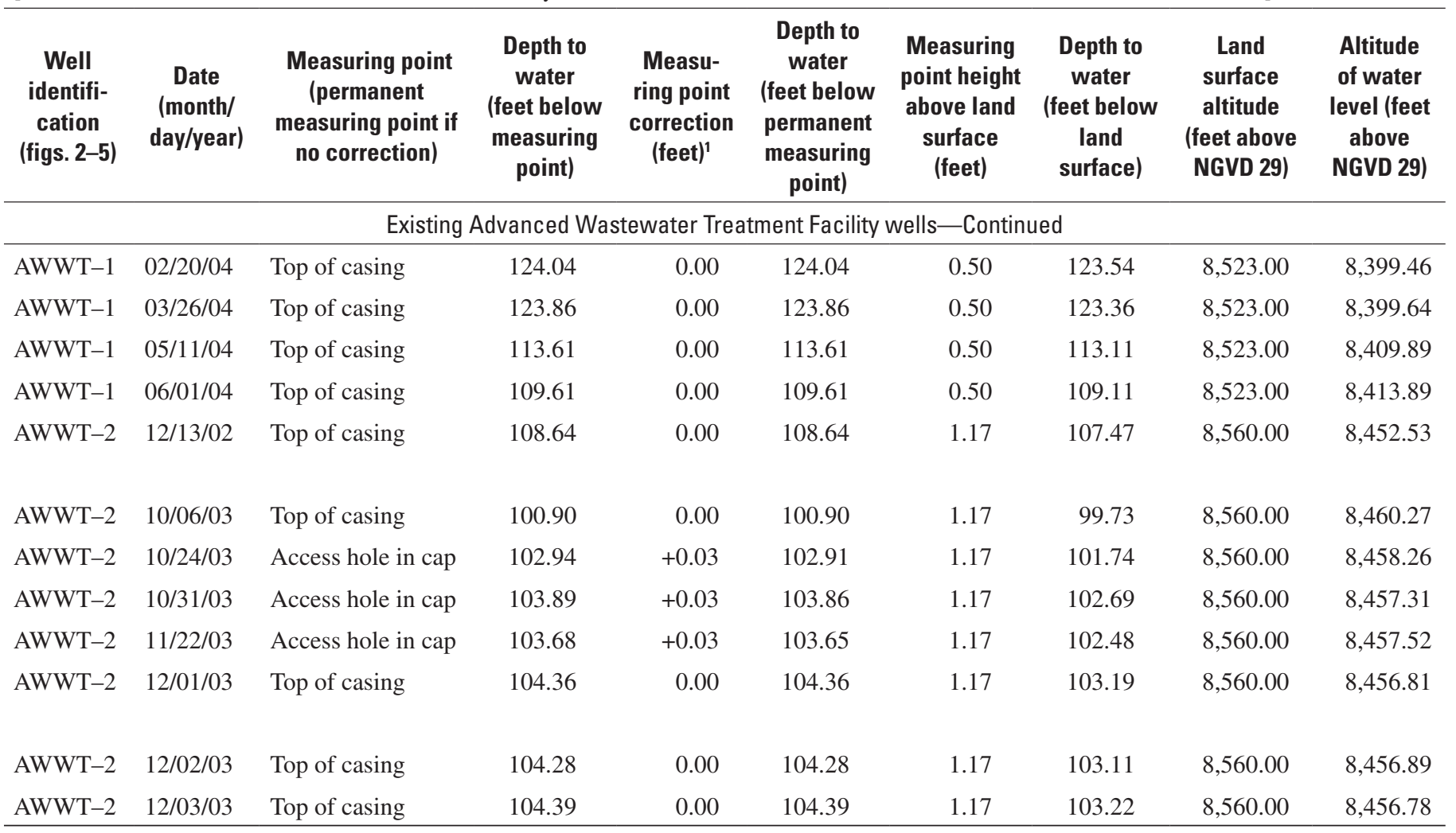

${ }^{1}$ Measuring point correction is distance of measuring point at time of measurement, in feet above (+) or below (-) permanent measuring point.

${ }^{2}$ Depth is measured along the well bore. Well bore was angled 21.5 degrees from vertical.

${ }^{3}$ Calculated vertical distance from measuring point or land surface to water.

Wells 2-1 and 2-2 were installed about $450 \mathrm{ft}$ upstream (east) from a line from the Red River to the La Bobita well (fig. 4). Well 2-1 is adjacent to the north bank of the Red River, and well 2-2 is about $100 \mathrm{ft}$ farther north of the Red River. Wells 2-1 and 2-2 were advanced to 15.97 and $14.37 \mathrm{ft}$ below land surface, respectively, at which depth a

semiconsolidated deposit (possibly ferricrete) was encountered and no further advancement was achieved.

Ground-water levels in wells 2-1 and 2-2 ranged from 30.35 to $35.11 \mathrm{ft}$ higher than concurrently measured water levels in well 1 (table 5). The land surface at wells $2-1$ and $2-2$ is about $20.6 \mathrm{ft}$ higher than at well 1 (table 5). The substantially higher water levels in wells 2-1 and 2-2 relative to those measured concurrently in the La Bobita well and well 1 indicate that the underlying semiconsolidated deposits encountered at total depths of wells $2-1$ and 2-2 are substantially less permeable than the overlying alluvium. Therefore, ground water near wells $2-1$ and $2-2$ is perched by the semiconsolidated deposits encountered during drilling. Water in wells $2-1$ and 2-2 may be disconnected from or have a poor hydraulic connection to ground water present at the La Bobita well and well 1.
Ground-water levels were measured in wells $2-1$ and $2-2$ in May and June 2004. The stage of the Red River also was measured where a line approximately perpendicular to the bank of the river intersects wells $2-1$ and 2-2. Ground-water levels in well 2-1 ranged from about 0.2 to $0.7 \mathrm{ft}$ higher than the stage of the Red River (fig. 14, table 5). Ground-water levels in well 2-2 ranged from about 0.4 to $0.1 \mathrm{ft}$ lower than the stage of the Red River (fig. 14, table 5). Ground-water levels in well $2-1$ were 0.59 and $0.80 \mathrm{ft}$ higher than those in well 2-2. Differences of less than $1 \mathrm{ft}$ between water levels in wells 2-1, 2-2, and the stage of the Red River indicate that there is a substantial hydraulic connection between the ground-water system penetrated by the wells and the Red River surface-water system.

Well 3 was installed about 1,600 ft upstream (east) from wells 2-1 and 2-2 (fig. 4). Ground-water levels measured in well 3 in May and June 2004 ranged from 0.5 to $1.1 \mathrm{ft}$ higher than the stage of the Red River where a line approximately perpendicular to the bank of the river intersects well 3 . These water-level measurements indicate that the Red River and the underlying ground water are hydraulically connected and that ground water has a gradient toward the Red River. 
Table 5. Altitude of water levels in La Bobita and Phase III wells and concurrent altitude of stage of Red River, northcentral New Mexico, 2003-04.

[Permanent measuring point for Phase III wells is top of the 1-inch PVC casing (TOC); NGVD 29, National Geodetic Vertical Datum of 1929; --, no data]

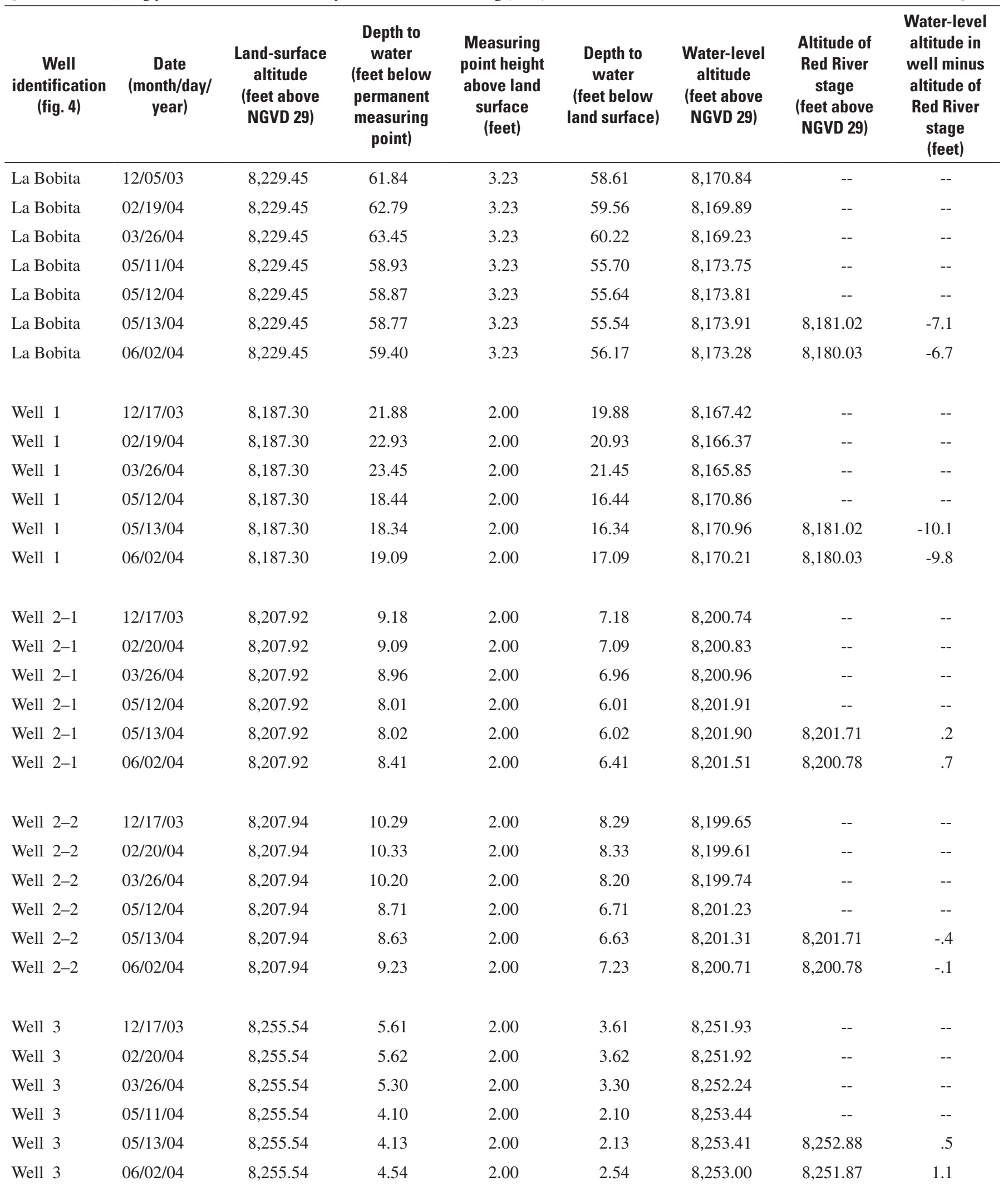


Table 5. Altitude of water levels in La Bobita and Phase III wells and concurrent altitude of stage of Red River, northcentral New Mexico, 2003-04.-Continued

[Permanent measuring point for Phase III wells is top of the 1-inch PVC casing (TOC); NGVD 29, National Geodetic Vertical Datum of 1929; --, no data]

\begin{tabular}{|c|c|c|c|c|c|c|c|c|}
\hline $\begin{array}{c}\text { Well } \\
\text { identification } \\
\text { (fig. 4) }\end{array}$ & $\begin{array}{c}\text { Date } \\
\text { (month/day/ } \\
\text { year) }\end{array}$ & $\begin{array}{l}\text { Land-surface } \\
\text { altitude } \\
\text { (feet above } \\
\text { NGVD 29) }\end{array}$ & $\begin{array}{c}\text { Depth to } \\
\text { water } \\
\text { (feet below } \\
\text { permanent } \\
\text { measuring } \\
\text { point) }\end{array}$ & $\begin{array}{l}\text { Measuring } \\
\text { point height } \\
\text { above land } \\
\text { surface } \\
\text { (feet) }\end{array}$ & $\begin{array}{c}\text { Depth to } \\
\text { water } \\
\text { (feet below } \\
\text { land surface) }\end{array}$ & $\begin{array}{l}\text { Water-level } \\
\text { altitude } \\
\text { (feet above } \\
\text { NGVD 29) }\end{array}$ & $\begin{array}{l}\text { Altitude of } \\
\text { Red River } \\
\text { stage } \\
\text { (feet above } \\
\text { NGVD 29) }\end{array}$ & $\begin{array}{c}\text { Water-level } \\
\text { altitude in } \\
\text { well minus } \\
\text { altitude of } \\
\text { Red River } \\
\text { stage } \\
\text { (feet) }\end{array}$ \\
\hline Well 4-1D & $03 / 26 / 04$ & $8,398.00$ & 8.70 & 2.00 & 6.70 & $8,391.30$ & -- & -- \\
\hline Well 4-1D & 05/11/04 & $8,398.00$ & 6.38 & 2.00 & 4.38 & $8,393.62$ & -- & -- \\
\hline Well 4-1D & 05/13/04 & $8,398.00$ & 6.58 & 2.00 & 4.58 & $8,393.42$ & $8,392.96$ & 0.5 \\
\hline Well 4-1D & 06/02/04 & $8,398.00$ & 6.69 & 2.00 & 4.69 & $8,393.31$ & $8,391.64$ & 1.7 \\
\hline Well 4-1S & $03 / 26 / 04$ & $8,398.10$ & 8.68 & 1.95 & 6.73 & $8,391.37$ & -- & -- \\
\hline Well 4-1S & 05/11/04 & $8,398.10$ & 6.49 & 1.95 & 4.54 & $8,393.56$ & -- & -- \\
\hline Well 4-1S & 05/13/04 & $8,398.10$ & 6.61 & 1.95 & 4.66 & $8,393.44$ & $8,392.96$ & .5 \\
\hline Well 4-1S & 06/02/04 & $8,398.10$ & 6.77 & 1.95 & 4.82 & $8,393.28$ & $8,391.64$ & 1.6 \\
\hline Well 4-2D & $12 / 18 / 03$ & $8,401.95$ & 12.10 & 2.05 & 10.05 & $8,391.90$ & -- & -- \\
\hline Well 4-2D & 02/19/04 & $8,401.95$ & 13.04 & 2.05 & 10.99 & $8,390.96$ & -- & -- \\
\hline Well 4-2D & $03 / 26 / 04$ & $8,401.95$ & 11.50 & 2.05 & 9.45 & $8,392.50$ & -- & -- \\
\hline Well 4-2S & $12 / 18 / 03$ & $8,402.32$ & 12.47 & 2.00 & 10.47 & $8,391.85$ & -- & -- \\
\hline Well 4-2S & 02/19/04 & $8,402.32$ & 13.41 & 2.00 & 11.41 & $8,390.91$ & -- & -- \\
\hline Well 4-2S & $03 / 26 / 04$ & $8,402.32$ & 11.89 & 2.00 & 9.89 & $8,392.43$ & -- & -- \\
\hline Well 4-2S & $05 / 11 / 04$ & $8,402.32$ & 8.40 & 2.00 & 6.40 & $8,395.92$ & -- & -- \\
\hline Well 4-2S & 05/13/04 & $8,402.32$ & 8.70 & 2.00 & 6.70 & $8,395.62$ & $8,394.99$ & .6 \\
\hline Well 4-2S & 06/02/04 & $8,402.32$ & 8.57 & 2.00 & 6.57 & $8,395.75$ & $8,395.27$ & .5 \\
\hline Well 4-2S & 06/03/04 & $8,402.32$ & 8.55 & 2.00 & 6.55 & $8,395.77$ & $8,394.99$ & .8 \\
\hline
\end{tabular}


Table 5. Altitude of water levels in La Bobita and Phase III wells and concurrent altitude of stage of Red River, northcentral New Mexico, 2003-04.-Continued

[Permanent measuring point for Phase III wells is top of the 1-inch PVC casing (TOC); NGVD 29, National Geodetic Vertical Datum of 1929; --, no data]

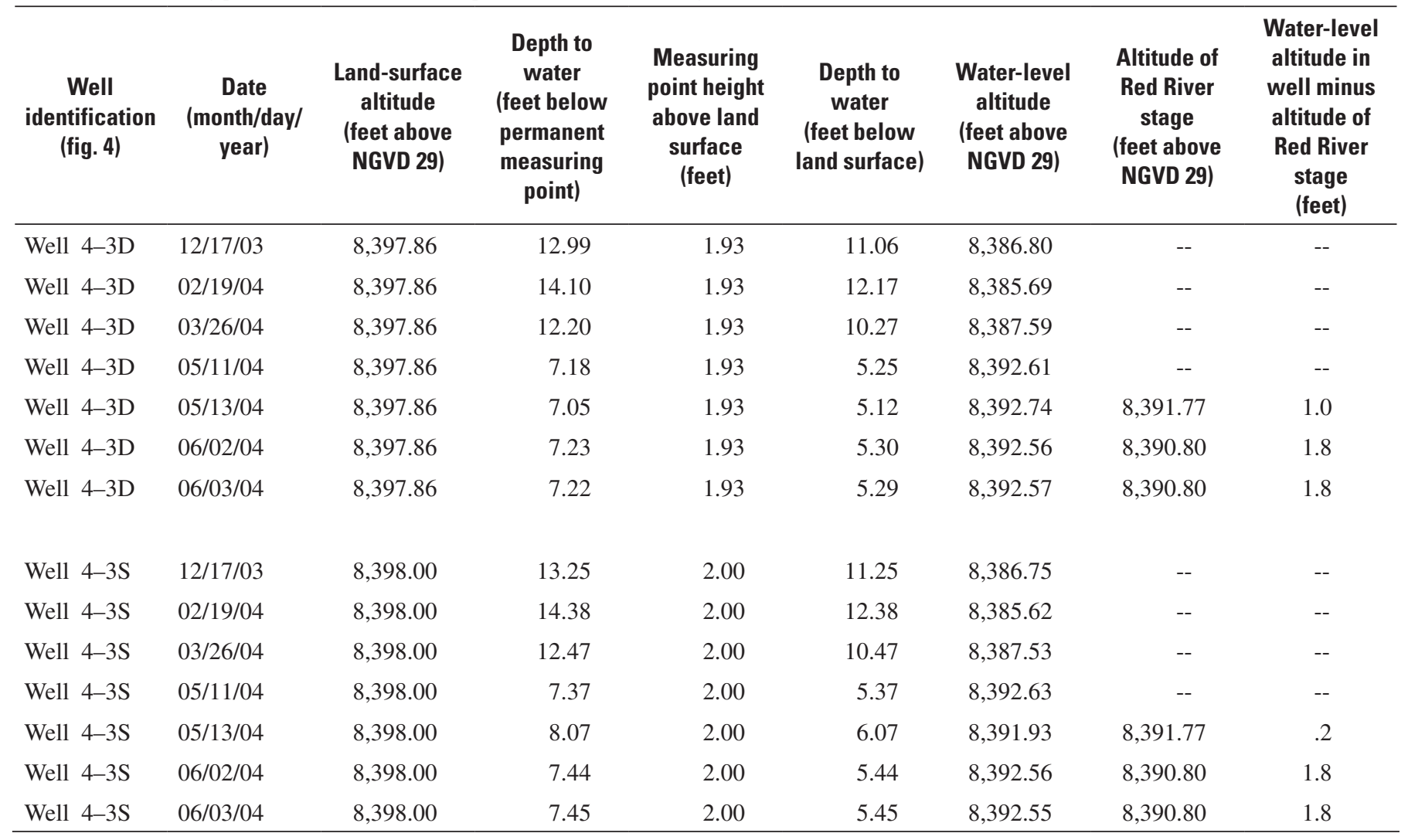

Wells 4-1D, 4-1S, 4-2D, 4-2S, 4-3D and 4-3S were installed between about 3,000 and 3,500 ft upstream (east) from well 3 (fig. 4). Within each of these three pairs of wells, the deeper well (designated with the letter D) was completed at depths ranging from 36.67 to $38.49 \mathrm{ft}$ below land surface; the shallower well (designated with the letter S) was completed at depths ranging from 18.90 to $19.04 \mathrm{ft}$ below land surface.

Ground-water levels measured in all six wells in May and June 2004 ranged from 0.2 to $1.0 \mathrm{ft}$ higher in May 2004 and 0.8 to $1.8 \mathrm{ft}$ higher in June 2004 than the stage of the Red River where lines approximately perpendicular to the bank of the river intersect each of the three pairs of wells. These water-level measurements indicate that the Red River and the underlying ground water are hydraulically connected and that ground water has a gradient toward the Red River.

From December 12, 2003 through June 2, 2004, groundwater levels in well 4-1S ranged from $0.07 \mathrm{ft}$ higher to $0.06 \mathrm{ft}$ lower than concurrently measured water levels in well 4-1D (table 5). During the same period, ground-water levels in well 4-2S ranged from 0.05 to $0.42 \mathrm{ft}$ lower than concurrently measured water levels in well 4-2D, and water levels in well 4-3S ranged from $0.02 \mathrm{ft}$ higher to $0.81 \mathrm{ft}$ lower than concurrently measured water levels in well 4-3D (table 5). At the well 4-1 pair, the differences in concurrently measured water levels indicate neither a substantial upward nor a substantial downward vertical component of ground-water flow. At the well 4-2 pair, the differences in concurrently measured water levels indicate that an upward vertical component was present and was greater during the spring snowmelt in May and June. At the well 4-3 pair, the differences in concurrently measured water levels indicate that neither a substantial upward nor a substantial downward vertical component of ground-water flow was present except on May 13, 2004, when an upward gradient was present and was about 10 times larger than during any other of the concurrent measurements.

Within the reach of the Red River adjacent to the La Bobita well and the Phase III wells, the Red River and the shallow ground-water system appear to be hydraulically connected from the upstream part of this reach near wells 4-1D and 4-1S downstream to near wells 2-1 and 2-2. Between wells 2-1 and 2-2 and the La Bobita well and well 1, however, the nature of this connection changes, and these systems are no longer hydraulically connected or are poorly connected near the La Bobita well and well 1. 


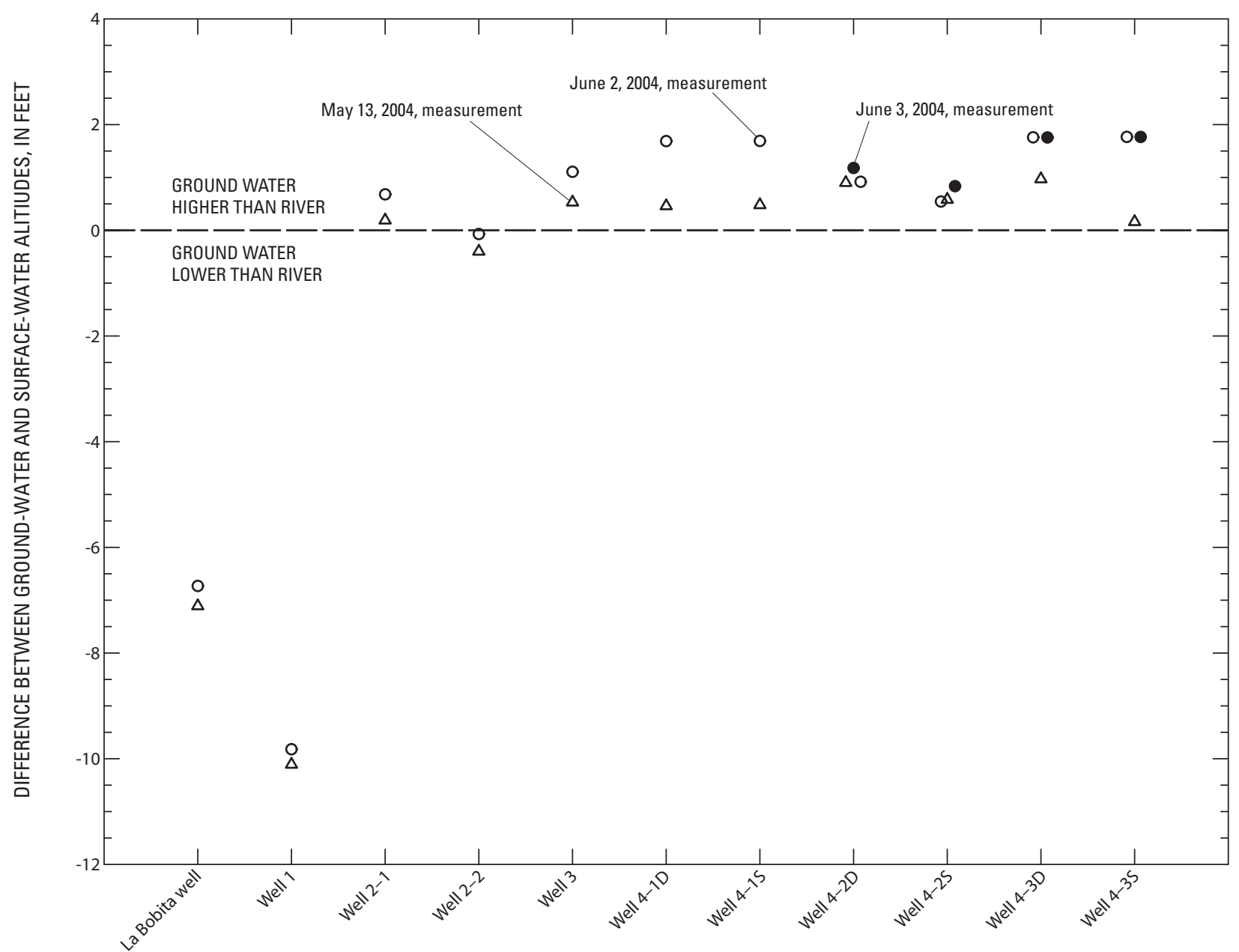

Figure 14. Difference between ground-water altitudes in La Bobita and Phase III wells and altitude of water in Red River, May 13 and June 2-3, 2004

\section{Summary}

In April 2001, the U.S. Geological Survey (USGS) and the New Mexico Environment Department began a cooperative study to infer the pre-mining ground-water chemistry at the Molycorp molybdenum mine site in the Red River Valley, north-central New Mexico. The Molycorp molybdenum mine has operated intermittently since the 1920s; ground-waterlevel and water-quality data were not obtained prior to initiation of mining. To infer pre-mining ground-water chemistry, wells were drilled in five unmined areas geologically analogous to the mined area-Hottentot Creek, Straight Creek, Hansen Creek, near La Bobita campground, and Capulin Canyon.

The purpose of this report is to document and describe Phase II and Phase III well installation and development, present results of lithologic and geophysical logging, present results of hydraulic testing to determine aquifer characteristics, and present and discuss water-level measurements collected during the period March 2002 to June 2004. This report is one in a series of reports that can be used to determine pre-mining ground-water conditions at the mine site.

The main area of study within the Red River drainage basin extends west from the town of Red River to the USGS streamflow-gaging station near Questa (Questa gage). The area upstream from the Questa gage includes approximately $18 \mathrm{mi}$ of the Red River and $108 \mathrm{mi}^{2}$ of the Red River drainage basin. Weathering of hydrothermally altered bedrock in the study area has resulted in steep, highly erosive, and sparsely vegetated scar areas that are clearly visible from the ground and in aerial photographs. Runoff from intense summer rainfall over basins tributary to the Red River can transport large quantities of sediment down tributary drainages and form debris fans where these tributaries join the Red River. Where the tributary drainages contain scar areas, the debris fans are large and indicate evidence of active deposition. Large debris fans debouching from tributary drainages have caused aggradation of the Red River streambed in river reaches upstream from debris fans.

Important water-bearing units in the Red River Valley include fractured bedrock, debris-flow deposits, and Red River 
alluvium. Debris-flow deposits, debris fans, and Red River alluvium are smaller in area but contain most of the ground water in the valley. Debris-flow deposits, debris fans, and the Red River alluvium typically are less than 1,000 ft wide and less than $200 \mathrm{ft}$ thick.

Twenty-nine observation wells were installed in three phases as part of this study in the Red River Valley and tributary drainages. Phase I wells (SC-1 A and B, SC-2B, SC-3A and $\mathrm{B}, \mathrm{SC}-4 \mathrm{~A}, \mathrm{SC}-5 \mathrm{~A}$ and $\mathrm{B}$ ) were located in the Straight Creek drainage basin along the assumed path of ground-water flow in debris-flow deposits from the upstream part of the basin to near the mouth of the basin, where Straight Creek flows into Red River. Phase II well SC-6A was installed in the Straight Creek drainage, wells SC-7A and SC-8A were installed in Red River alluvial deposits west of Straight Creek, and well SC-9A was installed on the north bank of Red River to complete the series of wells in the Straight Creek drainage basin. Phase II wells also were installed in the Hottentot, Hansen, and La Bobita drainages and in Capulin Canyon. Phase III wells were installed in unconsolidated material along an approximately 1-mi reach of the Red River west of Elephant Rock campground.

Eight Phase II observation wells (Hottentot, SC-6A, SC-7A, SC-8A, Hansen, La Bobita, CC-1B and CC-2B) were drilled using an air-rotary/hammer rig equipped with a casing-advance system. The casing-advance system temporarily cased the holes ensuring that the holes did not collapse. Each well was constructed using flush-threaded, 4-in. diameter, schedule-80 polyvinyl chloride (PVC) casing and factorycut, 0.010-in. slot size PVC screen. Three Phase II smalldiameter wells were installed using a direct-push rig. Wells $\mathrm{CC}-1 \mathrm{~A}$ and $\mathrm{CC}-2 \mathrm{~A}$ were installed in Capulin Canyon next to the air-rotary-drilled wells $\mathrm{CC}-1 \mathrm{~B}$ and $\mathrm{CC}-2 \mathrm{~B}$, respectively. Well SC-9A was installed at the mouth of the Straight Creek and was advanced under the Red River at an angle of 21.5 degrees from vertical to a total angular depth of $22.5 \mathrm{ft}$. The Phase II small-diameter wells (CC-1A, CC-2A, and SC-9A) were constructed of 1-in. diameter schedule $40 \mathrm{PVC}$ with a 5-ft long screen at the total depth of the hole.

Ten Phase III small-diameter observation wells were installed using a direct-push rig along an approximately 1-mi reach of the Red River west of Elephant Rock. Each well was constructed of 1-in. diameter schedule 40 PVC casing and a 5 -ft screen at the total depth of the hole.

Lithologic logs were recorded for all eight Phase II drilled wells. Borehole geophysical logging was conducted in Phase II wells SC-6A, SC-7A, and SC-8A. Lithologic logs were constructed from examination of borehole cuttings. Cuttings were collected at 5-ft intervals from land surface to total depth. Natural gamma, induction, and single-detector neutron geophysical logging were conducted in wells SC-6A, SC-7A, and SC-8A during February 2003 following well completion and development.

In well SC-6A, the geophysical logs indicate that the deposits about $11 \mathrm{ft}$ above the water table were dry. The lithologic log, however, indicates that the cuttings retrieved from this interval were wet. This inconsistency between the lithologic log and the geophysical log interpretation indicates that the change in the geophysical log may be related to geologic conditions rather than a lack of moisture. For well SC-7A, geophysical logs suggest that the deposits above the water table were dry to partially saturated. For well SC-8A, geophysical logs indicate that deposits were partially saturated at about $70 \mathrm{ft}$ below land surface. Induction and gamma logs from 60 to $69 \mathrm{ft}$ correspond to the presence of gravelsized deposits described in the driller's log. The neutron log indicates that porosity decreases with depth over the screened interval.

Aquifer tests conducted during 2003 to estimate the hydraulic properties of debris-flow deposits and Red River alluvial deposits in and near Straight Creek included a flowmeter survey, slug tests, and a pumping test. A flow-meter survey was conducted in well SC-7A on October 27, 2003, using a flow meter that was lowered to about $150 \mathrm{ft}$ and a pump that was lowered to about $10 \mathrm{ft}$ below the static water level. The well was pumped at a rate of $3.64 \mathrm{gal} / \mathrm{min}$, and drawdown in the well reached steady state at $0.07 \mathrm{ft}$ below the static water level. Results of the flow-meter survey indicated that about 77 percent of the water entered the well from a 10-ft-thick zone near the top of the screened interval and about 23 percent of the water entered the well from a 15 -ft-thick zone near the bottom of the screened interval.

Slug tests were performed in wells SC-1A, SC-1B, SC-2B, SC-3A, SC-3B, SC-4A, SC-5A, SC-5B, SC-6A, SC-7A, and SC-8A during June 3-5, 2003. Water-level data were recorded during each slug test using a submersible pressure transducer connected to a data logger. For wells with screens in debris-flow deposits (wells SC-1A, SC-3A, $\mathrm{SC}-4 \mathrm{~A}$, and SC-6A), the mean and median estimated hydraulic conductivities were 15.25 and $15.35 \mathrm{ft} / \mathrm{d}$, respectively. For wells with screens in bedrock (wells SC-1B, SC-2B, $\mathrm{SC}-3 \mathrm{~B}$, and $\mathrm{SC}-5 \mathrm{~B}$ ), the mean and median estimated hydraulic conductivities were 0.12 and $0.08 \mathrm{ft} / \mathrm{d}$, respectively. For wells with screens in mixed debris-flow deposits and Red River alluvium (wells SC-5A, SC-7A, and SC-8A), the mean and median estimated hydraulic conductivities were 73-207 (estimated range) and $80 \mathrm{ft} / \mathrm{d}$. In general, bedrock has the smallest hydraulic conductivity, debris-flow deposits have the next highest hydraulic conductivity, and the mixed debris-flow deposits and Red River alluvium have the largest hydraulic conductivity.

A pumping test was conducted December 3-4, 2003, on well AWWT-1 as the pumped well and wells AWWT-2, SC-5A, SC-5B, SC-7A, and SC-8A as observation wells. The time-weighted average pumping rate was $106 \mathrm{gal} / \mathrm{min}$. Analysis of the pumping test water-level data indicated estimated transmissivity of 12,000 to $34,000 \mathrm{ft}^{2} / \mathrm{d}$ and estimated hydraulic conductivity of 230 to $340 \mathrm{ft} / \mathrm{d}$.

Water-level measurements in wells SC-6A, SC-7A, SC-8A, and the Hottentot, Hansen, and La Bobita wells show that water levels typically rose rapidly during the time of melting of the winter snowpack in the spring and then generally 
declined during the rest of the year. The duration of waterlevel rise, however, appears to be typically about 2 months, after which a slow water-level decline occurs during the following 10 months. In the Straight Creek drainage, the waterlevel rise in response to spring snowmelt occurred earlier and was smaller at greater distances from the Red River. The spring increases in water levels in wells SC7-A and SC-8A were about eight times larger than those in well SC-6A.

Well SC-9A was dry at the time of construction but subsequently contained water. Differences between the stage in the Red River and water levels in wells SC-8A and SC-9A, and the absence of water in well SC-9A at its time of completion, indicate that the Red River had a poor hydraulic connection to the underlying ground-water system and the surfacewater system is perched above the ground-water system at this site.

Water levels in Phase III wells indicate that the Red River and the shallow ground-water system appear to be hydraulically connected from near wells 4-1D and 4-1S downstream to near wells $2-1$ and 2-2. Between wells $2-1$ and 2-2 and the La Bobita well and well 1, however, the nature of this connection changes, and these systems are no longer hydraulically connected or are poorly connected in the vicinity of the La Bobita well and well 1.

\section{References}

Bouwer, Herman, and Rice, R.C., 1976, A slug test for determining hydraulic conductivity of unconfined aquifers with completely or partially penetrating wells: Water Resources Research, v. 12, no. 3, p. 423-428.

Caine, J.S., 2003, Questa baseline and pre-mining groundwater quality investigation 6.-Preliminary brittle structural geologic data, Questa mining district, southern Sangre de Cristo Mountains, New Mexico: U.S. Geological Survey Open-File Report 03-280, 24 p.

Cooper, H.H., and Jacob, C.E., 1946, A generalized graphical method for evaluating formation constants and summarizing well field history: American Geophysical Union Transactions, v. 27, p. 526-534.

Duffield, G.M., 2000, AQTESOLV for Windows user's guide: Reston, Virginia, Hydrosolve, Inc., July 24, 2000, 164 p.

Gale, V.G., and Thompson, A.J.B., 2001, Reconnaissance study of waste rock mineralogy-Questa, New Mexico, Petrography, PIMA Spectral Analysis and Rietveld Analysis: Vancouver British Columbia, Petra-Science Consultants, Inc., January 31, variously paged.

Halford, K.J., and Kuniansky, E.L., 2002, Documentation of spreadsheets for the analysis of aquifer-test and slug-test data: U.S. Geological Survey Open-File Report 02-197, $51 \mathrm{p}$.
Hearst, J.R., Nelson, P.H., and Paillet, F.L., 2000, Well logging for physical properties (2nd ed.): New York, John Wiley and Sons, 483 p.

Jorgensen, D.G., 1991, Estimating geohydrologic properties from borehole geophysical logs: Ground Water Monitoring and Remediation, v. 10, no. 2, p. 123-129.

Keys, W.S., 1986, Analysis of geophysical logs of water wells with a microcomputer: Ground Water, v. 24, no. 6, p. 750 760 .

Keys, W.S., 1990, Borehole geophysics applied to ground water investigations: U.S. Geological Survey Techniques of Water-Resources Investigations, book 2, chap E2, 150 p.

Knight, P.J., 1990, The flora of the Sangre de Cristo Mountains, New Mexico, in Bauer, P.W., Lucas, S.G., Mawer, C.K., and McIntosh, W.C., eds., Tectonic development of the southern Sangre de Cristo Mountains, New Mexico: New Mexico Geological Society 41st Annual Field Conference, September 12-15 Guidebook, p. 94-95.

Lipman, P.W., 1981, Volcano-tectonic setting of tertiary ore deposits, southern Rocky Mountains: Arizona Geological Society Digest, v. 14, p. 199-213.

Ludington, Steve, Plumlee, Geoff, Caine, Jonathan, Bove, Dana, Holloway, JoAnn, and Livo, Eric, 2005, Questa baseline and pre-mining groundwater quality investigation 10.-Geologic influences on ground and surface waters in the lower Red River watershed, New Mexico: U.S. Geological Survey Scientific Investigations Report 2004-5245, $41 \mathrm{p}$.

McCleskey, R.B., Nordstrom, D.K., Steiger, J.I., Kimball, B.A., and Verplanck, P.L., 2003, Questa baseline and premining ground-water quality investigation 2.-Low-flow (2001) and snowmelt (2002) synoptic/tracer water chemistry for the Red River, New Mexico: U.S. Geological Survey Open-File Report 03-148, 166 p.

Meyer, J.W., and Leonardson, R.W., 1990, Tectonic, hydrothermal and geomorphic controls on alteration scar formation near Questa, New Mexico: Socorro, New Mexico Geological Society, 41st Field Conference Guidebook, p. 417-422.

Meyer, J.W., and Leonardson, R.W., 1997, Geology of the Questa Mining District_-volcanic, plutonic, tectonic and hydrothermal history: New Mexico Bureau of Geology and Mineral Resources, Open-File Report 431, 187 p.

Molycorp, Inc., 2004, Molybdenum, Questa, New Mexicohistory: Information available on Web, accessed July 22, 2004, at http://www.molycorp.com/home_frameset.html 
Naus, C.A., McCleskey, R.B., Nordstrom, D.K., Donohoe, L.C., Hunt, A.G., Paillet, F.L., Morin, R.H., and Verplanck, P.L., 2005, Questa baseline and pre-mining ground-water quality investigation 5.-Well installation, water-level data, and surface- and ground-water geochemistry in the Straight Creek drainage basin, Red River Valley, New Mexico, 2001-2003: U.S. Geological Survey Scientific Investigations Report 2005-5088, 220 p.

Paillet, F.L., and Crowder, R.E., 1996, A generalized approach for the interpretation of geophysical well logs in ground water studies - theory and application: Ground Water, v. 34, no. 5, p. 883-898.

Rehrig, W.A., 1969, Fracturing and its effects on molybdenum mineralization at Questa, New Mexico: Tucson, University of Arizona, Ph.D. dissertation, 194 p.

Robertson GeoConsultants, Inc. (RGC), 2000a, Interim background characterization study, Questa Mine, New Mexico: Report 052008/6, June, 33 p.

Robertson GeoConsultants, Inc. (RGC), 2000b, Interim mine site characterization study, Questa Mine, New Mexico: Report 052008/10, November, 77 p.

Robertson GeoConsultants, Inc. (RGC), 2000c, Progress Report-Questa mine rock pile monitoring and characterization study: Report 052008/7, March, 23 p.

Robertson GeoConsultants, Inc., 2001, Background study data report, Questa Mine, New Mexico: Report 052008/12, prepared for Molycorp, Inc., $40 \mathrm{p}$.

Schilling, J.H., 1956, Geology of the Questa molybdenum mine area, Taos County, New Mexico: New Mexico Bureau of Mines and Mineral Resources, Bulletin 51, 87 p.

Slifer, Dennis, 1996, Red River groundwater investigation, final report: New Mexico Environment Department, Surface Water Quality Bureau, March, 26 p.

Smolka, L.R., and Tague, D.F., 1989, Intensive water quality survey of the Middle Red River, Taos County, New Mexico, September 12-October 25, 1988: New Mexico Environmental Improvement Division, Surveillance and Standards Section, Surface Water Quality Bureau, May 1989, 87 p.

Souder, Miller, and Associates, 2003, Phase II. Drilling summary report-Questa Mine area, New Mexico: Santa Fe, New Mexico, Souder, Miller, and Associates, March 2003, variously paged.
South Pass Resources, Inc., 1995, Supplemental report-discussion of the geology, hydrology, and water quality of the mine area, Molycorp Facility, Taos County, New Mexico: Scottsdale, Arizona, February 15, 15 p.

Steffen Robertson \& Kirsten, 1995, Questa molybdenum mine geochemical assessment: Lakewood, Colorado., SRK Project no. 09206, April 13, 44 p.

Theis, C.V., 1935, Relation between lowering the piezometric surface and the rate and duration of discharge of a well using ground-water storage: American Geophysical Union Transaction, v. 16, p. 519-524.

URS, 2001, Final report, Molycorp, Inc., Questa Mine sitewide comprehensive hydrologic characterization report: Denver, Colorado, March, 95 p.

URS, 2002, Molycorp, Inc., Remedial Investigation/Feasibility Study (RI/FS) work plan, sections one through three, v. 1, draft final: Denver, Colorado, July, variously paged.

U.S. Department of Agriculture Forest Service, 2001, Wildland urban interface areas in USDA FS Southwestern Region: Southwestern Region GIS Datasets, accessed July 22, 2004, at http://www.fs.fed.us/r3/gis/ datasets.shtml\#regional

U.S. Environmental Protection Agency, 2000, NPL site narrative for Molycorp, Inc.: Information available on Web, accessed July 22, 2004, at http://www.epa.gov/ superfund/sites/npl/nar1599.htm

U.S. Geological Survey, 2004, Daily streamflow for the Nation, USGS 08265000 Red River near Questa, New Mexico: Information available on Web, accessed July 22, 2004, at http://nwis.waterdata.usgs.gov/nwis/discharged

Vail Engineering, Inc., 1989, A geochemical investigation of the origin of aluminum hydroxide precipitate in the Red River, Taos County, New Mexico: Santa Fe, New Mexico, June, 43 p.

van der Kamp, Garth, 1976, Determining aquifer transmissivity by means of well response tests- the underdamped case: Water Resources Research, v. 12, no. 1, p. 71-77.

Western Regional Climate Center, 2003, Historical climate information-New Mexico climate summaries, Red River, New Mexico (297323): Information available on Web, accessed July 17, 2003, at http://www.wrcc.dri.edu/ 


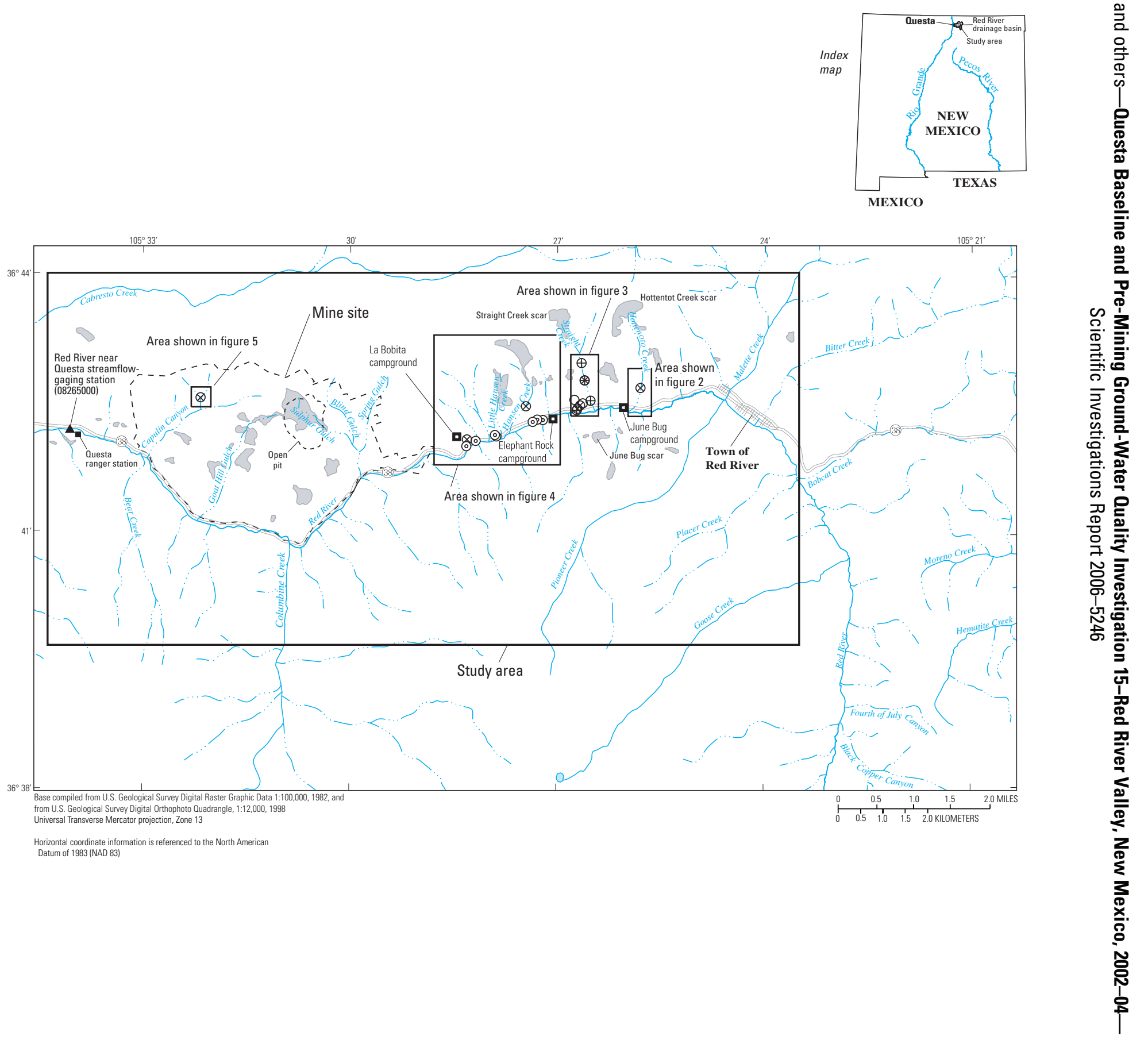

